ANDREW HYNES SERIES:

TECTONIC PROCESSES

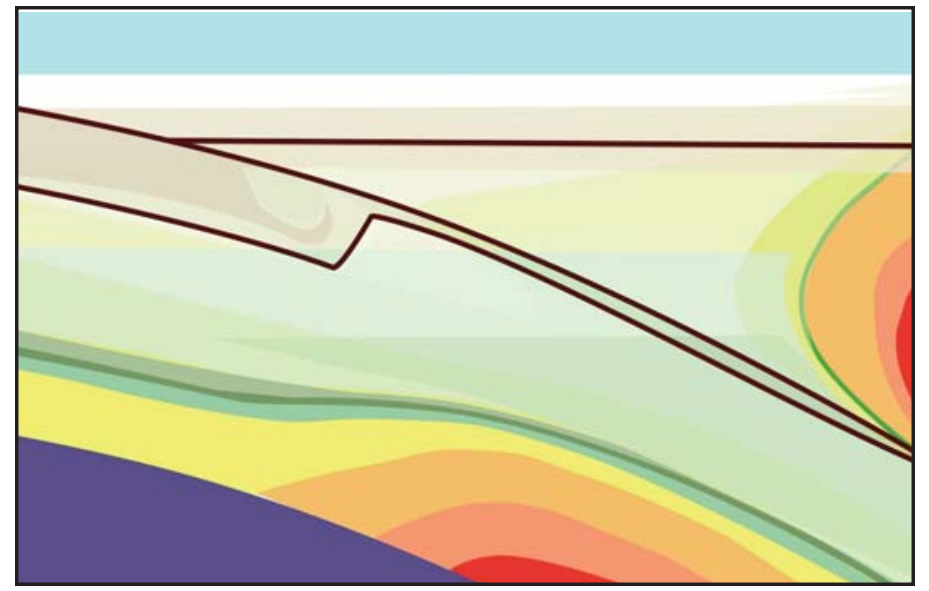

\section{Post-peak Evolution of the Muskoka Domain, Western Grenville Province: Ductile Detachment Zone in a Crustal- scale Metamorphic Core Complex}

\section{Toby Rivers ${ }^{1}$ and Walfried Schwerdtner ${ }^{2}$}

${ }^{1}$ Department of Earth Sciences

Memorial University

St. John's, Newfoundland and Labrador, A1B 3X5, Canada

Email:trivers@mun.ca

${ }^{2}$ Department of Earth Sciences

University of Toronto

22 Russell Street

Toronto, Ontario, M5S 3B1, Canada

\section{SUMMARY}

The Ottawa River Gneiss Complex (ORGC) in the western Grenville Province of Ontario and Quebec is interpreted as the exhumed mid-crustal core of a large metamorphic core complex. This paper concerns the post-peak evolution of the Muskoka domain, the highest structural level in the southern ORGC that is largely composed of amphibolite-facies straight gneiss derived from retrogressed granulite-facies precursors. It is argued that retrogression and high strain occurred during orogenic collapse and that the Muskoka domain acted as the ductile detachment zone between two stronger crustal units, the underlying granulite-facies core known as the Algonquin domain and the overlying lower grade cover comprising the Composite Arc Belt. Formation of the metamorphic core complex followed Ottawan crustal thickening, peak metamorphism and possible channel flow, and took place in a regime of crustal thinning and gravitational collapse in which the cool brittle-ductile upper crust underwent megaboudinage and the underlying hot ductile mid crust flowed into the intervening megaboudin neck regions. Post-peak crustal thinning in the Muskoka domain began under suprasolidus conditions, was facilitated by widespread retrogression, and was heterogeneous, perhaps attaining $~ 90 \%$ locally. It was associated with a range of ductile, high-temperature extensional structures including multi-order boudinage and associated extensional bending folds, and a regional system of extension-dominated transtensional cross-folds. These ductile structures were followed by brittle-ductile fault propagation folding at higher crustal level after the gneiss complex was substantially exhumed and cooled. Collectively the data record $\sim 60$ m.y. of post-peak extension on the margin of an exceptionally large metamorphic core complex in which the ductile detachment zone has a true thickness of $\sim 7 \mathrm{~km}$. The large scale of the core complex is consistent with the deep level of erosion, and the long duration of extensional collapse is compatible with double thickness crust at the metamorphic peak, the presence of abundant leucosome in the mid crust and widespread fluidfluxed retrogression, collectively pointing to the important role of core complexes in crustal cooling after the peak of the Grenvillian Orogeny.

\section{RÉSUMÉ}

Le complexe gneissique de la rivière des Outaouais (ORGC) dans la portion ouest de la Province de Grenville au Québec et en Ontario est interprété comme le cœur d'un grand complexe métamorphique à coeur de noyau. Le présent article porte sur l'évolution post-pic du domaine de Muskoka, soit le niveau structural le plus élevé de l'ORGC composé en grande partie d'orthogneiss au faciès amphibolite dérivés de précurseurs au faciès granulite. Nous soutenons que la rétromorphose et les grandes déformations se sont produites durant l'effondrement orogénique et que le domaine de Muskoka en a été une zone de détachement ductile entre deux unités crustales plus résistantes, le cœur au faciès granulite sous-jacent étant le domaine Algonquin, et la chapeau sus-jacent à plus faible grade de métamorphisme comprenant le Ceinture d'Arc Composite. La for- 
mation du complexe métamorphique à coeur de noyau est survenue après l'épaississement crustale ottavien, le pic métamorphique et le possible flux en chenal, et s'est produit en régime d'amincissement crustal et d'effondrement gravitationnel au cours duquel la croûte supérieure refroidie a subit un mégaboudinage et où la croûte moyenne chaude et ductile sous-jacente a flué dans les régions entre les mégaboudins. L'amincissement crustale post-pic dans le domaine de Muskoka, qui a débuté en conditions suprasolidus, a été facilité par une rétromorphose généralisée, hétérogène, atteignant à peu près $90 \%$ par endroits. Celle-ci a été associée avec une gamme de structures d'extension ductiles de haute température, incluant du boudinage de plusieurs ordres de grandeur et de plis de flexure d'extension, ainsi qu'un système régional de plis croisés d'origine transtensionnelle. À ces structures ductiles a succédé une phase de plissement de propagation de failles cassantes à ductiles à un plus haut niveau crustal, après que le complexe gneissique ait été exhumé et se soit refroidi. Prises ensemble, les données indiquent une extension post-pic sur la marge d'un complexe métamorphique à coeur de noyau exceptionnellement grand aux environs de 60 m.y. et dans laquelle la zone de détachement montre une épaisseur véritable d'environ $7 \mathrm{~km}$. La grandeur de l'échelle du complexe métamorphique à coeur de noyau concorde avec le fort niveau d'érosion, et la grande durée de l'effondrement d'extension est compatible avec une croûte de double épaisseur au pic de métamorphisme, la présence de leucosomes abondants dans la croûte moyenne et d'une rétromorphose à flux fluidique généralisée, l'ensemble indiquant l'importance du rôle des complexes métamorphiques à coeur de noyau dans le refroidissement de la croûte après le pic de l'orogenèse grenvillienne.

Traduit par le Traducteur

\section{INTRODUCTION}

\section{Metamorphic Core Complexes}

Metamorphic core complexes consist of exhumed high-grade deep crust (the metamorphic core) surrounded by lower-grade or unmetamorphosed shallower crust (the cover or carapace) separated by ductile low-angle extensional detachment faults or shear zones. First recognized and defined in a continental arc setting (the North American Cordillera, e.g. Coney 1974, 1980; Lister and Davis 1989) as high-level, relatively small elliptical structures a few tens of $\mathrm{km}$ long by a few $\mathrm{km}$ wide, more recent work has led to the identification of deeper, much larger bodies (e.g. Shuswap complex; Vanderhaeghe et al. 1999, 2003) and to examples from collisional settings (e.g. the Variscan Massif Central, Malavieille et al. 1990; the Caledonian Western Gneiss Region, Krabbendam and Dewey 1998; Cycladic, Carpathian, and Anatolian segments of the Alpine Orogen, Janák et al. 2001; Whitney et al. 2007; Thomson et al. 2009; Kruckenberg et al. 2011), and the Iranian Plateau of the Arabia-Eurasia collisional orogen (Kargaranbafghi and Neubauer 2015). The original definition of a metamorphic core complex was based on Cordilleran examples, but in a recent review the definition was generalized to accommodate features of those formed at deep crustal levels and in other tectonic settings, as follows: " $A$ [metamorphic] core complex is a domal or arched geologic structure composed of ductilely deformed rocks and associated intrusions underlying a ductile-to-brittle bigh-strain zone that experienced tens of kilometers of normal-sense displacement in response to lithospheric extension" (Whitney et al. 2013, p. 274). Moreover, although originally observed in continental crust, comparable structures are now also known in oceanic crust, leading to the understanding that core complexes are a signature of crustal-scale extension and thinning in a wide range of settings, and that they may have played a significant role in crustal cooling and the thermal evolution of Earth. Metamorphic core complexes are distinguished from gneiss domes, with which they may be associated, by crustal thinning resulting from the extensional setting, presence of the detachment zone, and the subordinate role of diapirically driven magmatic flow (e.g. Teyssier and Whitney 2002).

The crustal-scale architecture of core complexes, in which the hot deep crust and cool shallow crust are juxtaposed across the extensional detachment, implies important crustal attenuation and hence the transfer of material and heat from deep to shallower crustal levels, with the potential to drive enhanced fluid flow. The processes of heat and fluid transfer tend to weaken the crust, inducing a positive feedback loop that may influence the magnitude of extension (Whitney et al. 2013). In continental settings, metamorphic core complexes typically develop by collapse of overthickened crust during orogeny (e.g. Rey et al. 2001; Teyssier and Whitney 2002). Insight into the roles of factors that determine their final architecture, including the total amount of extension, the extension rate, the temperature in the mid crust, and the role of melt weakening, have been investigated in numerical modelling experiments (e.g. Rey et al. 2001, 2009; Teyssier and Whitney 2002; Vanderhaeghe 2009; Whitney et al. 2013), and in core complexes from tectonically active orogens (e.g. Kargaranbafghi and Neubauer 2015), leading to more informed interpretations in ancient examples. For instance, the detachment zones above many shallow Cordilleran metamorphic core complexes are narrow greenschist-facies mylonite zones up to a few metres wide, whereas in the larger deeper examples the detachment zones may be from several hundred metres to $2 \mathrm{~km}$ or more wide and composed of amphibolite-facies rocks.

This paper concerns the southwest margin of a very large Precambrian metamorphic core complex, the Ottawa River Gneiss Complex (formerly Central Gneiss Belt; Schwerdtner et al. submitted) situated in the western Grenville Province in Ontario and western Quebec, the exposed part of which has a surface area $>60,000 \mathrm{~km}^{2}$. The identification of metamorphic core complexes in the Grenville Province is quite recent (Rivers 2012, 2015) and many details of their evolution remain poorly constrained. In this contribution, we focus on field evidence relating to the post-peak structural and metamorphic evolution of the southern part of the Ontario segment of the Ottawa River Gneiss Complex where the Muskoka domain structurally overlies the Algonquin domain, particularly the identification of the detachment zone and the manifestation, scale, and duration of extension recorded on it.

\section{Definition and Large-scale Architecture of the Ottawa River Gneiss Complex}

The new name Ottawa River Gneiss Complex (ORGC) was proposed by Schwerdtner et al. (submitted) for the large area of high-grade rocks in the western Grenville Province of Ontario and western Quebec between the Grenville Front 
Tectonic Zone and the Composite Arc and Frontenac-Adirondack belts, previously termed the Central Gneiss Belt by Wynne-Edwards (1972). At the time of its original naming, the gneiss complex was not well studied and was principally defined by its gneissic character and upper amphibolite- to granulite-facies assemblages that were inferred to be the depositional basement to the non-gneissic, lower grade (greenschist- to amphibolite-facies) rocks of supracrustal origin in the adjacent 'Central Metasedimentary Belt' (later Composite Arc Belt) to the southeast. The new name is proposed in order to make a formal break with the original nomenclature and acknowledge the significant evolution in understanding since it was applied (see below and Schwerdtner et al. submitted).

The first attempts at internal subdivision of what we term the ORGC were made in the Ontario segment by Davidson and Morgan (1981), Davidson et al. (1982), and Davidson (1984) who used zones of continuous, flaggy gneissic layering or 'straight gneiss' to delineate an imbricate stack of mostly SEdipping domains and subdomains with distinctive lithologies, structural history and metamorphic grade (Fig. 1). Davidson et al. (1982) interpreted the stacked domains in the footwall and hanging wall of the Allochthon Boundary as Grenvillian thrust sheets or nappes, and Davidson (1984) specifically described the Muskoka and Parry Sound domains at the top of the stack as "crustal blocks or wedges [that have] overridden one another in a northwesterly direction" (p. 278). Culshaw et al. (1983, 1997) grouped the domains on both sides of the Allochthon Boundary into structural levels and their continuations at depth were subsequently verified on a LITHOPROBE deep seismic transect (White et al. 2000). The concept of structural levels was central to the comprehensive review of the structural and metamorphic evolution of the Ontario segment of the gneiss complex by Carr et al. (2000) and was also adopted in the Quebec segment where it was similarly supported by seismic data (e.g. Martignole and Calvert 1996; Nadeau and van Breemen 1998; Martignole et al. 2000).

In contrast to the view of the domains as exclusively a product of thrusting, Easton (1992) recognized that latest displacement on some domain boundaries, including those of the Muskoka domain, was extensional, and Culshaw et al. (1994) reported kinematic evidence for post-peak Ottawan extensional shear zones in the Britt domain and what is now known as the Shawanaga domain (Fig. 2). These interpretations were given concrete expression by $\mathrm{U}-\mathrm{Pb}$ zircon dating of extensional reworking of the Allochthon Boundary at $\sim 1020$ Ma by Ketchum et al. (1998), and since then a range of evidence for post-peak extension has been described (e.g. Nadeau and van Breemen 1998; Carr et al. 2000; Timmermann et al. 2002; Rivers 2008, 2012; Jamieson et al. 2010; Schwerdtner et al. 2014). However, as discussed below its extent remains poorly constrained.

Since the early 1980s the subdivision of the Ontario segment of the gneiss complex has been modified many times (e.g. Culshaw et al. 1983, 1994, 1997, 2004; Carr et al. 2000; Ketchum and Davidson 2000; Dickin and Guo 2001; Jamieson et al. 2007, 2010), and as noted some progress has been made in extending the framework into the Quebec segment (e.g. summary in Martignole et al. 2000). With respect to the latter point, the largely granulite-facies Algonquin domain in the hanging wall of the Allochthon Boundary in Ontario was cor- related with the Lac Dumoine domain in western Quebec by Rivers et al. (2012), but a structurally overlying unit corresponding to the Muskoka domain was not identified. Given this protracted history of changes in both the locations of domain boundaries and correlations among domains, as well as the interpretation of Rivers (2012) that the gneiss complex as a whole is a large domal metamorphic core complex, Schwerdtner et al. (submitted) proposed the new name, Ottawa River Gneiss Complex, after the river that bisects it. In describing the first-order components of the ORGC, they stated: "the segment of the ORGC in the hanging wall of the [Allochthon Boundary] is composed of the remnants of a deep-crustal thrust-sheet stack that was assembled in the Ottawan phase of the Grenvillian Orogeny $(\sim 1090-1020 \mathrm{Ma})$. In contrast, the [segment in its] footwall [...] is a thrust stack of parautochthonous rocks formed in the Rigolet phase at ca. 1000-980 Ma." Moreover, as shown by recent work and emphasized in this study, the ORGC is an archive of both preGrenvillian and Grenvillian tectonic history, of which the post-peak Ottawan part involved important extension during exhumation and cooling.

The correlation chart of Jamieson et al. $(2007,2010)$ for the Ontario segment of the ORGC (Fig. 2) is used as a tectonic template in this study. In this figure, the SE-dipping allochthonous sheets in the hanging wall of the Allochthon Boundary (structural levels 2-3) were emplaced during the main Ottawan collisional phase of the Grenvillian Orogeny ( 1090-1020 $\mathrm{Ma}$ ), and overlie the parautochthon in its footwall (structural level 1) that underwent its principal deformation in the Rigolet phase ( 1005-980 Ma; Rivers et al. 2012). Specifically the southeast part of structural level 3 is composed of the Muskoka domain and its Moon River and Seguin subdomains that are correlated with the Ahmic and Shawanaga subdomains farther northwest, all of which overlie the Algonquin-Lac Dumoine domain and related subdomains of structural level 2. The Wallace subdomain of the Muskoka domain was recently defined by Schwerdtner et al. (submitted).

\section{Grade and Timing of Metamorphism in the ORGC}

Structural levels 2-3 comprising most of the allochthonous part of the ORGC structurally above the Allochthon Boundary are composed almost entirely of high-grade metamorphic rocks with upper amphibolite-, granulite-, and rare relict eclogite-facies assemblages that formed during the Ottawan phase of the Grenvillian Orogeny (Carr et al. 2000; Rivers et al. 2012). Of relevance to this study is the observation of Davidson et al. (1982) that metamorphic assemblages in the Algonquin domain (structural level 2) at the base of the stack are principally granulite facies, whereas those in the overlying Muskoka domain (structural level 3) are principally amphibolite facies. Our work and that of others supports this general conclusion, but we show in this study that in detail the picture is more nuanced, with preservation of both prograde and retrograde assemblages in different parts of both domains.

In addition to a distinction based on metamorphic grade, several authors have followed Carr et al. (2000) in emphasizing that many of the gneisses in the Algonquin domain and equivalent subdomains in level 2 carry geochronological evidence for a high-grade metamorphism at $\sim 1.5-1.45 \mathrm{Ga}$ prior to Ottawan reworking during the Grenvillian Orogeny and are thus polymetamorphic (polycyclic), whereas those in the 


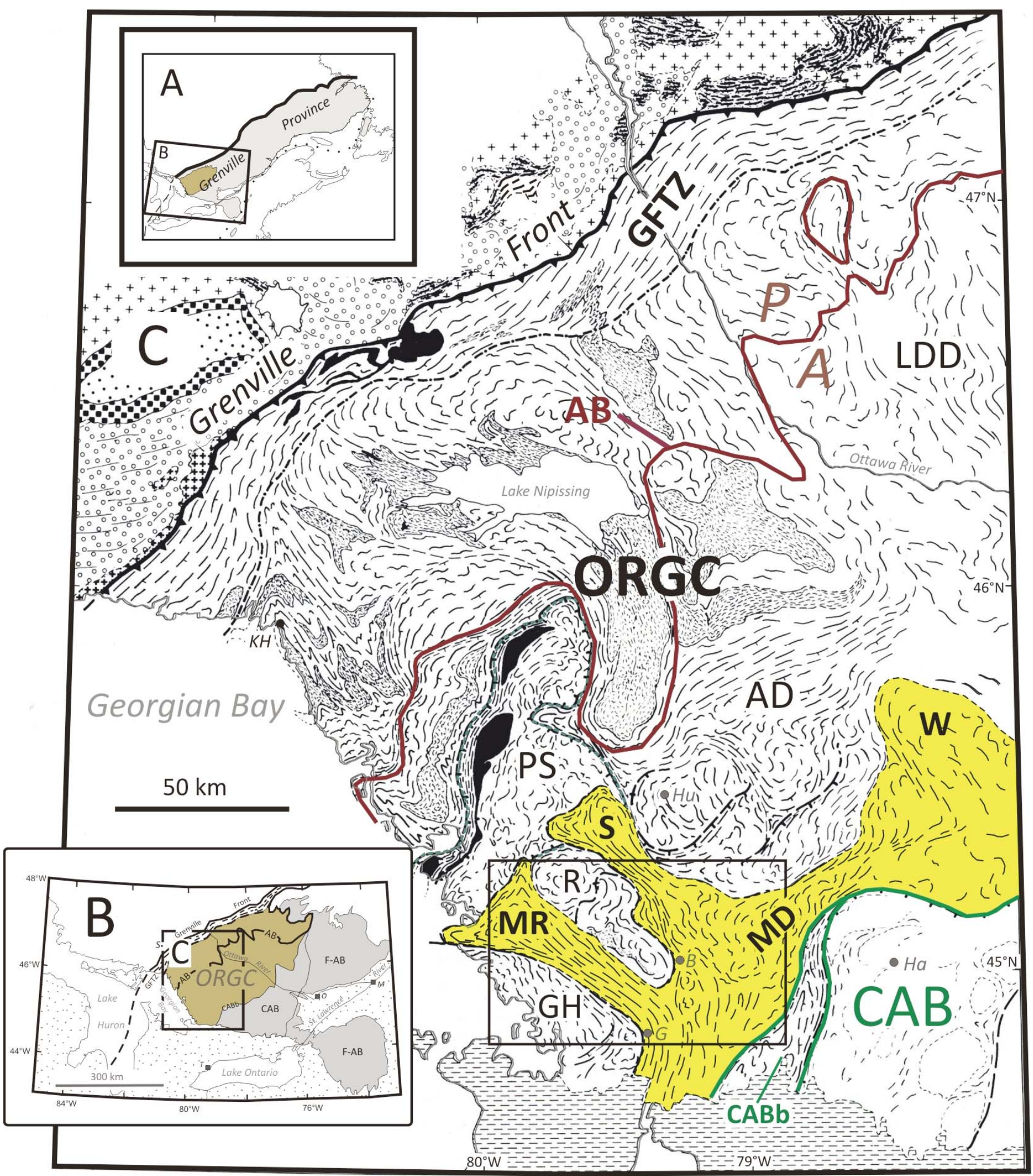

Figure 1. A-B: Location of the Ottawa River Gneiss Complex (ORGC, highlighted in brown) in the SW Grenville Province. The ORGC is bisected by the Ottawa River into Ontario and Quebec segments, and extends between the Grenville Front Tectonic Zone (GFTZ) and Composite Arc and Frontenac-Adirondack belts (CAB and F-AB). AB - Allochthon Boundary, $\mathrm{CABb}$ - Composite Arc Belt boundary zone; $M$ - Montréal, $O$ - Ottawa, $S$ - Sudbury, $T$ - Toronto. C: Foliation trend map of part of the Ontario segment of the ORGC, with the Muskoka domain (MD), including its NW-trending synformal Moon River (MR), Seguin (S) and Wallace (W) subdomains, highlighted. Short dashes - granitoid plutons, black - anorthosite bodies. AD - Algonquin domain, GH - Go Home subdomain, LDD - Lac Dumoine domain, PS - Parry Sound domain, R - Rosseau subdomain. The $\mathrm{AB}$ divides the ORGC into allochthonous $(A)$ and parautochthonous $(P)$ parts. Box shows approximate area of present study; $B$ - Bracebridge, $G$ - Gravenhurst, $\mathrm{Ha}$ - Haliburton, $\mathrm{Hu}$ - Huntsville, $\mathrm{KH}$ - Key Harbour. C modified from Davidson (1984); boundaries of Wallace subdomain are approximate; location of AB from Ketchum and Davidson (2000). 


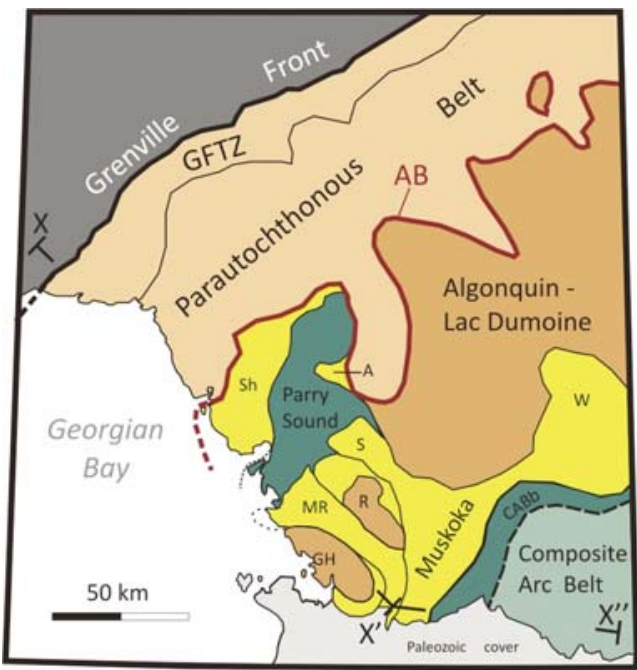

\section{Mesoproterozoic Laurentia}

\section{Orogenic foreland}

Parautochthonous polycyclic rocks, mostly $>1.5 \mathrm{Ga}$

Allochthonous polycyclic rocks, mostly $>1.5 \mathrm{Ga}$

Allochthonous monocyclic rocks, mostly $<1.5 \mathrm{Ga}$

\section{Accreted terranes}

Parry Sound domain and Composite Arc Belt Boundary zone ( $\mathrm{CABb}$ )

5 Composite Arc Belt
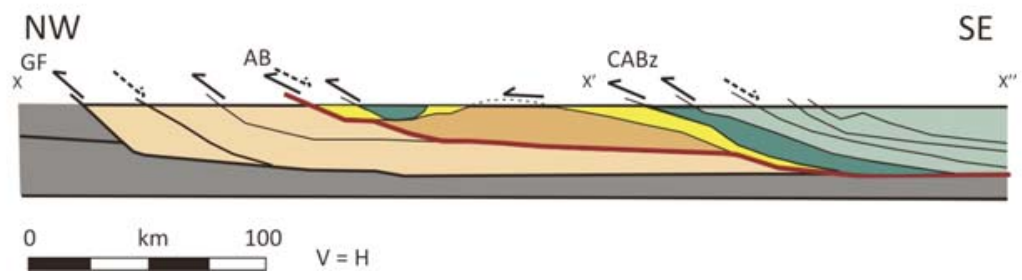

Figure 2. Tectonic map of the western Grenville Province and NW-SE crustal-scale cross-section X-X'-X" based on deep seismic data integrated with geological evidence showing division of the orogenic crust into 5 structural levels. The $<1.5 \mathrm{Ga}$ monocyclic rocks in the Muskoka domain and the structurally equivalent Shawanaga (Sh) and Ahmic (A) domains in structural level 3 overlie the mostly $>1.5$ Ga rocks in the Algonquin-Lac Dumoine domain (structural level 2) in the immediate hanging wall of the Allochthon Boundary (AB). GFTZ - Grenville Front Tectonic zone; GH, MR, R, S, W - Go Home, Moon River, Rosseau, Seguin and Wallace subdomains. Redrawn and slightly modified from Jamieson and Beaumont (2011), after Culshaw et al. (1997).

Muskoka domain and equivalent subdomains in level 3 were principally unmetamorphosed prior to the Grenvillian orogeny, and hence are monocyclic (Fig. 2).

\section{The Large Hot Orogen (LHO) Paradigm}

The term large hot orogen (LHO), introduced by Beaumont et al. (2001), was an outcome of the results of two-dimensional numerical thermal-mechanical scaled modelling of collisional orogenesis. The first applications were to the Himalaya-Tibet Orogen, but the concept quickly found application in the Grenville Province. In these models, prolonged convergence leads to the development of a wide plateau in the orogenic hinterland as crust is detached from the subducting sub-continental lithospheric mantle and shortened to double thickness. Due to the long duration of collision, and assuming reasonable values for mantle heat flow and internal heat generation in the crust, the numerical experiments predict that the mid and lower crust under the orogenic plateau will attain temperatures of $>700^{\circ} \mathrm{C}$ after about $20 \mathrm{~m}$.y. of collision. Partial melting of felsic lithologies under these conditions leads to the development of a $20-30 \mathrm{~km}$ wide crustal 'channel' of relatively low density, low-viscosity anatectic material (leucosome and ductile restite) that is transported under the plateau and may eventually be extruded at the orogenic front by one of two mechanisms depending upon its rheology: gravitational forcing of low-viscosity material due to the weight of the overlying plateau leading to 'homogeneous channel flow,' or tectonic forcing of higher-viscosity material due to the piston effect of newly introduced strong cool crust into the orogen leading to inho- mogeneous channel flow with formation of hot fold nappes' (Beaumont et al. 2006).

A numerical experiment based on these principles was compared to the crustalscale cross-section of the ORGC shown in Figure 2 (Jamieson et al. 2007; GO-3 series). In this experiment, tectonic forcing of the weak mid crust by the entry of progressively stronger crust into the orogen leads to heterogeneous channel flow and extrusion of ductile material from the channel analogous to a stack of hot crystalline nappes. In addition to the firstorder similarity of the crustal-scale architecture, a feature of this experiment that resonates with present understanding is the high-strain ductile deformation of the mid crust in a sub-horizontal regime (orogenic infrastructure) beneath an upper crust that remains little deformed away from the orogenic front (orogenic superstructure). Empirical evidence for Ottawan high strain and associated high-grade metamorphism in the orogenic infrastructure and their absence in the superstructure was described by Rivers (2012).

Jamieson and co-workers subsequently published a second set of numerical experiments potentially relevant to the Grenville Province in which convergence was stopped after prolonged collision and the orogen allowed to evolve as a result of gravitational body forces (GO-ST series; Jamieson et al. 2010; Jamieson and Beaumont 2011). From the perspective of the ORGC in the orogenic hinterland, the principal difference between the results of the two sets of experiments is that in the GO-ST series the crust undergoes a gravitationally-driven attenuation after convergence ceases and zones of high strain, potentially analogous to normal faults, develop as it proceeds. However, since strain discontinuities ('faults') are not permitted by the continuum-mechanics formulation and the resolution of the experiment is low, it is difficult to compare the model results with structures observed in nature.

\section{The Collapsed LHO Paradigm}

Implicit in the GO-ST series of experiments by Jamieson et al. (2010) is the understanding that LHOs eventually undergo gravitationally driven collapse once the mid crust becomes thermally or melt-weakened beyond a critical value and/or the tectonic forces holding up the orogen decay. In the case of the western Grenville Province, the assembly of empirical evidence pointing to important post-peak ductile extensional shearing and crustal thinning, within both the ORGC and in the tectonically overlying Composite Arc Belt (CAB), has been ongoing for more than two decades. It includes a combination of structural evidence (e.g. van der Pluijm and Carlson 1989; Culshaw et al. 1994; Busch and van der Pluijm 1996; Busch et al. 1997; Schwerdtner et al. 2005, 2010b; Selleck et al. 2005), metamorphic evidence (Busch et al. 1996b; Rivers 2008), and a wide range of geochronological evidence including $\mathrm{U}-\mathrm{Pb}$ 


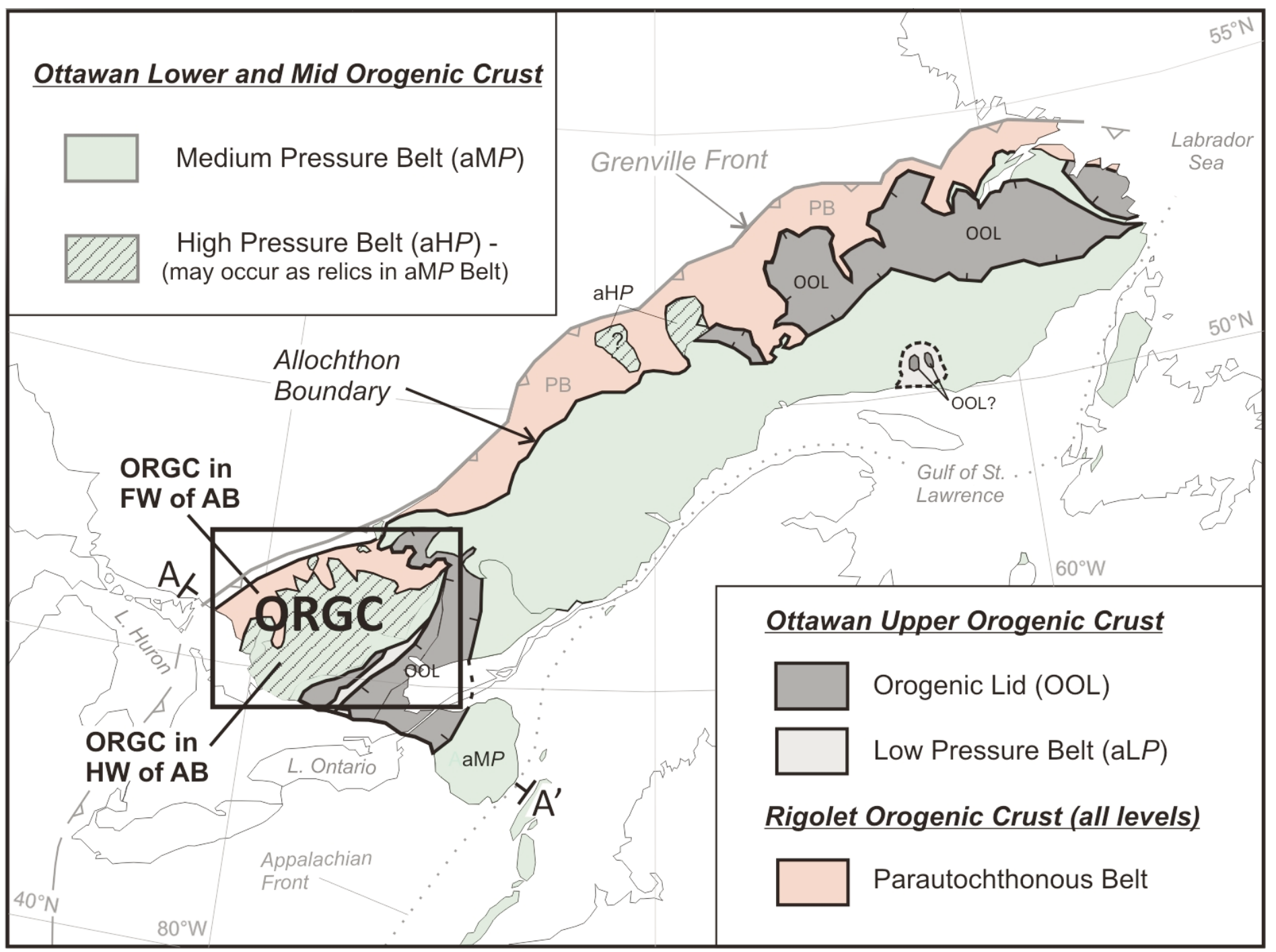

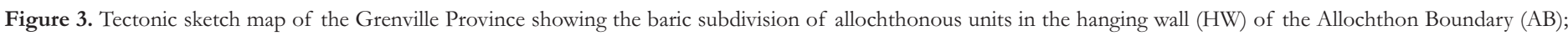

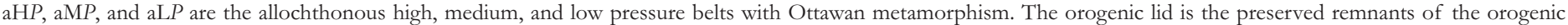

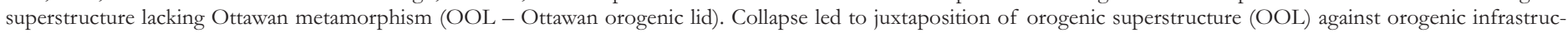
ture (ORGC) along normal-sense shear zones. FW - footwall. Box shows approximate location of study area in the ORGC. Slightly modified from Rivers (2012).

data on titanite (Mezger et al. 1991), zircon (Corrigan and van Breemen 1997; Ketchum et al. 1998), and monazite (Wong et al. 2012), and ${ }^{40} \mathrm{Ar} /{ }^{39} \mathrm{Ar}$ dating on hornblende (e.g. Cosca et al. 1991, 1992, 1995; Busch et al. 1996a; Streepey et al. 2004). Initially, the evidence for extension within the upper-crustal CAB and mid-crustal ORGC (orogenic superstructure and infrastructure, respectively) was evaluated separately (e.g. Mezger et al. 1991; Culshaw et al. 1994; Streepey et al. 2004; Selleck et al. 2005). However, more recently the data from both levels have been integrated with estimates of regional peak pressure variations during the Ottawan metamorphism, leading to a more holistic picture (Fig. 3; Rivers 2008; 2012; Rivers et al. 2012; McLelland et al. 2013; Schwerdtner et al. 2014). In this interpretation, parts of the orogenic superstructure, preserved segments of which are referred to as the orogenic lid, are juxtaposed against exhumed mid-crustal gneiss terranes such as the ORGC (orogenic infrastructure), implying that after crustal thickening and peak metamorphism the orogen underwent profound orogenic collapse (also known as gravitational collapse, extensional collapse, or gravitational spreading).
Rivers (2008, 2012) proposed a conceptual model to explain the crustal architecture of the western Grenville Province that integrated empirical evidence from structural and metamorphic measurements in the ORGC and CAB with results from two-dimensional numerical experiments of orogenic collapse (e.g. Rey et al. 2001, 2009; Vanderhaeghe 2009). In this model, the mechanisms of extensional flow in the crust undergoing collapse varied with depth, such that megaboudinage of the strong upper crust was accompanied by flow of the underlying gneissic mid crust into the neck regions between adjacent megaboudins, collectively leading to the formation of large $(\geq 100 \mathrm{~km}$ diameter) domical metamorphic core complexes (Fig. 4). In this setting, it is inferred that most major tectonic boundaries either formed or were reworked in extension, which was predominantly SE-directed in the ORGC, but both NW- and SE-directed elsewhere (Fig. 4).

\section{Study Area and Definition of Map Units}

The focus of this study is the allochthonous segment of the ORGC, to the southeast of and structurally above the 


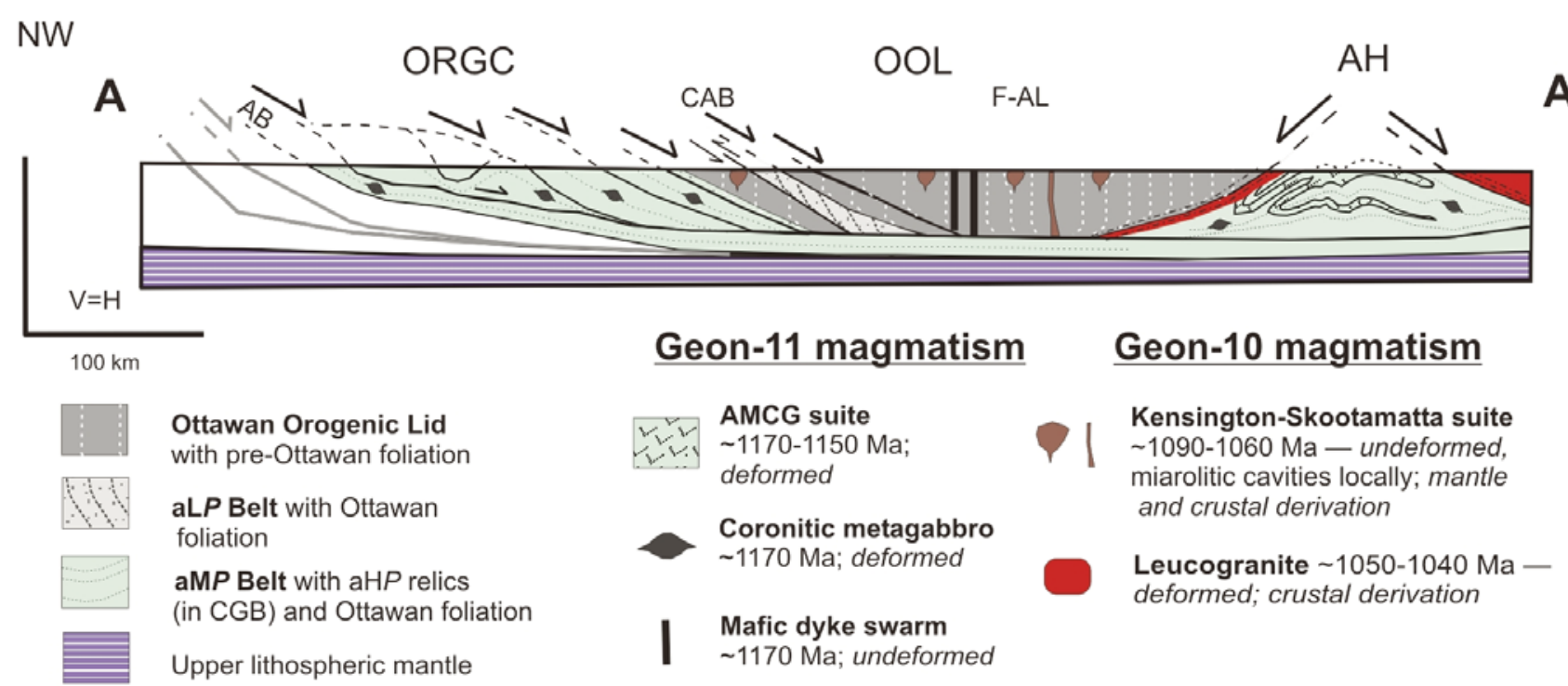

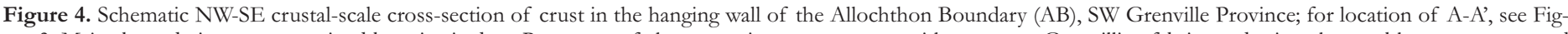

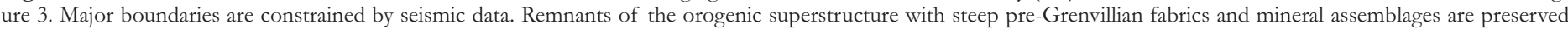

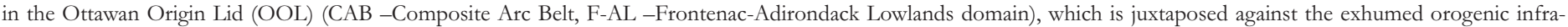

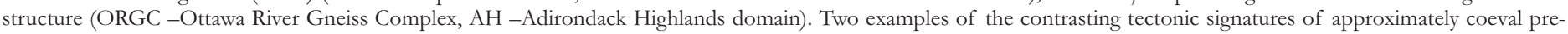

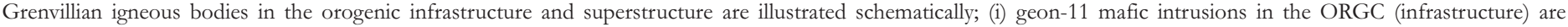

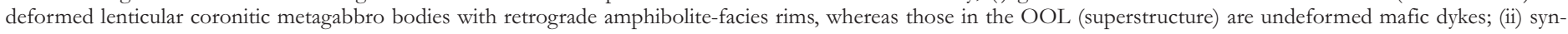

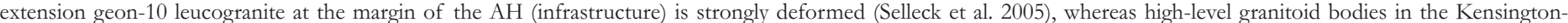

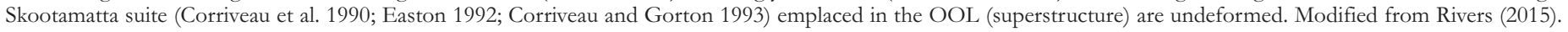

Allochthon Boundary. Our specific interest is the Muskoka domain in structural level 3, a SE-dipping sheet-like body with several NW-trending synformal lobes, and its contact relationships with the structurally underlying Algonquin domain and overlying Composite Arc Belt. Although most of the data, examples and illustrations come from the area of the box in Figure 1, our observations and measurements are considerably more wide-ranging, extending beyond the eastern limit of the figure.

Geological maps of the study area show that it is principally underlain by two orthogneiss suites: (i) $\geq 1.46 \mathrm{Ga}$ calcalkaline 'grey gneiss suite' (informal name) composed of metatonalite, -granodiorite and -gabbro, and (ii) 1.46-1.43 Ga Atype meta-monzonite, -monzodiorite, -gabbro and -anorthosite and related members of an 'AMCG suite' (Lumbers and Vertolli 2000a, b; Lumbers et al. 2000). Geochemical and isotopic data indicate that both suites are juvenile, and they have been interpreted to represent remnants of a Mesoproterozoic continental-margin arc and backarc basin respectively (Dickin and McNutt 1990; Timmermann et al. 1997, 2002; Nadeau and van Breemen 1998; McMullen 1999; Carr et al. 2000; Rivers and Corrigan 2000; Slagstad et al. 2004a, b, 2009; Dickin et al. 2008, 2014). A third unit, (iii), not shown on regional geologic maps, consists of massive to weakly deformed granite pegmatite dykes up to a few metres wide that cross-cut the older gneisses.

All three units occur in both the Muskoka domain (structural level 3) and the underlying Algonquin domain (structural level 2). As elaborated below, distinction between the gneissic units in the two structural levels is principally a function of their metamorphic grade and strain intensity. Hence, although the Algonquin and Muskoka domains are clearly distinguished on tectonic maps such as those shown in Figures 1 and 2, they are less evident on the 1:50,000 lithological maps.

High-grade metamorphism in the two orthogneiss suites took place during the Ottawan phase of the Grenvillian orogeny from 1090-1020 Ma (e.g. Timmermann et al. 1997, 2002; McMullen 1999; Slagstad et al. 2004a, 2009). Most observed contacts between gneissic units are tectonic, but relict intrusive contacts are preserved locally. On the other hand, the rectiplanar margins of the cross-cutting granite pegmatite dykes indicate that they intruded into the gneissic rocks after ductile deformation had ceased and they were exhumed and cooled, and available data suggest they crystallized at $\sim 1000 \mathrm{Ma}$ (i.e. post-Ottawan; Corrigan et al. 1994; Bussy et al. 1995).

\section{PETROLOGIC OBSERVATIONS}

\section{Ottawan Metamorphism in the Algonquin Domain}

As noted in the introduction, the initial subdivision of the southeast ORGC was in part based on metamorphic grade, with the Algonquin domain (structural level 2) being predominantly underlain by granulite-facies rocks and the Muskoka domain (structural level 3) by upper amphibolite-facies rocks (e.g. Davidson and Morgan 1981; Davidson et al. 1982; Culshaw et al. 1983). Small pods and lenses of relict eclogite-facies rocks were discovered at discrete structural levels in both domains by Davidson (1990). Subsequent work has shown that some granulite-facies assemblages in the Algonquin domain exhibit evidence of variable replacement by amphibolite-facies assemblages and the eclogite-facies assemblages are almost completely replaced by granulite- and amphibolite-facies 
assemblages. Geochronological data (e.g. Ketchum and Krogh 1997, 1998; Ketchum et al. 1998), although not unequivocal, have been interpreted to indicate that the eclogite-facies metamorphism in the Algonquin domain took place at $\geq 1090 \mathrm{Ma}$, the widespread granulite-facies overprint occurred at $\sim 1080$ $\mathrm{Ma}$, and was followed by variable retrogression to amphibolitefacies assemblages (see Rivers et al. 2012, p. 180 for discussion). Peak $P-T$ determinations for the granulite-facies rocks of the Algonquin domain are $850-1100 \mathrm{MPa}$ and $750-850^{\circ} \mathrm{C}$ (Anovitz and Essene 1990), the wide range probably being due to post-peak re-equilibration.

\section{Ottawan Metamorphism in the Muskoka Domain}

\section{Assemblages, $\mathbf{P}-\mathbf{T}$ Conditions and Timing}

Although metamorphic mineral assemblages in the Muskoka domain and structural level 3 are principally upper amphibolite facies, patches and relics of granulite-facies assemblages are widespread (e.g. Pattison 1991; Timmermann et al. 1997, 2002) and relict eclogite has been reported from the Shawanaga subdomain (Jamieson et al. 2003). In the study area, the grey gneiss suite is extensively migmatitic in most outcrops due to the presence of leucosome, whereas the units of the AMCG suite are generally more homogeneous in appearance. Granulite-facies assemblages in both units are principally composed of Hbl $\pm C p x \pm O p x \pm B t-Q t z-P l \pm O r-L i q$ (mineral abbreviations after Whitney and Evans 2010), with Hbl $\pm B t$ commonly mantling pyroxene and contributing to the definition of the gneissic fabric and straight gneiss layering. Assemblages in amphibolite-facies gneiss are similar, but lack $O p x \pm C p x$. Most leucosomes are strongly attenuated leading to a stromatic texture that contributes to the gneissic layering, but some are cross-cutting (see also Timmermann et al. 1997, 2002; Slagstad et al. 2005).

Estimated peak $P-T$ conditions for the granulite-facies assemblages in the Muskoka domain are $800-1150 \mathrm{MPa}$ and 750-850 ${ }^{\circ} \mathrm{C}$ (Anovitz and Essene 1990; Pattison 1991; Culshaw et al. 1997; Carr et al. 2000; Timmermann et al. 2002), i.e. comparable to those in the underlying Algonquin domain. $\mathrm{U}-\mathrm{Pb}$ zircon estimates for the time of peak granulite-facies metamorphism in the Muskoka domain are $\sim 1080 \mathrm{Ma}$ (lower intercepts of TIMS and SHRIMP analyses; Bussy et al. 1995; Timmermann et al. 1997; Slagstad et al. 2004a, b), again comparable to those in the Algonquin domain within uncertainties. Moreover, peak $P-T$ estimates for the amphibolite-facies assemblages in the Muskoka domain are not distinctly different from those for the granulites, being in the range $1000-1100 \mathrm{MPa}$ and $750-800^{\circ} \mathrm{C}$, leading Timmermann et al. (2002) to deduce that the distribution of granulite- and amphibolite-facies assemblages in the transition zone was a function of the $a_{\mathrm{H} 2 \mathrm{O}}$ in the ambient fluid. Timmermann et al. (1997) dated a Hbl-Bt-bearing, foliation-parallel leucosome in amphibolite-facies gneiss in the Muskoka domain at $1064 \pm 18 \mathrm{Ma}$ (U-Pb zircon, TIMS), a result subsequently confirmed more precisely by the SHRIMP method (1067 $\pm 9 \mathrm{Ma}$; Slagstad et al. 2004b), and Bussy et al. (1995) presented U-Pb TIMS data for metamorphic zircon in dykes in the Moon River subdomain that bracketed the timing of amphibolite-facies ductile deformation between ca. 1065 and $1045 \mathrm{Ma}$.

\section{Granulite Formation and the Role of Fluids}

Several petrological studies of prograde granulite formation in the Muskoka domain have highlighted the important role played by infiltration of low $a_{\mathrm{H} 2 \mathrm{O}}$ fluid. In (i) amphibolite-facies metagabbro bodies with anastomosing diffuse $O p x$-bearing tonalitic veins in the Seguin subdomain and Muskoka domain sensu stricto, Pattison (1991) and Timmermann et al. (2002) respectively concluded that formation of metamorphic $O p x$ in the tonalitic veins occurred by subsolidus dehydration of $\mathrm{Hbl}$ driven by infiltration of a low $a_{\mathrm{H} 2 \mathrm{O}}$ fluid. Later coarser-grained veins with sharp margins in the example studied by Pattison (1991) were deduced to be a result of closed-system anatexis. Timmermann et al. (2002) also described two other types of granulite and granulite-formation process in felsic to intermediate gneiss in the Muskoka domain; (ii) patchy granulite, consisting of metre-scale diffuse patches overprinting the amphibolite-facies fabric that formed by Bt-dehydration melting; and (iii) rare, late $O p x$-bearing felsic veins that truncate the amphibolite-facies fabric and developed by infiltration of a low $a_{\mathrm{H} 2 \mathrm{O}}$ melt \pm fluid. In all three occurrences, $O p x$ may display thin retrograde $\mathrm{Hbl}$ rims that were inferred to be a result of back-reaction between $\mathrm{Opx}$ and $\mathrm{H}_{2} \mathrm{O}$ formed during melt crystallization (Timmermann et al. 2002).

In contrast to these examples of well preserved granulite, we have observed many occurrences of highly retrogressed granulite relicts in amphibolite-facies gneiss throughout the Muskoka domain, prompting us to add a fourth category, (iv) relict $O p x \pm C p x$-bearing granulite-facies assemblages in leucosomes, porphyroclasts and boudins in which the pyroxene is rimmed to completely replaced by $\mathrm{Hbl} \pm B t$ aggregates that are elongate in the high-strain amphibolite-facies fabric. This latter relationship is similar to the 'textbook' evidence for variably pervasive textural and mineralogical retrogression of granulitefacies rocks in an Archean terrane in West Greenland described by McGregor and Friend (1997). Examples of retrogressed granulite in the Muskoka domain are shown in Figure 5.

Recalling that amphibolite-facies assemblages typify the Muskoka domain as originally defined (Davidson et al. 1982), we interpret these observations collectively to indicate that although prograde granulite-facies assemblages and textures are locally well preserved (i-iii above), on the scale of the domain as a whole they are relict and apart from patchy remnants and preserved 'islands' they are variably overprinted by post-peak retrograde amphibolite-facies assemblages (iv above), in places to such an extent that their original granulitefacies history is essentially obliterated. In the field, evidence for progressive replacement of granulite-facies assemblages by amphibolite-facies assemblages may be indicated by the colour of the feldspar (plagioclase and/or orthoclase). In outcrops in which the feldspar has a greenish hue and greasy lustre, the mafic phases are usually aggregates of $C p x \pm O p x$ (or have cores of these minerals surrounded by $H b l \pm B t$ ) indicative of recrystallization under granulite-facies conditions, whereas in outcrops in which the feldspars are whitish to pinkish, the mafic minerals are typically aggregates of $H b l \pm B t$ implying thorough recrystallization under amphibolite-facies conditions. On the basis of our observations, the retrograde recrystallization may have taken place under either static (weakly strained 

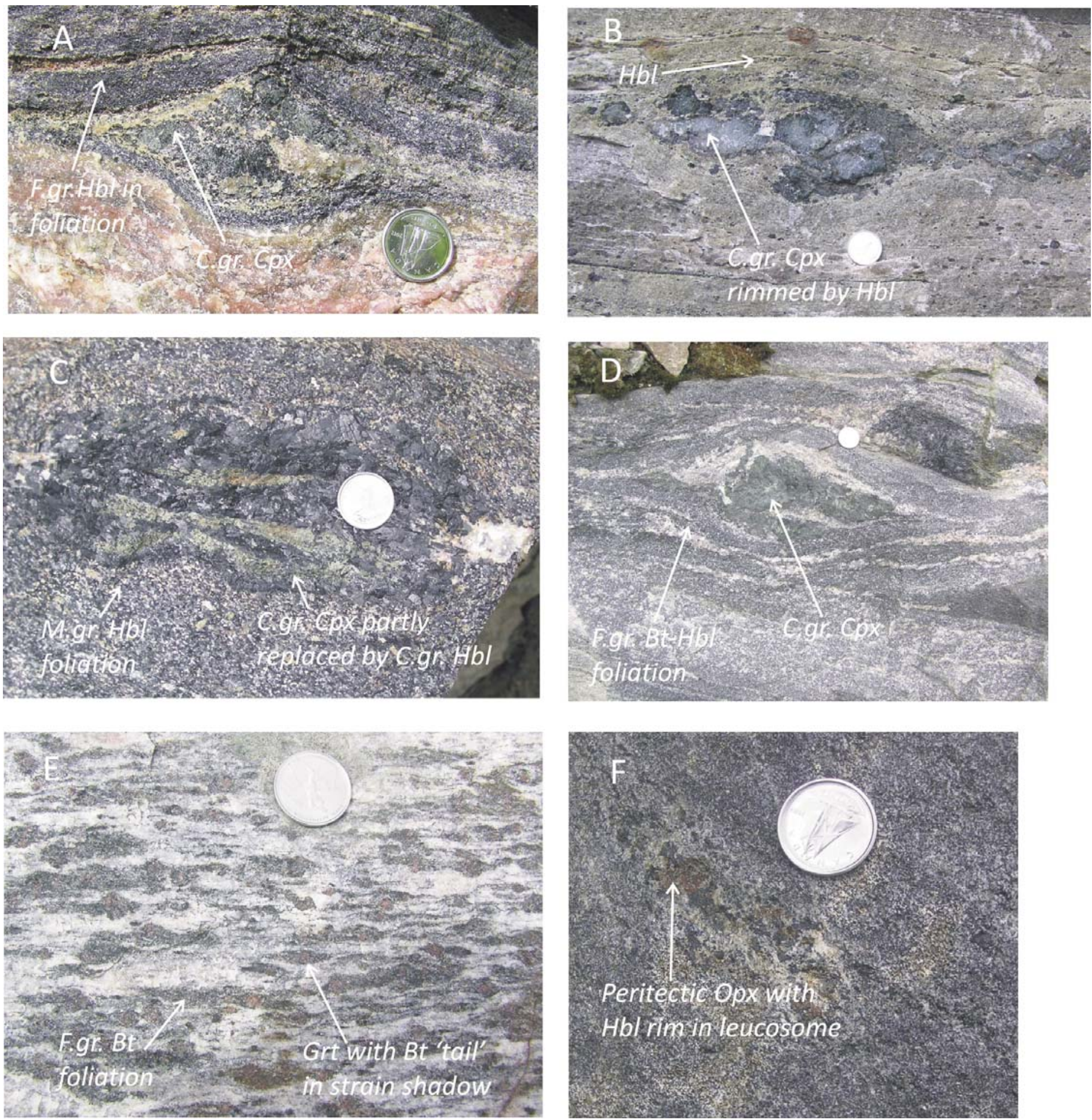

Figure 5. Photographs showing details of the high strain amphibolite-facies fabric in the Muskoka domain, its retrograde character indicated by the presence of relict anhydrous phases, remnants of the former granulite-facies assemblage, that are partially replaced by hydrous phases. A-D: Inclusions in grey gneiss in which $C p x$ is variably replaced by $\mathrm{Hbl}$ in high-strain fabric composed of $\mathrm{Hbl \pm B}$, note thinning of tectonic layering above inclusion in A and B and incipient boudinage of inclusion in B and C. E: Grt partially replaced by elongate $B t$ aggregates in monzodioritic gneiss. F: Spidery Opx-bearing tonalitic leucosome in mafic gneiss in which $O p x$ is partially replaced by $H b l$. C.gr., M.gr., and F.gr. - coarse-, medium- and fine-grained.

or undeformed; rare) or dynamic (high-strain; common) conditions. We interpret this to imply that incursion of hydrous fluid into the Muskoka domain occurred after the peak of granulite-facies metamorphism when the crust was still hot and deeply buried, and was commonly accompanied by high strain. The implications of this deduction and of the spatial distribution of the relict granulite-facies rocks are discussed in a later section.

\section{Anatexis, Migmatite Formation and the Role of Fluids}

As discussed in the previous section, Timmermann et al. (2002) proposed that Bt-dehydration melting led to formation 
of $O p x$-bearing leucosome in patchy granulite in the Muskoka domain. Specifically they proposed two leucosome-forming reactions with peritectic $\mathrm{Hbl}$ and $\mathrm{Opx}$ as follows:

$$
\begin{aligned}
& B t+P l+Q t z=H b l+K f s+L i q \\
& B t+P l+Q t z=O p x+K f s+L i q
\end{aligned}
$$

Hornblende-bearing leucosomes (1) are widespread in the Muskoka domain, whereas Opx-bearing leucosomes (2) are mostly restricted to areas of patch granulite. Prograde reactions (1) and (2) occur when the upper temperature stability of $B t$ in the presence of the other reactants is exceeded. No evidence for Hbl-dehydration melting was observed by Timmermann et al. (2002), compatible with their $T$ estimates of $750-800^{\circ} \mathrm{C}$. Slagstad et al. (2005) pointed out that due to the low modal abundance of $B t$ in typical granodioritic orthogneiss the amount of melt generated by (1) and (2) would have been limited $(\leq 10 \%)$.

Slagstad et al. (2005) recognized two migmatite morphologies in dioritic and granodioritic gneiss they termed patch and stromatic migmatite. Melanosomes are present in both cases, supporting geochemical evidence for in situ derivation of leucosome in the host gneiss. The patch migmatite in dioritic gneiss is tonalitic in composition, carries prominent peritectic $\mathrm{Hbl}$ as poikiloblastic or skeletal grains, and is an irregularly distributed feature, in part fracture-related, that composes $\leq 5 \%$ of the rock by volume. The authors concluded that it developed from a sub-solidus, water-fluxed melt reaction such as:

$$
\mathrm{Bt}+\mathrm{Pl}+\mathrm{Qtz}+\mathrm{H}_{2} \mathrm{O}=\mathrm{Hbl}+\mathrm{Liq}
$$

Although similar to (1) in terms of solid reactants, Slagstad et al. (2005) referred to experimental results indicating that formation of peritectic $\mathrm{Hbl}$ only occurs in melts with 3-4 wt.\% $\mathrm{H}_{2} \mathrm{O}$, levels not attained by $B$-dehydration melting (see also Brown 2013).

Stromatic migmatite studied by Slagstad et al. (2005) is common in granodioritic gneiss and consists of concordant to subconcordant $\mathrm{Hbl}$-bearing leucosome comprising 20-30\%, up to locally $40-50 \%$ of the rock by volume. Some leucosomes are undeformed and injected along the foliation or into boudin necks and shear bands, whereas others are folded, with the presence of several generations being interpreted to indicate the volume of leucosome represents the vestiges of a cumulative record rather than the amount present at any one time. Slagstad et al. (2005, p. 899) concluded: "The very high leucosome proportions in stromatic migmatites [...] are inconsistent with in situ partial melting, both because granodioritic gneisses are unlikely to yield such high melt proportions and because complementary residual rocks are missing. Although the concordant melanosomes may represent residues after partial melting, the small volume of melanosomes (typically only 1-2 mm thick) cannot account for the volume of the leucosome in the rocks." As a result, they concluded that (p. 915): "The field, petrographic, and geochemical evidence from the stromatic migmatites suggests that in addition to in situ partial melting, a significant proportion of the leucosome present [...] was derived from external sources." More recently, Aranovich et al. (2013) have shown how dissolved K-Na-bearing brines in fluid-present melting drive the minimum melt towards more Qtr- and $K f$-rich compositions (so-called brine trend), which may explain the high $\mathrm{K}_{2} \mathrm{O}$ contents in some leucosomes studied by Slagstad et al. (2005).

Collectively these studies of migmatite formation in the Muskoka domain suggest (i) in granodioritic gneiss, small quantities of leucosome $(\leq 10 \%)$ were formed by Bt-dehydra- tion melting during prograde metamorphism, some of which may have been lost, but (ii) a significant proportion of the 20-50\% leucosome in granodioritic gneiss was derived externally. In dioritic gneiss, (iii) limited melt formation $(\leq 5 \%)$ in patches and along fractures was driven by water- $( \pm \mathrm{K}-\mathrm{Na}$ brine-) fluxed melting under subsolidus conditions; and in metagabbro (iv) the formation of a network of tonalitic leucosomes with peritectic Opx was driven by influx of a low $a_{H 2 O}$ fluid that promoted $B t$ breakdown.

Biotite-dehydration melting implies the absence of a hydrous fluid phase (or the presence of a fluid with a low $a_{H 2 O}$ ), but water-fluxed melting requires the presence of a hydrous fluid phase (or a fluid phase with a high $a_{H 2 O}$ ), so they cannot occur at the same place and time. Moreover the drivers, melting conditions and physical effects of the two processes are different: dehydration melting is driven by $T$ exceeding the solidus and results in an increase in the volume of the system $\left(\Delta \mathrm{V}_{\text {melting }}\right.$ positive) potentially leading to brittle failure and melt expulsion, whereas water-fluxed melting in a suprasolidus terrane is driven by fluid influx and leads to a reduction in volume $\left(\Delta \mathrm{V}_{\text {melting }}\right.$ negative) (Clemens and Droop 1998; Weinberg and Hasalová 2015). This suggests that if both processes took place in the same area, as indicated by the cited studies, they must have occurred sequentially, likely with dehydration melting during prograde metamorphism preceding fluid-fluxed melting at or after the metamorphic peak. Injection of melt from outside the system could have occurred at either time. Another relevant issue is that leucosomes produced by dehydration melting are $\mathrm{H}_{2} \mathrm{O}$-undersaturated and able to rise in the crust before reaching their solidi, whereas water-fluxed magmas are $\mathrm{H}_{2} \mathrm{O}$-saturated and unable to rise significantly before freezing. This difference has implications for the preservation of leucosome at its site of formation.

\section{Metamorphism of Al-rich Mafic Rocks}

Metamorphic mineral assemblages and structures in small lenses and layers of Al-rich metagabbro and mafic gneiss in the grey gneiss unit warrant special discussion because they form the basis for arguments regarding the timing and strain associated with decompression and exhumation of the gneiss complex. Prograde metamorphism of these lithologies is inferred to have led to the peak assemblage $G r t \pm C p x \pm O p x \pm H b l \pm P l \pm F e T i$ oxide $\pm B t \pm C a l$ and to a microstructure in which grossular-rich garnet formed porphyroblasts at the expense of calcic plagioclase (Schwerdtner et al. 1974). Consistent with this interpretation, these authors reported examples from the Moon River subdomain in which small grains of sillimanite and quartz occurred as inclusions in garnet or in plagioclase surrounding resorbed garnet, but are absent from the matrix. However, an aluminosilicate phase may not form in bulk compositions that are undersaturated in alumina, the $\mathrm{Al}$ instead entering solid-solution phases such as pyroxene or amphibole via the Tschermak exchange. In this case, possible reactions are:

$$
\begin{aligned}
& T r-H b l+A n=T s-H b l+G r t+Q t z \\
& T r-H b l+A n=T s-C p x \pm T s-O p x+G r t+Q t z+H_{2} O
\end{aligned}
$$

Both reactions are sensitive to pressure, the left-hand sides as written being the low-P sides (e.g. Berman 1991; Schaubs et al. 2002). Our observations suggest that some $P l$ remained as a stable phase in the peak $P-T$ assemblage, implying the rocks were granulite rather than eclogite. 

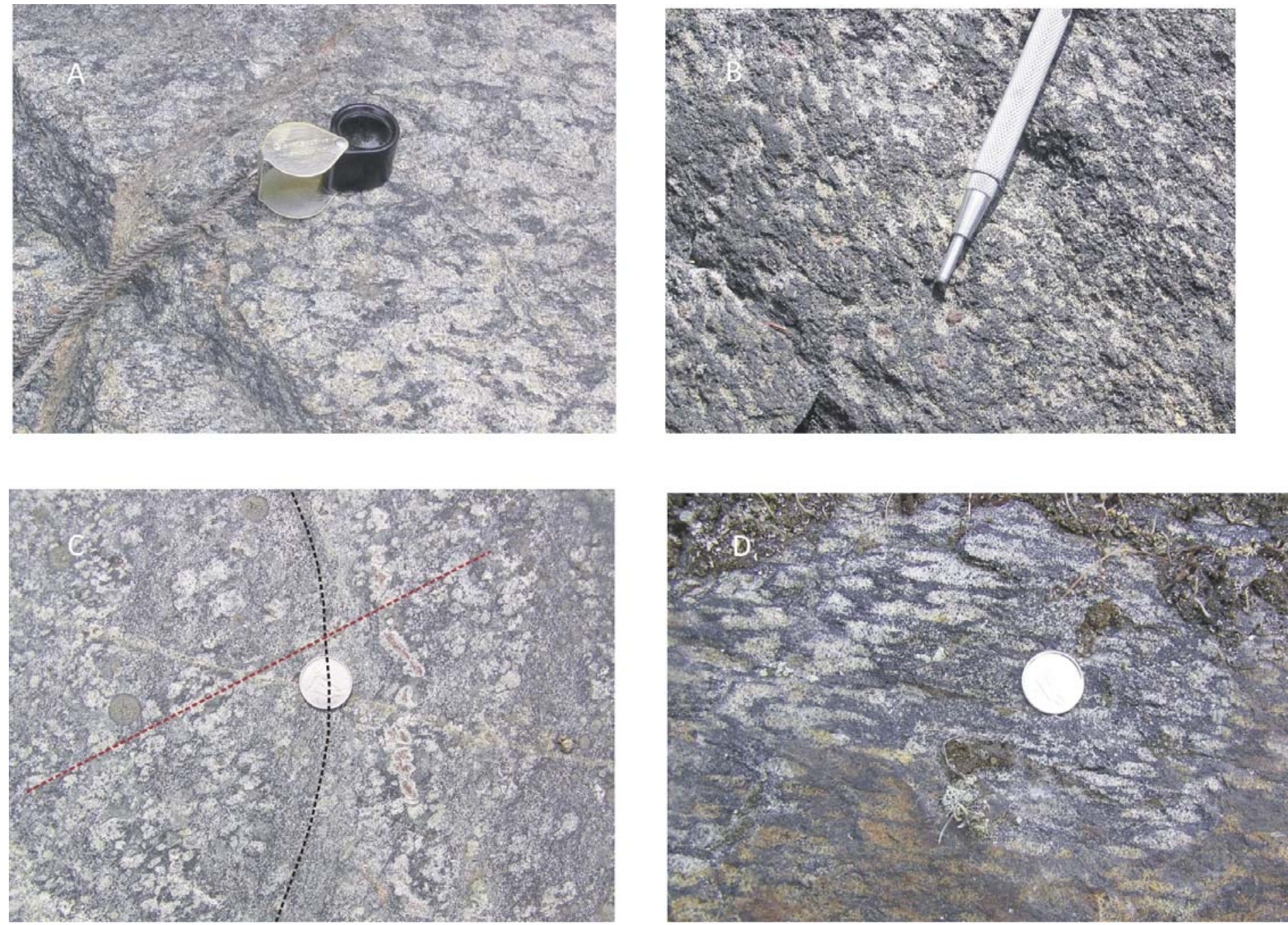

Figure 6. An-rich plagioclase aggregates pseudomorphing former Grt porphyroblasts in metagabbro and mafic gneiss, Muskoka domain (A). Relict Grt is present in cores of some pseudomorphs in B and C. In B, relict subophitic texture suggests the protolith was gabbro, whereas in C the presence of layering (dashed black line) overprinted by a weak tectonic fabric (dashed red line) suggests the protolith was mafic gneiss. D: Horizontal outcrop surface in the core of the Moon River synform about $20 \mathrm{~km} \mathrm{NW}$ of Gravenhurst. The elliptical shapes of plagioclase pseudomorphs provide evidence for ductile strain during or after decompression. In 3-dimensions, the pseudomorphs in (D) are prolate, their long axes trending NW-SE parallel to the hinge line of the Moon River synform, implying a component of post-peak constrictional strain parallel to the axis of the cross-fold.

We deduce that during decompression and retrogression at high temperature, reactions (4) and (5) operated in reverse, resulting in the formation of $A n$-rich plagioclase at the expense of Grs-rich garnet. This led to the formation of a distinctive replacement texture in which $\mathrm{Pl}$ aggregates pseudomorph former Grt porphyroblasts (Fig. 6), with relict Grt and Sil remaining in the cores of some pseudomorphs facilitating interpretation (Schwerdtner et al. 1974). Evidently decompression was accompanied by hydrous retrogression in many cases, because pyroxenes surrounding the $\mathrm{Pl}$ pseudomorphs after Grt are partly to completely replaced by $H b l \pm B t$.

\section{Strain During Decompression}

Pseudomorphs mimic the shapes of the objects they replace, so in the absence of strain it is assumed that the shapes of idioblastic Grt would be inherited by the $\mathrm{Pl}$ aggregates. Hence, distorted shapes of the aggregates may be used as qualitative indicators of the shape and magnitude of strain acquired after the metamorphic peak during decompression and retrogression (Waddington 1973; Schwerdtner et al. 1974, 1998, 2005,
2014). However, because idioblastic garnet grains are nonspherical the imprecision of strain estimates increases with increasing strain level (Schwerdtner et al. 1974, their fig. 5).

In the Muskoka domain, some pseudomorphic $\mathrm{Pl}$ aggregates after Grt are quasi-idioblastic (Fig. 6A-B), indicating that decompression of the metagabbro/mafic gneiss was not accompanied by significant finite strain at the dm-scale at those localities, whereas others are moderately to highly distorted in two- or three-dimensions and resemble prolate or oblate ellipsoids, thereby providing information on the local geometry of ductile deformation during and/or after decompression \pm retrogression (Fig. 6C-D).

Extrapolating from this interpretation suggests that part of the high strain embedded in the gneissic fabric of the ORGC occurred during decompression and retrogression. Indeed, the implication is that where the gneissic fabric is composed of post-peak amphibolite-facies assemblages, as we infer to be the case throughout much of the Muskoka domain, a significant component of the strain may have occurred after the peak of metamorphism during decompression and retrogression. 
Although this inference presently remains unquantified, it has profound implications for the interpretation of structures in the Muskoka domain of the ORGC as discussed further below.

\section{POST-PEAK EXTENSIONAL STRUCTURES FORMED DURING DECOMPRESSION AND RETROGRESSION}
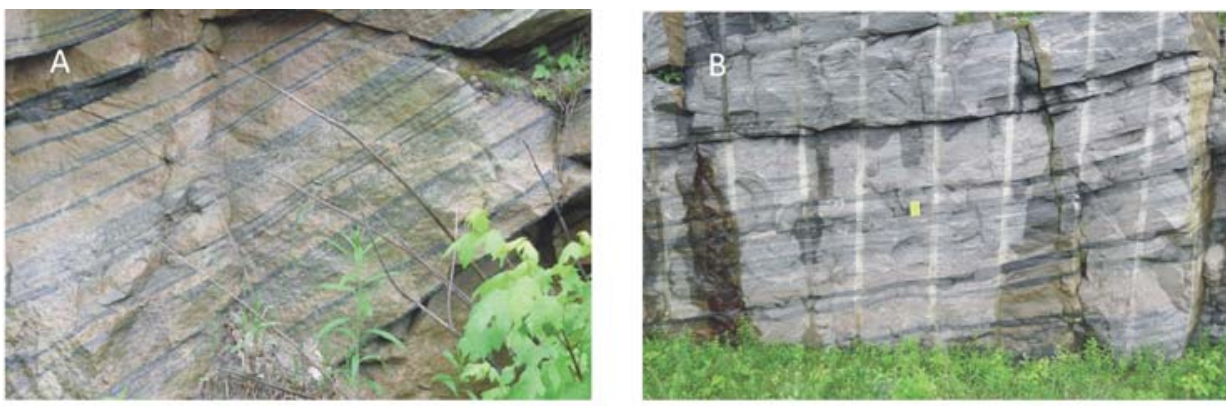

\section{Straight Gneiss Fabric}

Representative images of the straight gneiss fabric that characterizes much of the Muskoka domain are shown in Figure 7. On centimetre to metre scales, the alternation of straight pink to grey granitoid and black amphibolite layers is typical (Fig. 7A-D). Features indicative of its highstrain origin include mylonitic layers, stretched $\mathrm{Hbl}$ aggregates and rotated $\mathrm{Hbl}$ porphyroclasts (Fig. 7F-H, respectively). Hornblende and biotite are the principal mafic phases, and where pyroxenes are present they are relict and rimmed or surrounded by the high-strain $H b l \pm B t \pm P l \pm$ $K f \pm Q t z$ fabric (e.g. Figs. 5, 7E). From the shapes of deformed feldspar and hornblende aggregates we assess the strain in the straight gneiss to be $\mathrm{S}>\mathrm{L}$ to $\mathrm{S}>>\mathrm{L}$; although the extension direction (L) can generally be found in most outcrops, it is not prominent or present on all foliation surfaces.

In his description of straight gneiss in the ORGC in general, Davidson (1984) noted that "Amphibolite facies assemblages [in straight gneiss] occur in most [...] boundary zones [between domains]" (p. 276), which is consistent with our observations, even in cases where granulite-facies assemblages are stable within the domain itself. Thus, following the logic developed in the previous paragraphs, we deduce that the amphibolite-facies mineral assemblages defining the dominant fabric elements in the Muskoka domain, including the regional high-strain foliation that is widely expressed as a straight-gneiss fabric (Fig. 7), formed after peak metamorphism during decompression and retrogression. Moreover, we note that straight gneiss is not restricted to the margins of the Muskoka domain, but is also widespread within the interior implying the domain as a whole has undergone unusually high strain.

However, although the straight gneiss fabric in the Muskoka domain obviously has a high-strain history, it is not defined
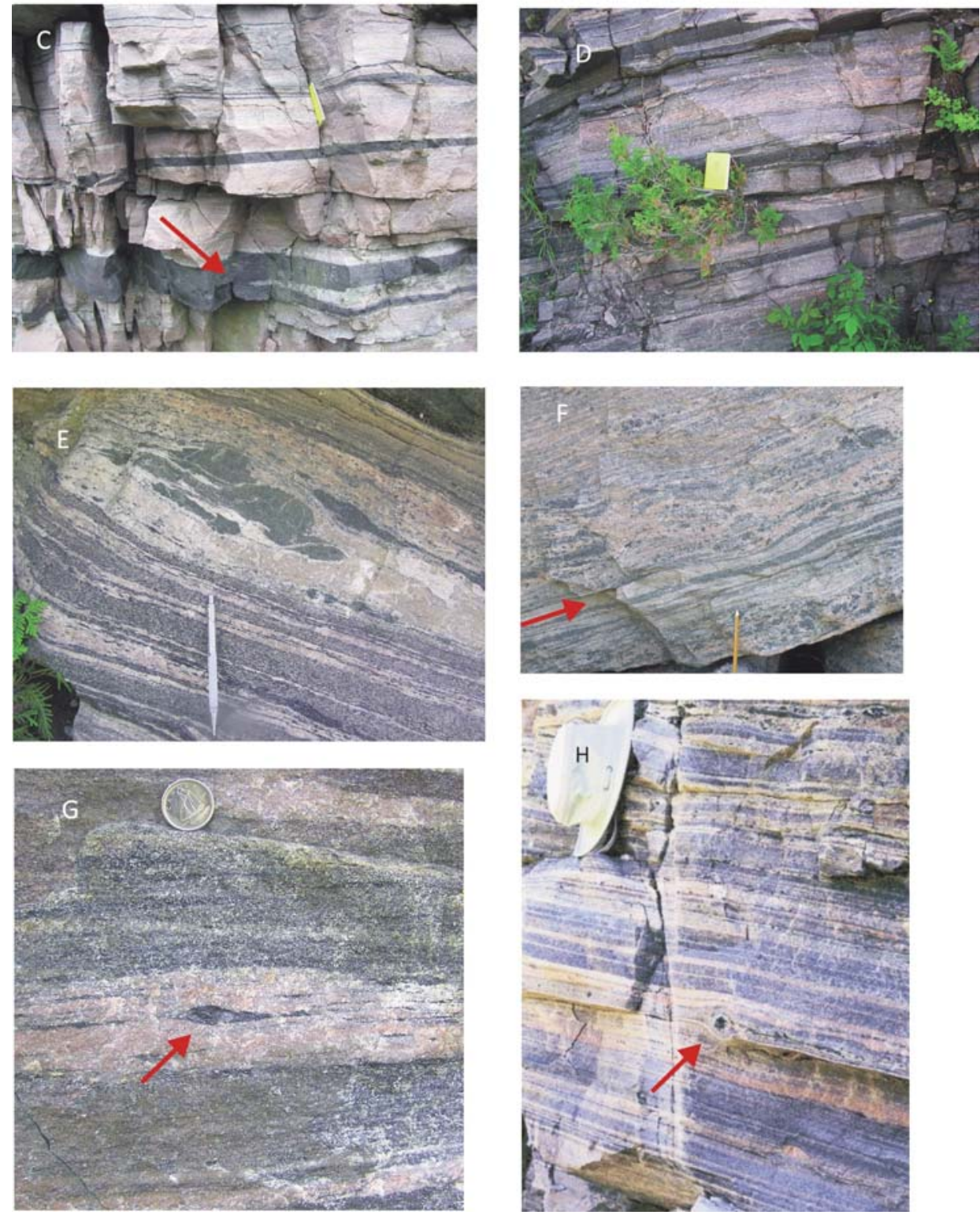

Figure 7. Examples of amphibolite-facies straight gneiss, grey gneiss unit, Muskoka domain. In A-D note extreme attenuation, parallelism and continuity of thin amphibolite layers (black) and thicker layers of granitic, granodioritic to dioritic gneiss. Isoclinal folds outlined by amphibolite layers are common (e.g. arrow in C), the axes of which generally plunge SE parallel to the regional elongation lineation. In $\mathrm{C}$, also note the diffuse white margins adjacent to several amphibolite layers, a result of fluid diffusion between layers of contrasting composition after formation of the high-strain layering. E: Amphibolite-facies high-strain foliation in grey gneiss surrounding central thicker layer of monzonitic gneiss with relict isoclinal fold in clinopyroxenite layer. F: Postmigmatization mylonite layer (arrow) illustrating heterogeneous retrograde strain on the cm scale. G-H: Highstrain tectonic layering flowing around elongate and round porphyroclastic aggregates of $\mathrm{Hbl}$ (arrows). 

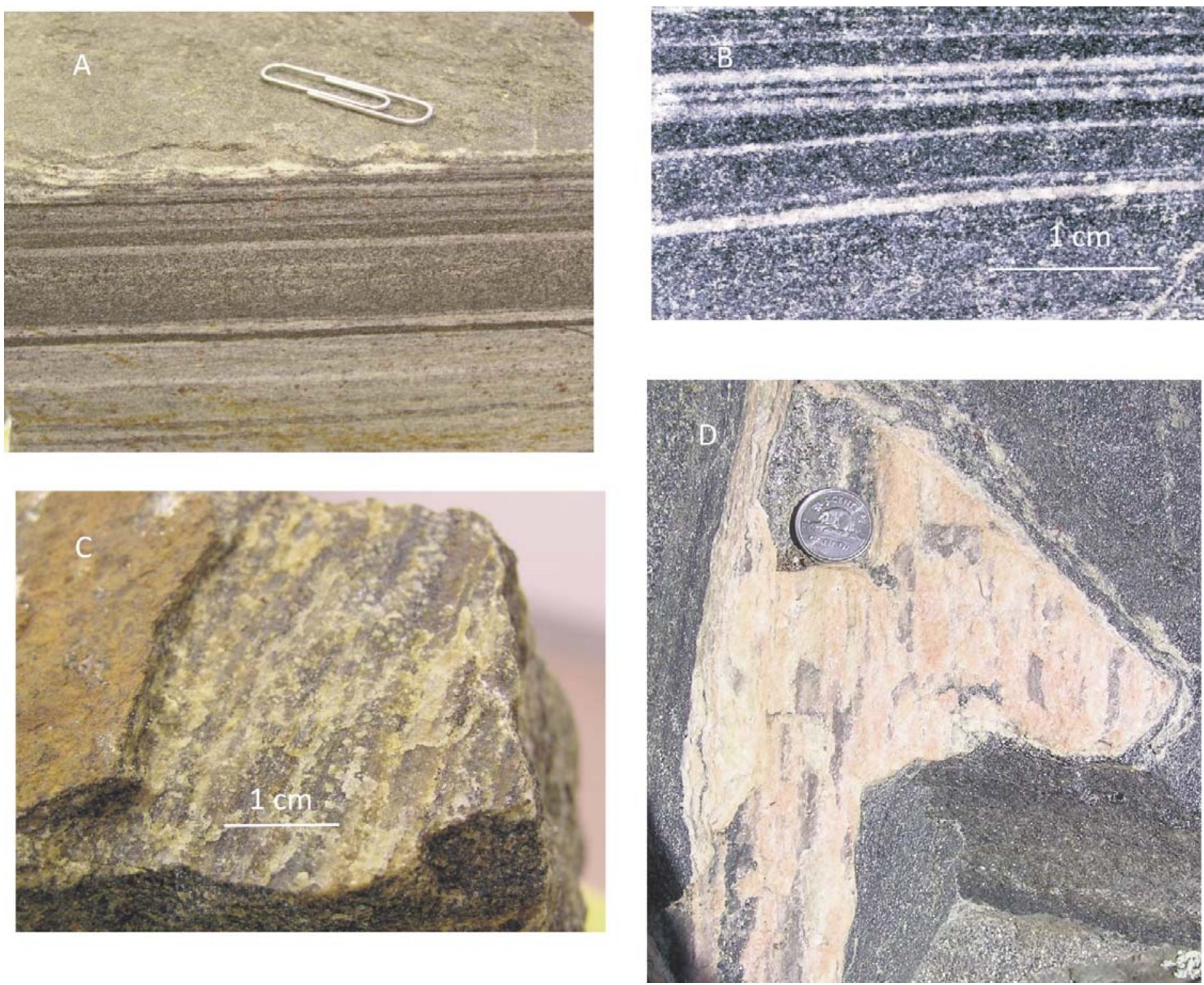

Figure 8. Fabric details in the grey gneiss, Muskoka domain. A: High-strain continuous layering in straight gneiss; the mafic mineralogy (principally $B t$ ) is retrograde, small $G r t$ porphyroblasts in felsic layers are partially replaced by rims of $\mathrm{Pl}$. The upper foliation surface under paper clip is a Bt-rich layer composed of equant grains with their cleavage parallel to the foliation plane, but they do not define a lineation, suggesting Bt crystallization was late. B: Close-up of layering in mafic, amphibolite-facies straight gneiss; the foliation is principally defined by stretched leucosomes, not by a strong crystallographic preferred orientation of $\mathrm{Bt}$ and $\mathrm{Hbl}$ in the mafic layers. C: Close-up of foliation surface in monzodioritic gneiss showing development of L-fabric defined by stretched feldspar aggregates and minor $Q t$ : $\mathrm{Grt}$ is partly replaced by $\mathrm{Pl}$ and surrounded by rims and tails of Bt. Note greenish tint of feldspar, suggestive of a granulite-facies precursor, and variable preservation of the lineation. D: L-fabric on foliation surface in granitic gneiss defined by Qtz ribbons and streaky $K f s$; other foliation surfaces in sample lack a lineation and are coated with Bt. Note pinkish $K f s$ and lack of evidence for granulitefacies precursor.

by a strong crystallographic- or shape-preferred orientation of inequant minerals such as $\mathrm{Hbl}$ and $\mathrm{Bt}$ on a crystalline scale. For instance, Davidson (1984) described the fabrics at the margins of domains in the ORGC as "exhibit[ing] continuous planar foliation due to parallelism of streaky, dark mineral aggregates, flat hornblende-bearing quartzofeldspatbic lenses, feldspar angen distributed on foliation planes, aligned amphibolitic slivers and variably developed compositional layering [...], features [that] combine to give the rocks a streaky or 'shredded' appearance. In places the gneisses are evenly fine grained and well layered $[\ldots]$ straight gneisses $[\ldots$, but $]$ usually $[\ldots]$ grain size is variable and uneven, and layer boundaries are diffuse. [...]. Gneisses with quartzofeldspathic lenses give the impression that they are the flattened equivalents of migmatites whose formerly less regular leucosomes have been attenuated" (p. 276). This is also a fitting descrip- tion of the straight gneiss fabric throughout the Muskoka domain. In addition, we emphasize that in the typical well-layered $\mathrm{S}>\mathrm{L}$ and $\mathrm{S}>>\mathrm{L}$ straight-gneiss tectonites, the shape and/or crystallographic preferred orientation of mineral grains contributes little to the total planar fabric. The foliation is chiefly defined by the gneissic layering and concordant flattened leucosomes (Fig. 8A-B), with the preferred orientation of mineral grains playing a subordinate role. We further note that many foliation surfaces in the straight gneiss are coated with late equant $H b l \pm B t$ grains that exhibit only weak preferred orientation parallel to the layering, and lack shape or crystallographic expression of an L-fabric.

In interpreting the origin and evolution of the straight gneiss fabric at the grain scale, we make the following deduc- 
tions: (a) from the Qtr ribbons and Fsp augen, the presence of narrow mylonite zones and the variable and uneven grain size, we deduce that the high-strain fabric developed by ductile processes such as intracrystalline gliding (Qtz) and sub-grain formation ( $F s p$ ) at high temperature; (b) from the streaky texture of mafic aggregates and the local preservation of relict $P x$ rimmed and replaced by $H b l \pm B t$, we deduce that it is principally a retrograde fabric that developed after peak granulitefacies metamorphism; (c) from the lack of crystallographic preferred orientation of $H b l \pm B t$ we deduce that these minerals underwent post-peak annealing after most deformation had ceased; and (d) from the Hbl $\pm B t$ coatings on some foliation surfaces we deduce there was widespread fluid influx along the foliation after cessation of intense strain. Collectively these suggest three possible origins for the straight gneiss fabric: (i) it is mimetic on the peak-metamorphic granulite-facies fabric, thereby implying that most strain was accrued during thrusting; (ii) it developed as a new high-strain fabric during postpeak amphibolite-facies retrogression/exhumation and extensional collapse; or (iii) it represents some combination of (i) and (ii) that involved variable extensional reworking of older compressional fabrics. Distinction among these possibilities is difficult due to annealing and the Bt $\mathrm{H} \mathrm{H} b$ coatings on many foliation surfaces, and moreover is only feasible where relicts of the original fabric are preserved and post-peak strain markers are available, such as $P /$ pseudomorphs after Grt. Although this issue merits additional study, we conclude from the available data that (iii) is most likely, but the widespread evidence for strongly heterogeneous strain and recrystallization, noted previously, makes it difficult to quantify and generalize in practice.

\section{Cross-folds}

Cross-folds are orogen-perpendicular or orogen-oblique structures that in the Grenville Province mostly have gently SEplunging hinge lines, i.e. approximately perpendicular to the traces of the Allochthon Boundary and the Grenville Front. In the ORGC, they are prominent on a regional scale and deform the stacked allochthons southeast of the Allochthon Boundary, including the contact between structural levels 2 and 3 in the study area, and they also extend to the parautochthon to the northwest (Fig. 9A). The northwest-trending Moon River and Seguin lobes of the Muskoka domain (structural level 3) are the sites of large synformal cross-folds separated by the conjugate Bracebridge antiform in structural level 2 - indeed it is cross-folding that causes the distinctive map pattern. Regional cross-folds have large inter-limb angles and steep axial surfaces (Fig. 9B), lack penetrative axial planar fabrics, and exhibit noncylindrical profiles due to thickness variations around their hinges and plunge variations along their hinge lines. Moreover, on a regional scale their hinge-line traces converge or diverge, exhibit irregular spacing, and vary in trend from SE (orogen-perpendicular) to ESE (orogen-oblique) (Fig. 9A).

In the Muskoka domain, the cross-folds comprise a multiorder fold system, with wavelengths ranging from metre-scale structures visible in outcrop to the $\geq 20 \mathrm{~km}$-scale Moon River, Seguin and Wallace synforms. Moreover, although the majority of metre-scale cross-folds have steep to upright axial surfaces, examples with inclined and recumbent axial surfaces also

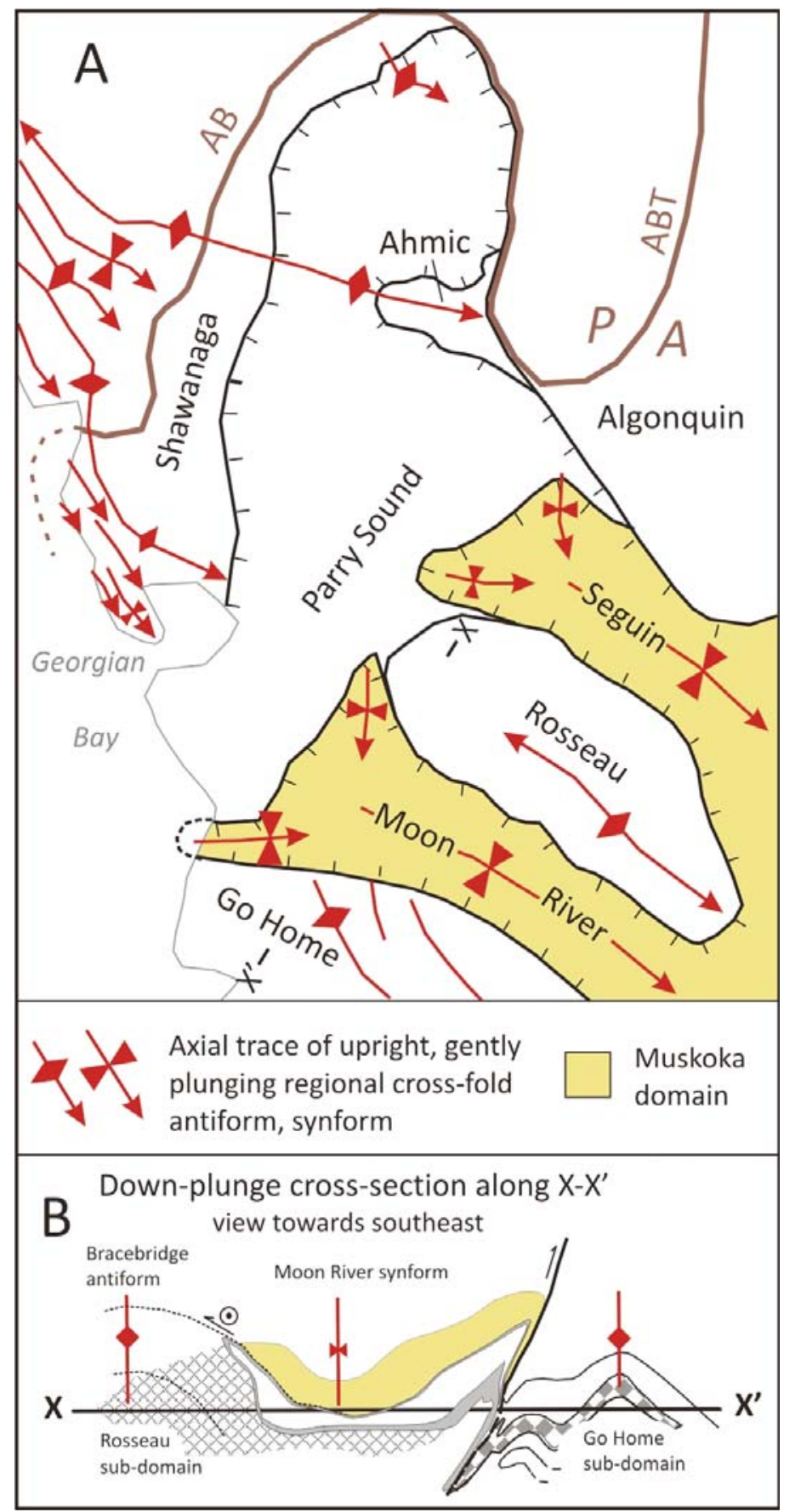

Figure 9. A: Sketch map showing regional distribution of hinge line traces of $\mathrm{km}$ scale cross-folds in the western ORGC (redrawn from Davidson 1984); AB Allochthon Boundary, $P$ - parautochthonous segment, $A$ - allochthonous segment; $\mathrm{X}-\mathrm{X}^{\prime}$ - location of cross-section; $\mathrm{B}$ : Cross-section along $\mathrm{X}-\mathrm{X}^{\prime}$ showing upright axial surfaces and large inter-limb angles of the Moon River synform, Bracebridge antiform, and unnamed antiform in the Go Home domain that are superposed on older recumbent structures. Redrawn from Gower (1992).

occur. Figure 10 illustrates outcrop-scale examples from the Muskoka domain and from the Parautochthonous Belt to the north of the Allochthon Boundary.

The origin of the cross-folds is a long-standing issue. There is agreement they are buckle folds with extension parallel to their hinge lines (Waddington 1973; Schwerdtner and van Berkel 1991; Gower 1992; Klemens 1996; Culshaw 2005; Schwerdtner and Klemens 2008; Schwerdtner et al. 2010a), but 

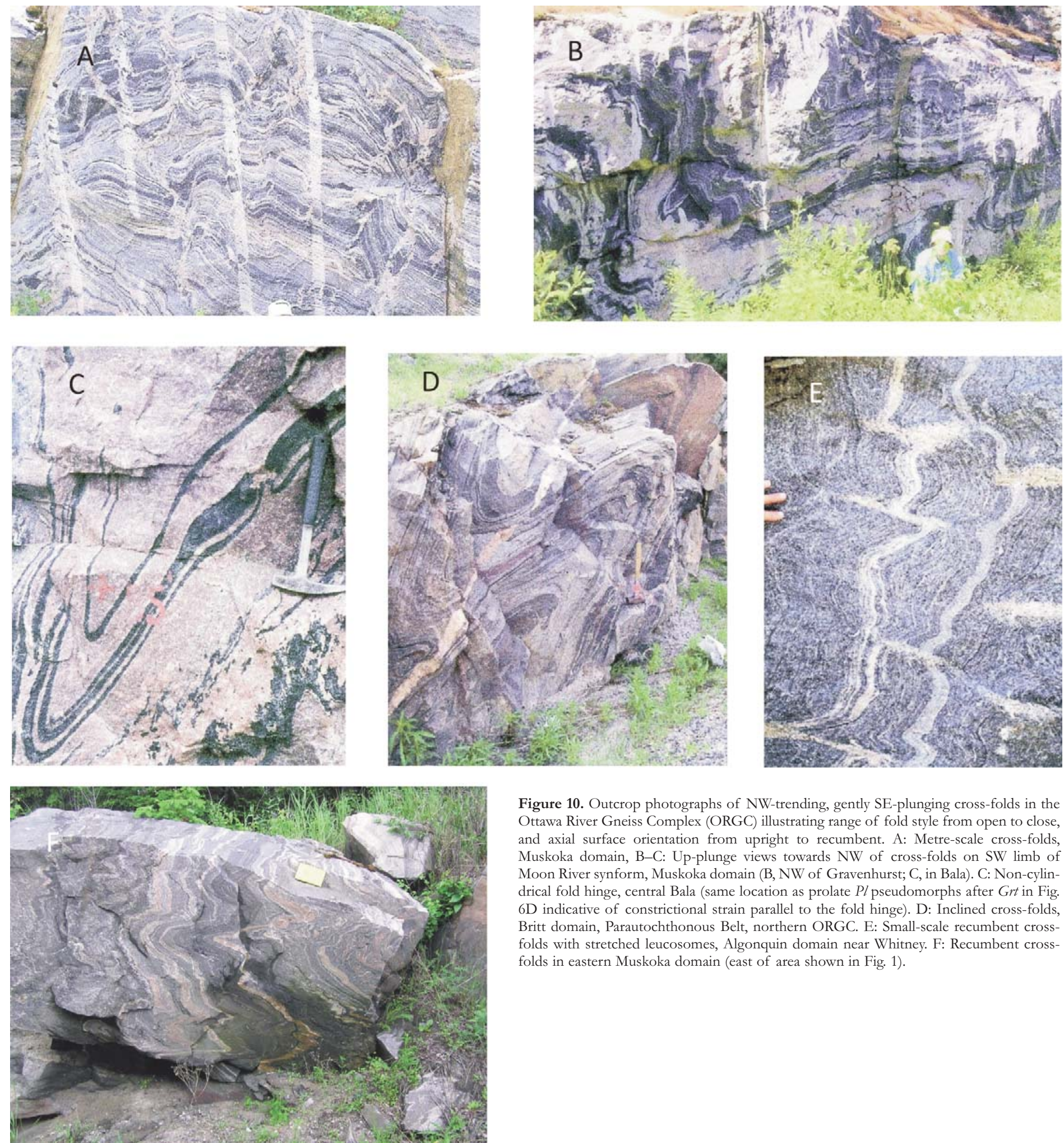

Figure 10. Outcrop photographs of NW-trending, gently SE-plunging cross-folds in the Ottawa River Gneiss Complex (ORGC) illustrating range of fold style from open to close, and axial surface orientation from upright to recumbent. A: Metre-scale cross-folds, Muskoka domain, B-C: Up-plunge views towards NW of cross-folds on SW limb of Moon River synform, Muskoka domain (B, NW of Gravenhurst; C, in Bala). C: Non-cylindrical fold hinge, central Bala (same location as prolate $P l$ pseudomorphs after Grt in Fig. 6D indicative of constrictional strain parallel to the fold hinge). D: Inclined cross-folds, Britt domain, Parautochthonous Belt, northern ORGC. E: Small-scale recumbent crossfolds with stretched leucosomes, Algonquin domain near Whitney. F: Recumbent crossfolds in eastern Muskoka domain (east of area shown in Fig. 1)

no consensus about the deformation regime in which they developed. Our observations throughout the western ORGC indicate the hinge zones of $\mathrm{km}$-scale cross-folds are composed of strongly lineated rocks with $\mathrm{L}>>\mathrm{S}$ mineral-shape fabrics, whereas the limbs are weakly lineated with $\mathrm{S}>>\mathrm{L}$ mineralshape fabrics (Schwerdtner et al. 1977; Schwerdtner 1987). This dichotomy, previously inferred to be a result of superim- posed deformation, is now interpreted in terms of development in a regime of post-peak ductile transtension (Schwerdtner et al. 2014, submitted; Rivers and Schwerdtner 2014).

Since transtension has been relatively neglected in the geological literature until recently, we briefly review the geometric and kinematic principles before discussing its relevance to cross-folds in the study area. Quantitative elaboration of the 
principles was developed by Sanderson and Marchini (1984) and Dewey et al. (1998), and analogue and numerical investigations of transtensional strain were performed by Teyssier and Tikoff (1999), Venkat-Ramani and Tikoff (2002), and Fossen et al. (2013). Applications to natural examples were described by Docka et al. (1998), Krabbendam and Dewey (1998), McFadden et al. (2010), and Fossen at al. (2013).

The upper part of Figure $11 \mathrm{~A}$ is a representation of the model set-up used in most analogue and numerical experiments of ductile transtension, comprising a horizontally layered region of interest between two vertically-sided rigid blocks that diverge at angle $\alpha$. Axial surfaces and hinge lines of transtensional folds developed in subhorizontal layers are steep and subhorizontal respectively, and oblique to the horizontal axes of the far-field stress system. The folds form by shortening (buckling) normal to their hinge lines and extension parallel to their hinge lines, the latter being a hallmark of transtensional folding. Figure 11B-C illustrates the development of cross-folds in rocks previously deformed into recumbent isoclinal folds, such as may occur during assembly of a thrust stack. The hinge lines of these cross-folds are parallel to those formed in horizontally layered crust, but exhibit a range of axial surface orientation from upright to recumbent depending upon the original orientation of the folded layer, another unique attribute of transtensional folding.

On the basis of the magnitude of $\alpha$ and the orientations of the principal farfield stresses $\sigma_{1}$ and $\sigma_{2}$, transtensional deformation is subdivided into two types: wrench-dominated systems $\left(0^{\circ}<\alpha<20^{\circ}, \sigma_{2}\right.$ vertical, $\sigma_{1}$ and $\sigma_{3}$ horizontal), and extensiondominated systems $\left(20^{\circ}<\alpha<90^{\circ}, \sigma_{1}\right.$ vertical, $\sigma_{2}$ and $\sigma_{3}$ horizontal, illustrated in Fig. 11A). An artefact of the changing orientations of $\sigma_{1}$ and $\sigma_{2}$ is that in wrench-dominated systems, transtensional folds are amplified during progressive strain, whereas in extension-dominated systems they are suppressed due to vertical shortening (flattening) with the result that open folds with large inter-limb angles develop.

Two-dimensional surface representations of the deformed region undergoing extension-dominated transtensional strain (Fig. 11D) show that hinge lines of transtensional folds rotate towards the extension direction with increasing deformation, with the result that the divergence angle after several increments of strain $(\theta)$ is larger than that for a single increment $(\alpha)$.

In applying these principles to the large-scale first-order cross-folds in the ORGC, we note that they are developed in highly attenuated straight gneiss (Fig. 7), preserve evidence for constrictional strain parallel to their hinge lines ( $\mathrm{L}>>$ S; Schwerdtner et al. 1974, 1977; Schwerdtner 1987), and have large inter-limb angles (Fig. 9B), all compatible with a transtensional setting. Moreover, mesoscopic second-order cross-folds with parallel hinge lines exhibit a range of axial surface orientation from vertical through inclined to recumbent (Fig. 10), also compatible with the analysis of Fossen et al. (2013) and not readily explained by other folding regimes. In summary, the authors consider the interpretation that the cross-folds developed in a regime of post-peak, extension-dominated ductile transtension to be compelling. This conclusion, including an explanation for the $\mathrm{L}>>\mathrm{S}$ fabrics in their hinges and the $\mathrm{S}>>\mathrm{L}$ fabrics in their limbs, is developed in greater detail in a companion study by Schwerdtner et al. (submitted).

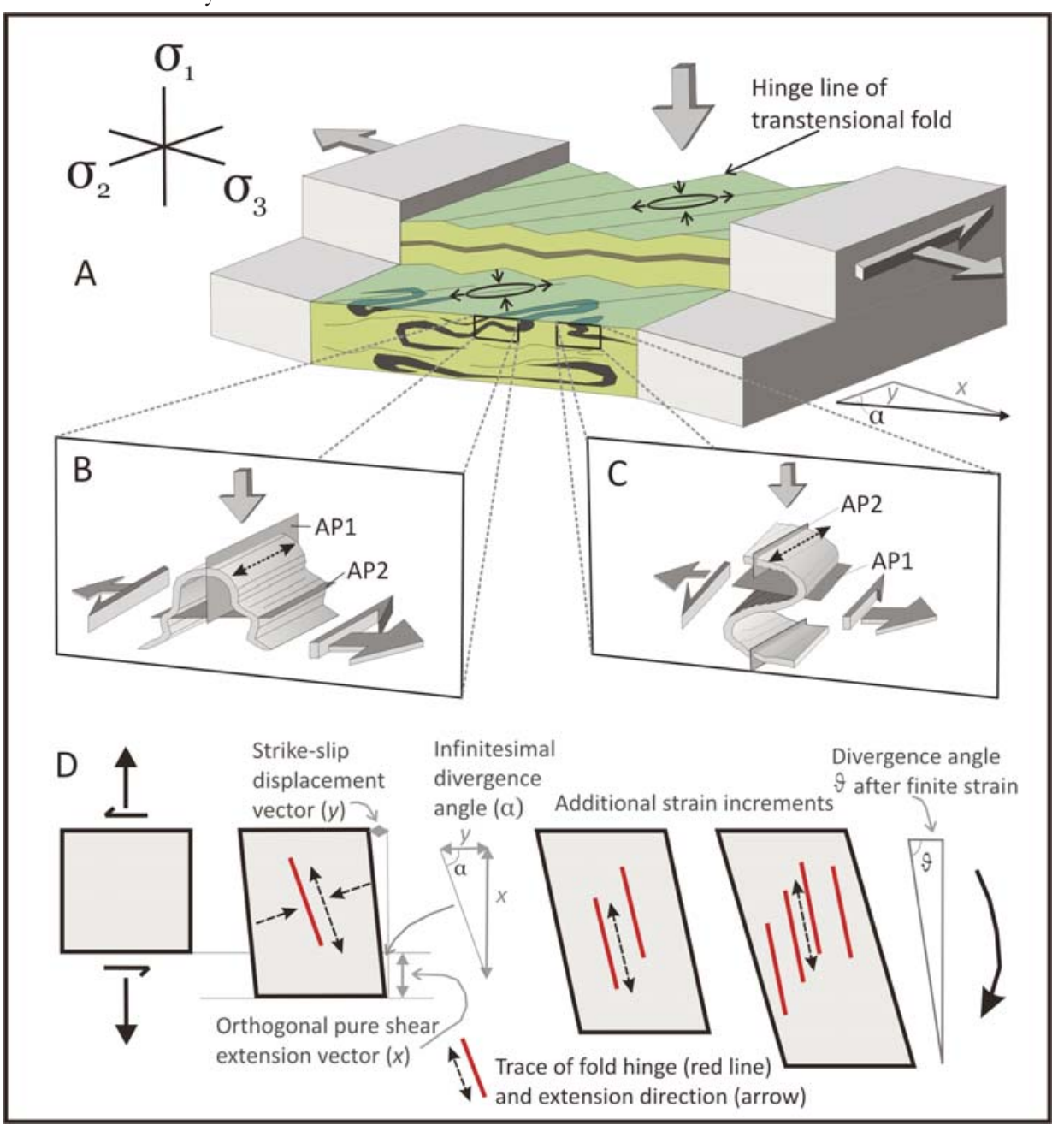

Figure 11. A: Typical model set-up for extension-dominated sinistral transtension of subhorizontally layered crust between vertically-sided rigid blocks with divergence angle $\alpha$, and the extension $(x)$ and wrench $(y)$ parts of the transtension tensor. Upper part of figure shows development of transtensional folds with subhorizontal hinge lines, steep axial surfaces, and large inter-limb angles. B-C: Enlargements of lower part of figure showing (B) refolding of pre-existing recumbent limbs of isoclinal folds, giving rise to transtensional folds with steep axial surfaces (AP1), the steep limbs of which may later become refolded by recumbent folds (AP2); and (C) refolding in the steep hinge regions, where superimposed transtensional folds have recumbent axial surfaces (AP1) that may later be refolded by folds with steep axial surfaces (AP2). D: Two-dimensional plan-view sketches showing the extension $(x)$ and wrench $(y)$ parts of extension-dominated transtension, the infinitesimal divergence angle $\alpha$, and the finite divergence angle $\theta$ after two additional increments of sinistral transtensional strain. Transtensional folds develop by buckling perpendicular to fold hinge lines (due to wrench part of deformation) and extension parallel to their hinge lines (due to extension part of deformation), and orientations of the shortening and extension directions after the first strain increment are shown by dashed black arrows. With successive strain increments, their hinge lines rotate towards the principal extension direction (curved black arrow at right hand side). A-C modified from Fossen et al. (2013). 


\section{Boudinage}

Straight gneiss with a strongly attenuated fabric, a signature of the Muskoka domain (Fig. 7), implies very high extensional strain in the plane of the foliation and is compatible with the observed wide range of boudinage-related structures. Some general features of boudinage and associated pinch and swell structures are shown in Figure 12, and metre- to cm-scale examples from the Muskoka domain are shown in Figure 13. Since boudinage is a scale-invariant process, such structures may also be anticipated in thicker packages of multi-layers at larger scales (discussed below).

Although in principle boudinage in the Muskoka domain could have occurred during either crustal thickening or extension, cases in which the high-strain fabric surrounding the boudin is amphibolite facies, but the boudin contains evidence for relict granulite-facies assemblages (Figs. 5, 7E, 13E-F), support the interpretation that it principally occurred after the metamorphic peak during retrogression and decompression.

\section{Foliation Boudinage}

Foliation boudinage (Fig. 12C) develops when a visually homogeneous foliated or gneissic rock is extended parallel to the foliation beyond its yield strength resulting in brittle-ductile failure, the fracture porosity generated typically being filled with leucosome in high-grade rocks giving rise to pucker structures (Ward et al. 2008). Leucosome-filled pucker structures are common in the Muskoka domain and some examples are shown in Figure 14. Again, the question arises whether the structures developed during thrusting or extension. That all the leucosomes illustrated in Figure 14 are undeformed suggests they are late, an inference supported by the presence of $\mathrm{Hbl} \pm \mathrm{Bt}$ in the attenuated fabric. Moreover, most leucosomes contain peritectic $\mathrm{Hbl}$, implying $\mathrm{H}_{2} \mathrm{O}$-saturated melt formed by reaction (3) was either still present after the metamorphic peak or was generated during extension. The occurrence of $O p x$ bearing leucosomes (Fig. 14C) is relatively rare, but may indicate that some melt produced by dehydration melting by reaction (2) at the metamorphic peak was still present and migrated into dilational zones during extension.

\section{Foliation Megaboudins}

Kilometre-scale major lenticular structures, first defined and described in the Muskoka domain by Schwerdtner and Mawer (1982), were interpreted as foliation megaboudins by Schwerdtner et al. (2014). Erosion surface slices through these gently dipping elliptical structures appear as oval foliation traces with short-axis dimensions of $20-30 \mathrm{~km}$ and long-axis dimensions of $50-60 \mathrm{~km}$; i.e. they are of crustal scale. Two examples were described by Schwerdtner et al. (2014), of which one, the Germania foliation megaboudin, is situated in the study area and illustrated in Figure 15. In 3-D, it has the shape of an inclined disc plunging shallowly to the east (Schwerdtner et al. 2014).

In addition to the implication from its disc shape of significant attenuation of the gneissic foliation on a large scale, the lithologies within the Germania foliation megaboudin also preserve evidence of the ductility contrast that gave rise to the boudinage. The core of the megaboudin is composed of granulite-facies rocks with weak strain fabrics (Fig. 16A-B), whereas the rim consists of amphibolite-facies rocks with high-strain

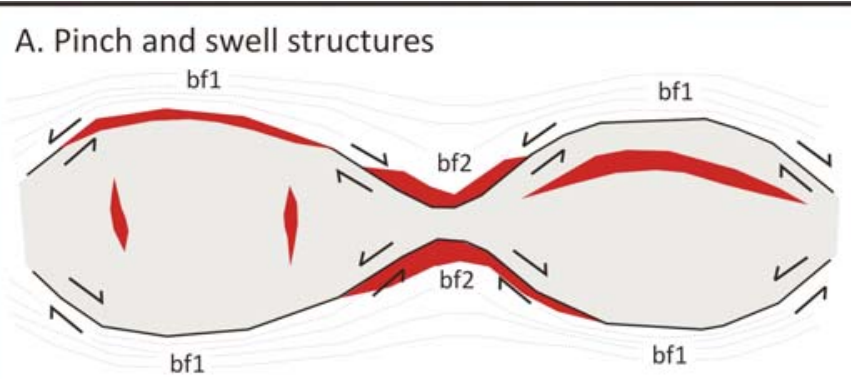

B. Boudins

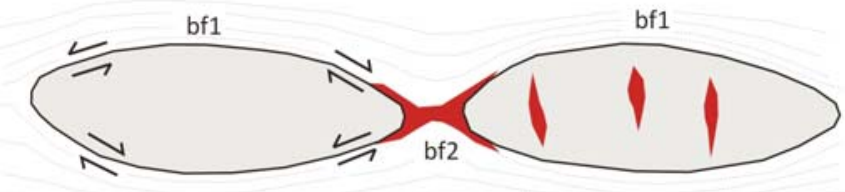

\section{Foliation boudins}
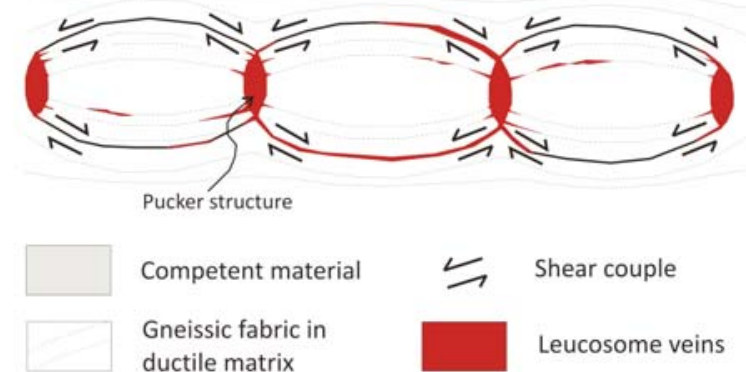

Figure 12. Sketches of (A) pinch-and-swell structures, (B) lenticular boudins, and (C) foliation boudinage. Local shear-sense reversal at opposite ends of boudins is due to differential attenuation between the relatively stiff boudin and ductile matrix. In (A-B) two types of extensional bending fold (bf) in the ductile matrix are shown. bf1 have large inter-limb angles resulting from moulding of the stretched matrix around the curved surface of the boudin, whereas bf 2 are lower strain structures with smaller inter-limb angles that form in the neck regions between adjacent boudins, exhibit marked layer thickening in their hinge zones, and die out away from the boudin axis. Lateral change in layer thickness associated with bf1 and bf2 folds provides a measure of local attenuation (see text). In foliation boudinage (C), pucker structures develop despite the lack of obvious lithological or competency contrast between the material forming the boudin and the matrix. Possible locations of leucosome veins are shown in each case. Modified from Schwerdtner et al. (2014).

fabrics (Fig. 16C). This suggests the foliation megaboudin developed by reworking of a pre-existing granulite-facies fabric during retrogression, with reaction weakening under suprasolidus conditions reducing viscosity and permitting profound attenuation of the fabric at the margins of the structure. In this context, the weakly strained core is interpreted as a remnant of the peak-Ottawan granulite-facies fabric that escaped post-peak retrogression. Moreover, this may also provide an explanation for the preservation of other weakly strained granulite-facies features in the southwest Muskoka domain, such as those described by Timmermann et al. (2002) and illustrated in Figure 16D. From our reconnaissance work in the Algonquin and Muskoka domains we have tentatively defined several foliation megaboudins (Schwerdtner et al. 2014; Rivers and Schwerdtner 2014), and we consider them to be a signal of the coeval retrogression and attenuation of the peak Ottawan granulite-facies crust.

In contrast to the shapes of typical mesoscopic foliation boudins (e.g. Figs. 12C, 14A-C), the neck regions of the Ger- 

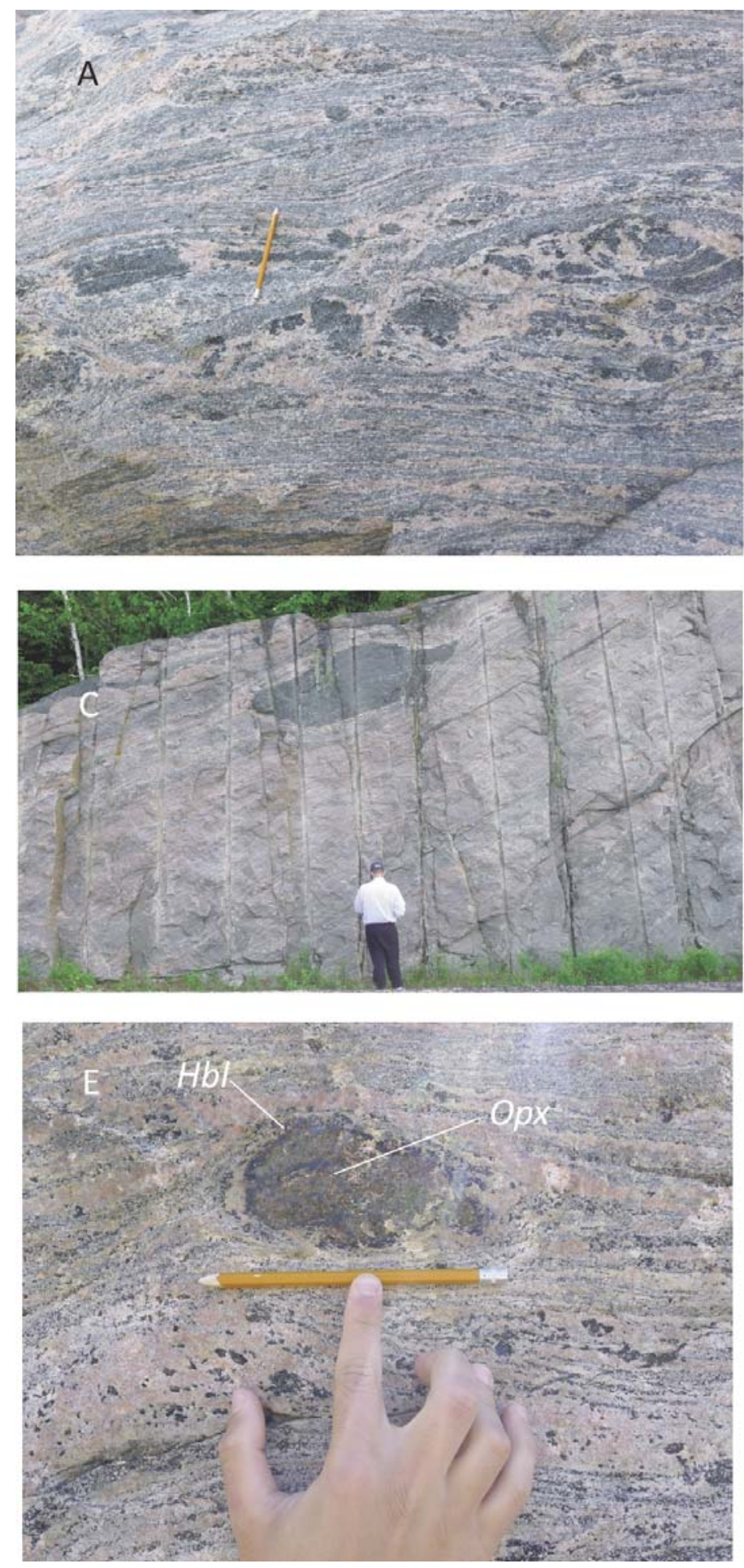
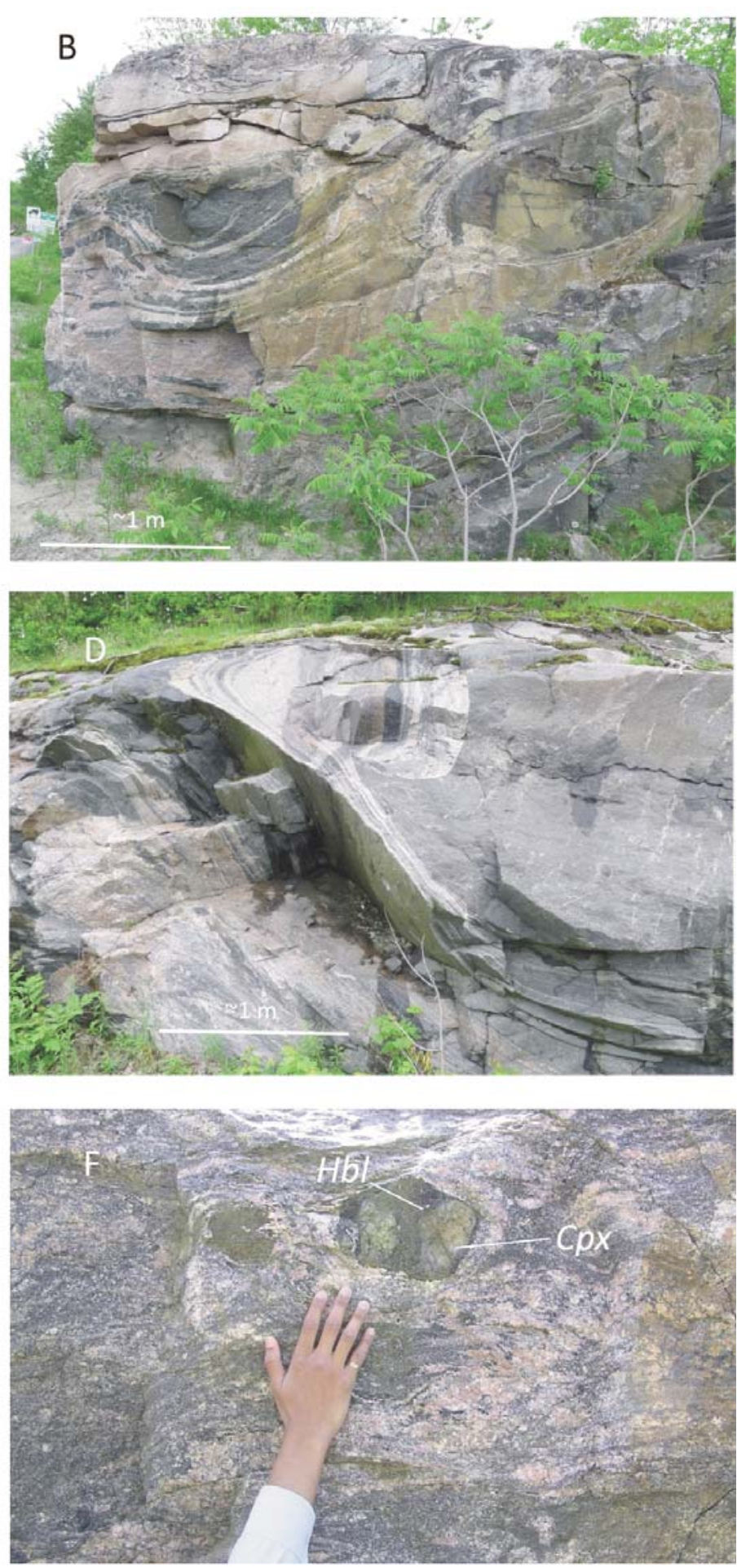

Figure 13. Metre- and centimetre-scale boudinage in amphibolite-facies grey gneiss, Muskoka domain. A: Hbl-bearing leucosome surrounding boudins during break-up of amphibolite layers; B-C: Differing degrees of separation between adjacent boudins; D: 'Fishmouth' boudin in which the boudin margin undergoes attenuation with adjacent matrix after formation; softening and attenuation of the boudin margin are driven by retrogression. Note thin leucosome-filled extensional fractures in boudin at high angle to the external foliation; E-F: Evidence that boudinage was associated with retrogression of the gneissic fabric surrounding the boudin, specifically relict $O p x$ in the core of a small boudin with a $\mathrm{Hbl}$ rim in E, and clinopyroxenite boudin partially replaced by amphibolite along a fracture at high angle to the gneissic layering in $\mathrm{F}$, implying brittle extension was accompanied by retrogression of $\mathrm{Cpx}$ to $\mathrm{Hbl}$. 

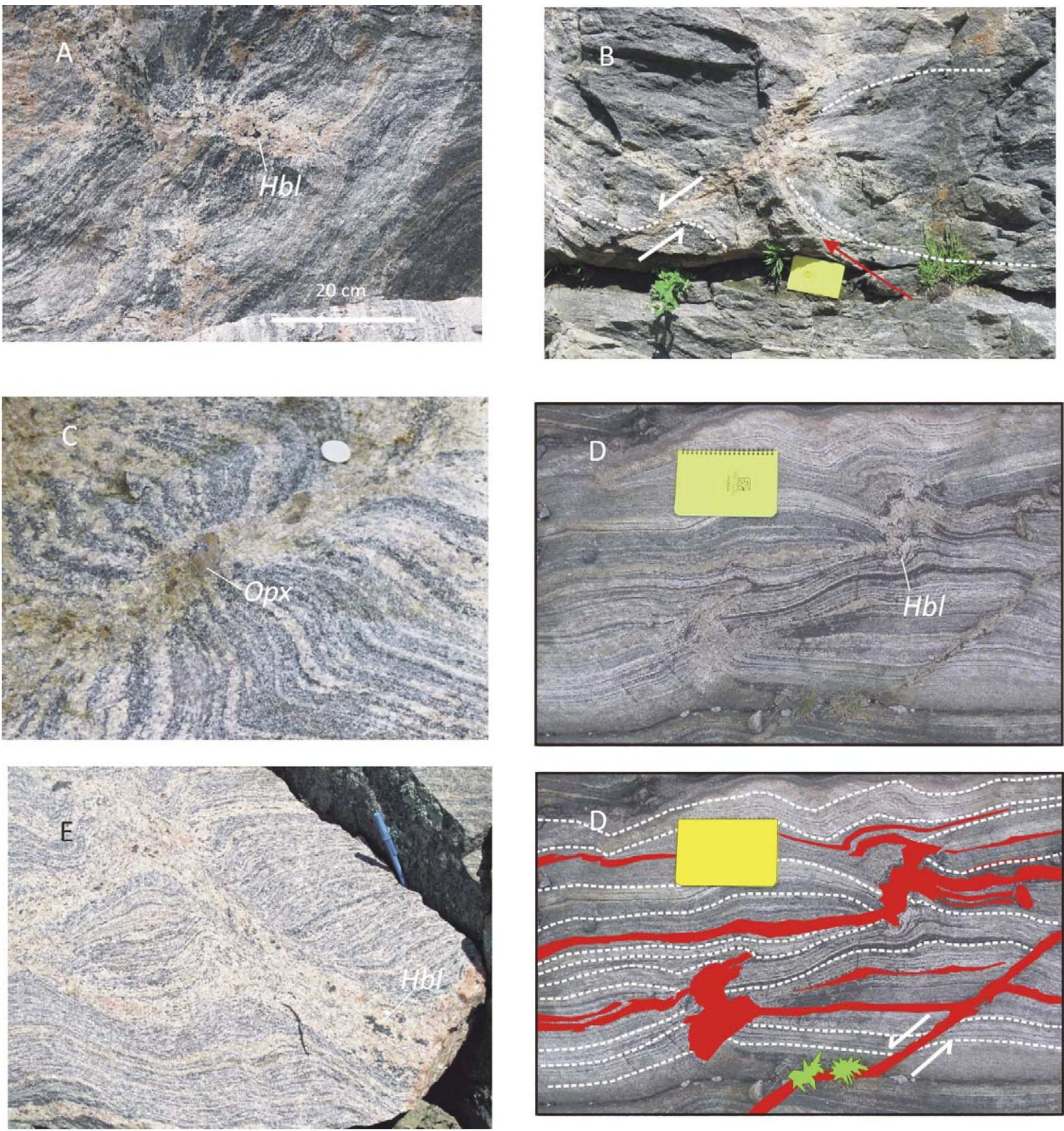

Figure 14. Field photographs of small-scale foliation boudinage showing pucker structures, A-D in grey gneiss from the Muskoka domain, E from the Parry Sound domain. A-C: Spidery $\mathrm{cm}$-scale granitoid leucosomes in boudin necks are not continuous for more than a few $\mathrm{cm}$ suggesting local derivation, and may be sites of melt loss. In (B) foliation is enhanced with dashed white lines and minor extensional offset is shown (half arrows); localized high strain foliation (red arrow) defines margin of foliation boudin. Leucosomes in $\mathrm{A}-\mathrm{B}$ have peritectic $\mathrm{Hbl}$, those in $\mathrm{C}$ have peritectic $\mathrm{Opx}$; $\mathrm{Hbl} \pm \mathrm{B} t$ present in foliation in all cases. D (shown without and with interpretation): Leucosome with peritectic $\mathrm{Hbl}$ in the neck regions between foliation boudins, parallel to the foliation, and along a discordant vein that exhibits normal-sense offset (half arrows). In contrast to $(\mathrm{A}-\mathrm{C})$, at least some of the leucosome was derived from outside the field of view. E: Boudin surrounded by leucosome with peritectic $\mathrm{Hbl}$, possible small-scale analogue for an early stage of formation of foliation megaboudins (see text). 


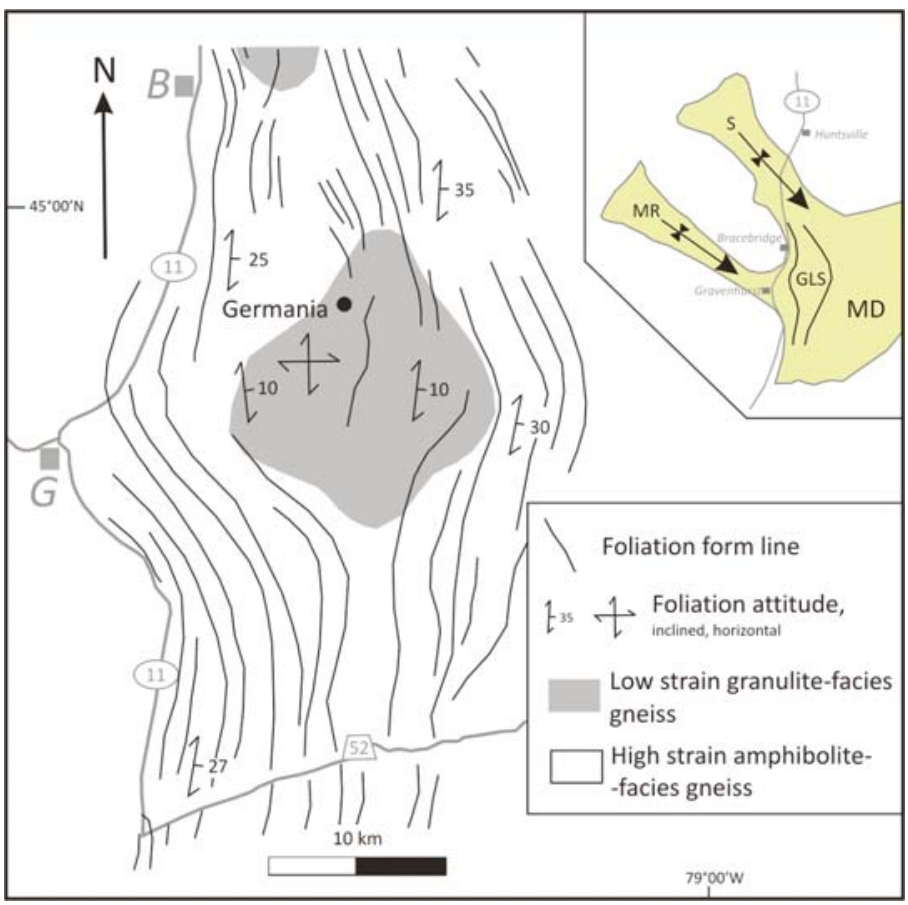

Figure 15. Sketch map of the Germania foliation megaboudin or Germania lenticular structure (GLS), showing its discoid shape in 2-dimensions defined by structural form lines, with the central area underlain by weakly strained granulite-facies rocks and the margins by high-strain amphibolite-facies gneiss. The granulite-facies core of the structure is a peak-Ottawan metamorphic relict; foliation megaboudinage and formation of the high-strain amphibolite-faces gneiss at the margins of the structure took place during post-peak exhumation and retrogression. Location of granulite at northern margin of map from Timmermann et al. (2002). B - Bracebridge, G - Gravenhurst (modified from Schwerdtner et al. 2014). Inset figure shows location of the GLS within the Muskoka domain (MD) and its relation to the Moon River (MR) and Seguin (S) synforms. Modified from Rivers and Schwerdtner (2014).
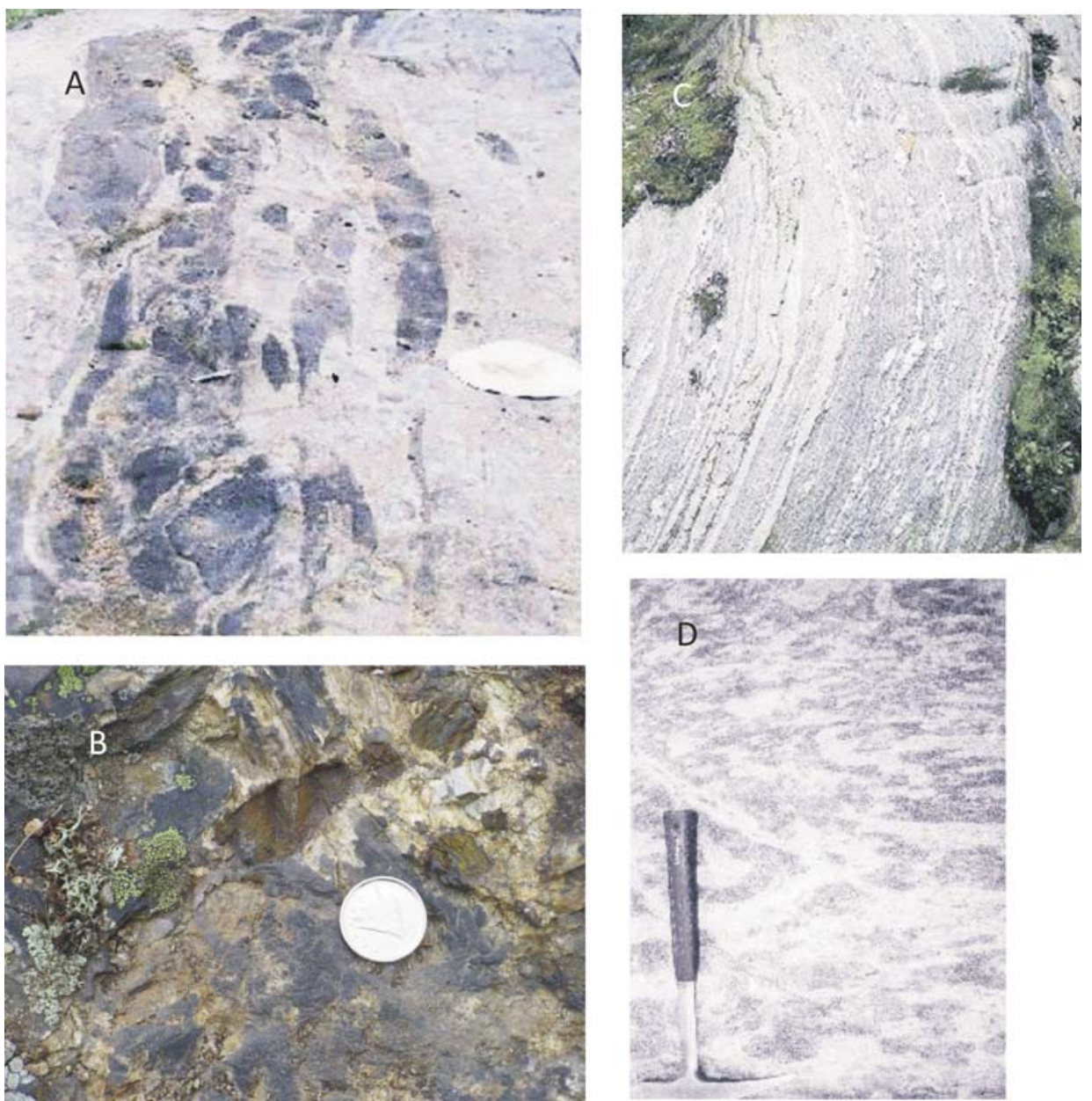

Figure 16. A-C: Comparison of structures and mineral assemblages developed in the core (A-B) and margin (C) of the Germania foliation megaboudin. The core exhibits coarse-grained granulite-facies mineral assemblages and weak strain fabrics, whereas the margin consists of high-strain amphibolite-facies gneiss. B: 1-2 cm, undeformed orthopyroxene megacrysts in metamonzonite in the core of the megaboudin. D: Undeformed granulite-facies enclave with anastomosing network of Opx-bearing leucosome. A and C from Schwerdtner et al. (2014), D from Timmermann et al. (2002). mania foliation megaboudin are not the sites of spidery leucosome bodies or pucker structures at high angle to the foliation. This may suggest that leucosome at the terminations of the megaboudin formed early and became attenuated with the amphibolite-facies foliation, as seen in the mesoscopic examples illustrated in Figures $7 \mathrm{E}$ and $14 \mathrm{E}$. In summary, the orientation, shape, size and mineral assemblages of the Germania foliation megaboudin imply post-peak, N-S stretching and ductile attenuation of crustal scale in the Muskoka domain, i.e. orogen-perpendicular extension during exhumation and orogenic collapse.

\section{Large-scale Extensional Bending Folds}

Boudinage implies the ductile layering surrounding the boudin is attenuated, forming extensional bending folds of opposing curvature surrounding the boudin itself and within the boudin neck region (bf1 and bf2; Fig. 12). Examples of large-scale $(\geq 10 \mathrm{~km})$ extensional bending folds in the Parry Sound domain of the ORGC were given by Schwerdtner et al. (2014). We describe an example defined by the NWtrending boundary between structural levels 2 and 3 here, which separates the antiformal, granulite-facies Rosseau subdomain (structural level 2) from the synformal Seguin subdomain (structural level 3). The non-cylindrical bf2 extensional bending fold is termed the Camel Lake synform (Fig. 17). The folded foliation defining the Camel Lake synform is an 
amphibolite-facies high-strain fabric, locally straight gneiss, providing qualitative support for an origin by post-peak retrogression and attenuation.

The minimum magnitude of the NW-SE ductile extension associated with the development of the Camel Lake synform and adjacent antiforms can be estimated from the map pattern and $\mathrm{km}$-scale UTM grid in Figure 17 and assuming a plunge of $20^{\circ} \mathrm{ENE}$ (Lumbers and Vertolli 2000a). In the horizontal plane, the apparent thicknesses in the core of the synform and adjacent antiform are $\sim 5.5 \mathrm{~km}$ and $0.5 \mathrm{~km}$ ( $t$ and $t^{\prime}$, Fig. 17), corresponding to true thicknesses of $\sim 1.9$ and $0.2 \mathrm{~km}$ respectively, indicating the thickness of the antiformal hinge zone around the barrel-shaped megaboudin was reduced by $\sim 90 \%$. The amount of orogen-perpendicular extension on the $10 \mathrm{~km}$ scale implied by this attenuation (double-headed red arrow; Fig. 17) can be constrained within broad limits assuming the rock volume and thickness of the hinge zone of the Camel

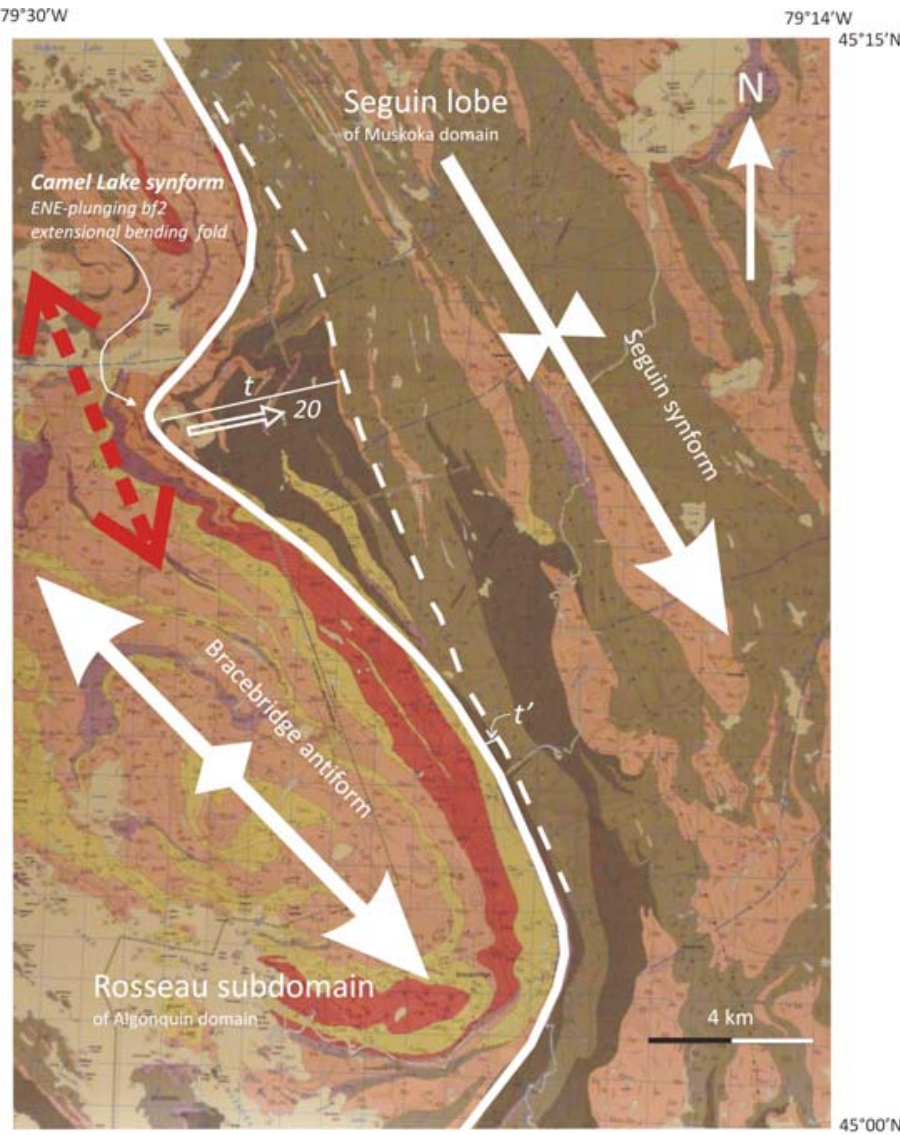

Figure 17. Photograph of part of a 1:50,000 scale geological map with overlain line-work showing the Camel Lake synform, a bf2 extensional bending fold outlined by the thick solid white line marking the contact between the granulite-facies Rosseau subdomain and amphibolite-facies Seguin subdomain (structural levels 2 and 3, respectively). The thinner dashed white line marks the approximate eastern limit of the Camel Lake synform in the Seguin subdomain, illustrating the extreme thickening in the fold hinge and non-cylindrical geometry characteristic of bf 2 folds. The boundary between the Seguin and Rosseau subdomains dips $\sim 20-30^{\circ}$ ENE in most of the map area, and the Camel Lake synform plunges at $\sim 20$ $-->070^{\circ}$. The hinge region of the synform is a low-strain window, preserving isoclinal folds in the mafic grey gneiss unit (dark brown) that probably developed during prograde thrusting and crustal thickening and were refolded during post-peak boudinage and formation of the Camel Lake synform. The red NW-SE-trending double-headed arrow indicates the orogen-perpendicular extension direction implied by the Camel Lake extensional bending fold. Part of the Bracebridge sheet (NTS $31 \mathrm{E} / 3$; Lumbers and Vertolli 2000a; UTM km grid for scale); map reproduced by permission of the Ontario Geological Survey.
Lake synform remained constant during extensional bending (Schwerdtner 1970, 1977). Assuming average thinning of 50\% on the $10 \mathrm{~km}$ scale, for axisymmetric biaxial boudinage NWSE bulk extension would have been $\sim 40 \%$, whereas for triaxial boudinage (typical of the field area; Schwerdtner et al. 2014) NW-SE bulk extension may have exceeded $200 \%$.

Also apparent from Figure 17 is the preservation of isoclinal folds in mafic grey gneiss in the core of the Camel Lake synform that are refolded by the synform itself. This supports our contention discussed above that the thicker crustal section in the core of the synform is a low-strain window. Hence, we infer the isoclinal folds developed during thrusting and prograde metamorphism, whereas the refolding took place during post-peak retrogression and triaxial boudinage.

In summary, we conclude the Camel Lake synform provides evidence for very substantial attenuation of the base of the Muskoka domain during formation of the regional postpeak amphibolite-facies foliation. The orientation and location of the boudinage and extensional bending fold imply the more competent, granulite-facies structural level 2 was extended in a NW-SE, orogen-perpendicular direction probably by $>200 \%$, and the overlying more ductile Muskoka domain in structural level 3 underwent local attenuation by as much as $90 \%$ in the barrel-shaped bf1 bending folds, thereby collectively providing evidence for important post-peak orogen-perpendicular crustal extension and thinning on the $10 \mathrm{~km}$ scale.

\section{Extensional Fault Propagation Folds and Granite Pegmatite Dykes}

Fault propagation folds (FPFs) develop at the tips of active brittle faults (Fig. 18), and until recently, extensional FPFs were only known from unmetamorphosed sedimentary rocks (e.g. Schlische 1995; White and Crider 2006; Ferrill et al. 2012). The first report of extensional FPFs in gneissic rocks was by Schwerdtner et al. (2014) who investigated their relationship to late cross-cutting pegmatite dykes in the ORGC.

Since FPFs are brittle-ductile structures that develop in rocks with significant strength, their presence in plastically

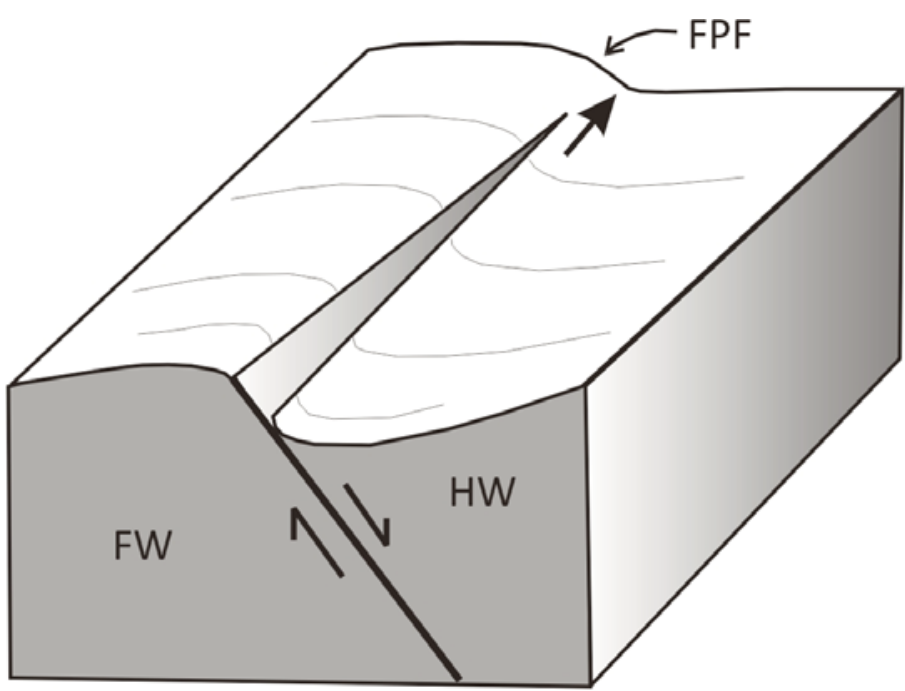

Figure 18. 3-D sketch showing the lateral propagation of an extensional fault leading to the formation of a fault propagation fold (FPF) with a subhorizontal axis. FPFs develop from the distribution of elastic stresses at the fault tip due to the scissor movement of the fault, and their formation is restricted to brittle-ductile rocks. FW - footwall, HW - hanging wall. Redrawn from White and Crider (2006). 

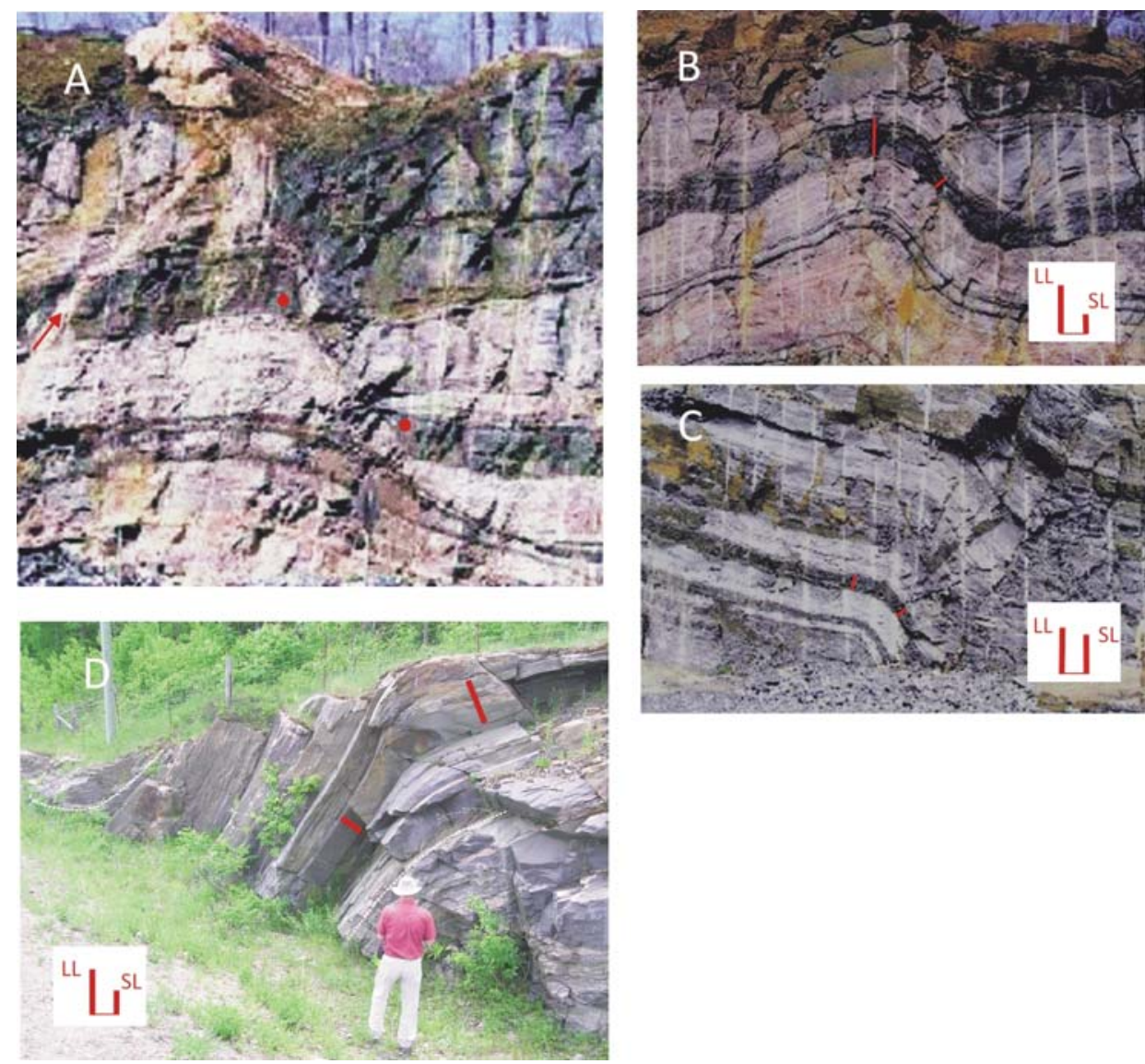

Figure 19. SE-dipping extensional fault propagation folds (FPFs) in the Ottawa River Gneiss Complex. A: FPF transected by an extensional fault parallel to the short monoclinal limb that causes visible offset of amphibolite layer (red dots mark piercing points). Red arrow points to NW-dipping granite pegmatite dyke oriented parallel to the axial surface of the FPF in the footwall. B-D: FPFs in which the short monoclinal limbs are attenuated, but there is no fault. Red bars show thicknesses of folded layers on the long limbs (LL) and short limbs (SL), and their relative lengths are compared at the bottom of each image. Attenuation in the short monoclinal limb ranges from $100 \%$ in $\mathrm{A}, \sim 60 \%$ in $\mathrm{B}, \sim 45 \%$ in $\mathrm{D}$, to $\sim 18 \%$ in C. Foliation is highlighted by dashed white line in D. A-C modified after Schwerdtner et al. (2014).
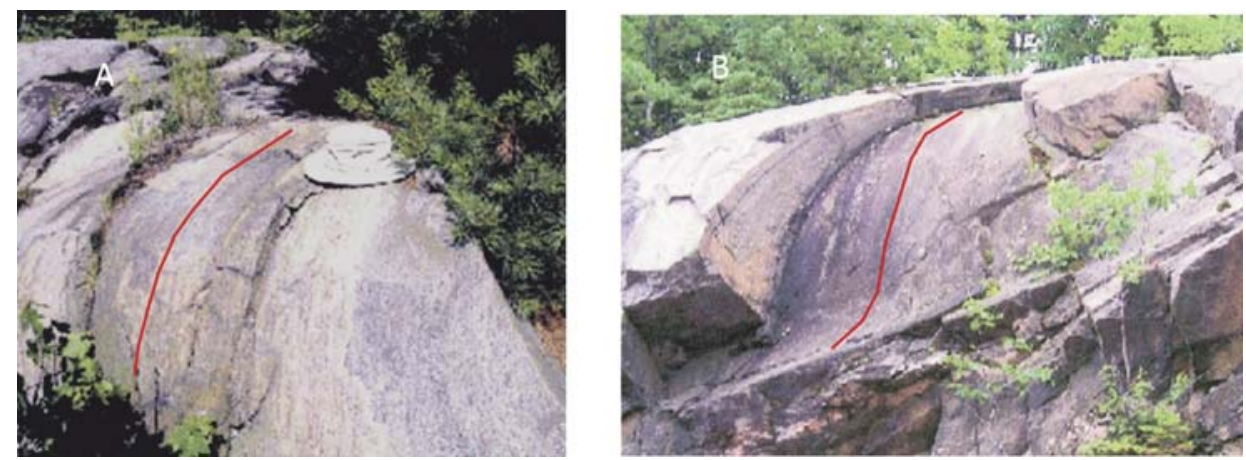

Figure 20. Fault propagation folds in the Muskoka domain showing down-dip lineations (highlighted by thin red lines) on the short monoclinal limbs. Slightly modified from Schwerdtner et al. (2014).

deformed high-grade gneiss of the ORGC implies they formed late in the history of the gneiss complex, after the high-grade rocks had undergone significant exhumation and cooled and strengthened. Our field work indicates that extensional FPFs are common in the ORGC and some examples and characteristic features are shown in Figures 19-20. In general, their hinge zones form arcs or quasi-chevron shapes and they exhibit monoclinal symmetry due to dissimilar limb lengths. The short limbs of most FPFs dip moderately to steeply to the SE, may be significantly thinned compared to the long limbs (Fig. 19), and are the sites of approximately down-dip lineations defined by finegrained stretched mineral aggregates that are subparallel to the regional L fabric (Fig. 20). There is a visual correlation between the strength of the lineation and the degree of attenuation in the short limb of the FPFs (Fig. 19), suggesting that in some FPFs the regional extension lineation was enhanced during formation of the FPF by flexural shear between adjacent layers (e.g. Hobbs et al. 1976). This conclusion is compatible with their development spanning the ductile-brittle transition.

The absolute time of formation of extensional FPFs such as those illustrated in Figures 19-20 cannot be readily determined, but Schwerdtner et al. (2014) showed that the short limbs of some FPFs are the sites of cross-cutting, undeformed to weakly deformed granite pegmatite dykes from $<1-15 \mathrm{~m}$ wide, the emplacement of which is considered to closely approximate the time of FPF formation. They referred to these as set- 1 dykes and some examples from the Muskoka domain are shown in Figure 21. A later set of granite pegmatite dykes that is undeformed and in which individual dykes are generally thinner $(<50 \mathrm{~cm})$, was emplaced parallel to the NW-dipping axial surfaces of the FPFs. Examples of these set- 2 dykes are illustrated in Figure 22.

Figure 23 is a sketch showing the geometric relations of set- 1 and set- 2 dykes and extensional FPFs and their inferred emplacement mechanisms. We envisage a regime of limited brittle-ductile extension during gravitationally-driven orogenic collapse with dyke emplacement driven by magmatic overpressure at depth. As noted previously, $\mathrm{U}-\mathrm{Pb}$ zircon crystallization ages of the pegmatite dykes in the ORGC, some of which were located in the monoclinal limbs of FPFs, are $\sim 1000-990 \mathrm{Ma}$ (Corrigan et al. 1994; Bussy et al. 1995), compatible with the deduction of late-orogenic emplacement.

Schwerdtner et al. (2014) compiled orientation data for poles to $>1200$ granite pegmatite dykes from the Algonquin and Muskoka domains of the ORGC and the northern margin of the $\mathrm{CAB}$ that yielded a maximum in the SE quadrant, implying most dykes have NE-SW strikes and NW dips respectively. From these data, they showed that the set- 1 and set- 2 dykes are principally SE- and NW-dipping respectively. In Figure 24A-B, we present new data for the orientations of poles to $>500$ mostly set- 2 pegmatite dykes in the map area and adjacent parts of the Muskoka domain. These 

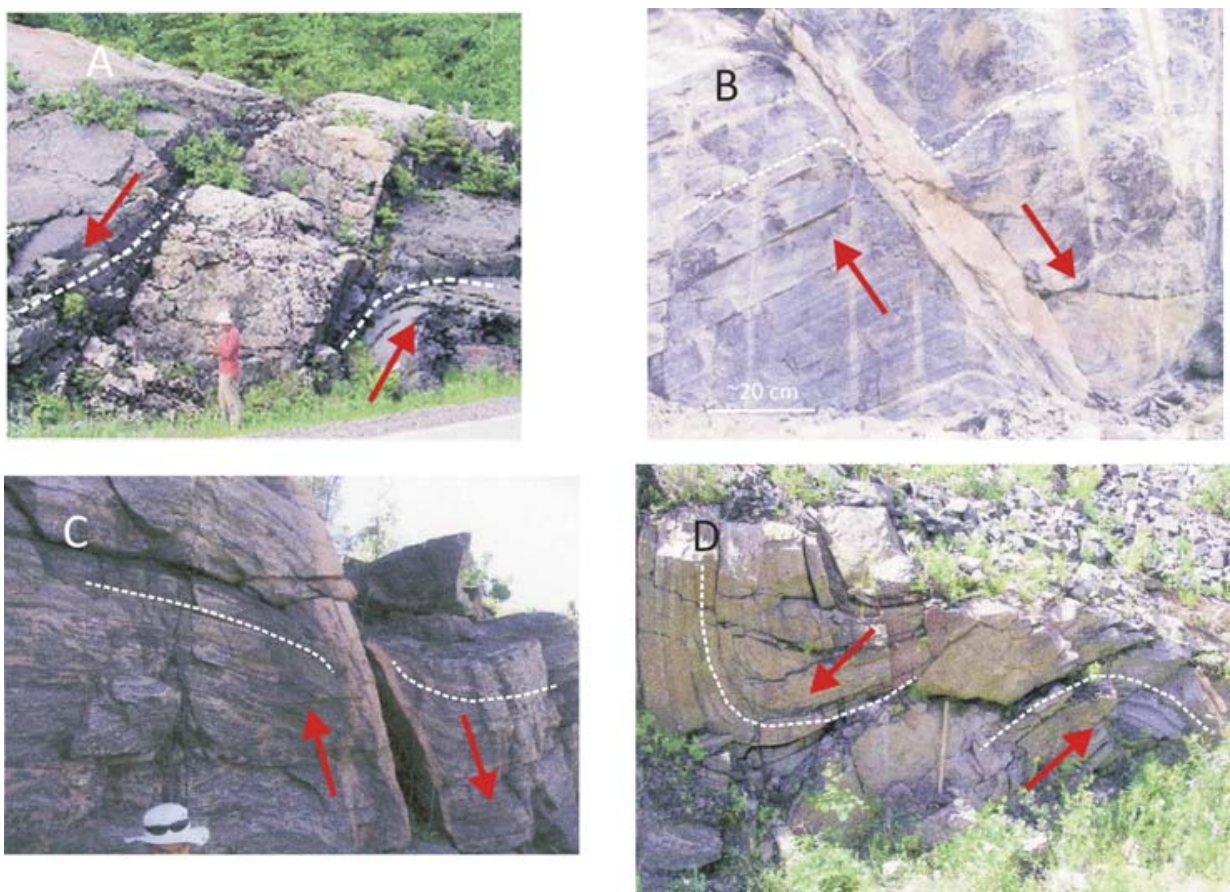

Figure 21. Set-1 SE-dipping granite pegmatite dykes emplaced in short limbs of FPFs, Muskoka domain. White dashed lines highlight curvature of gneissic lavering adjacent to dykes. Sense of displacement indicated by red arrows is top-side-down to SE. A after Schwerdtner et al. (2014), B-D after Rivers and Schwerdtner (2014).
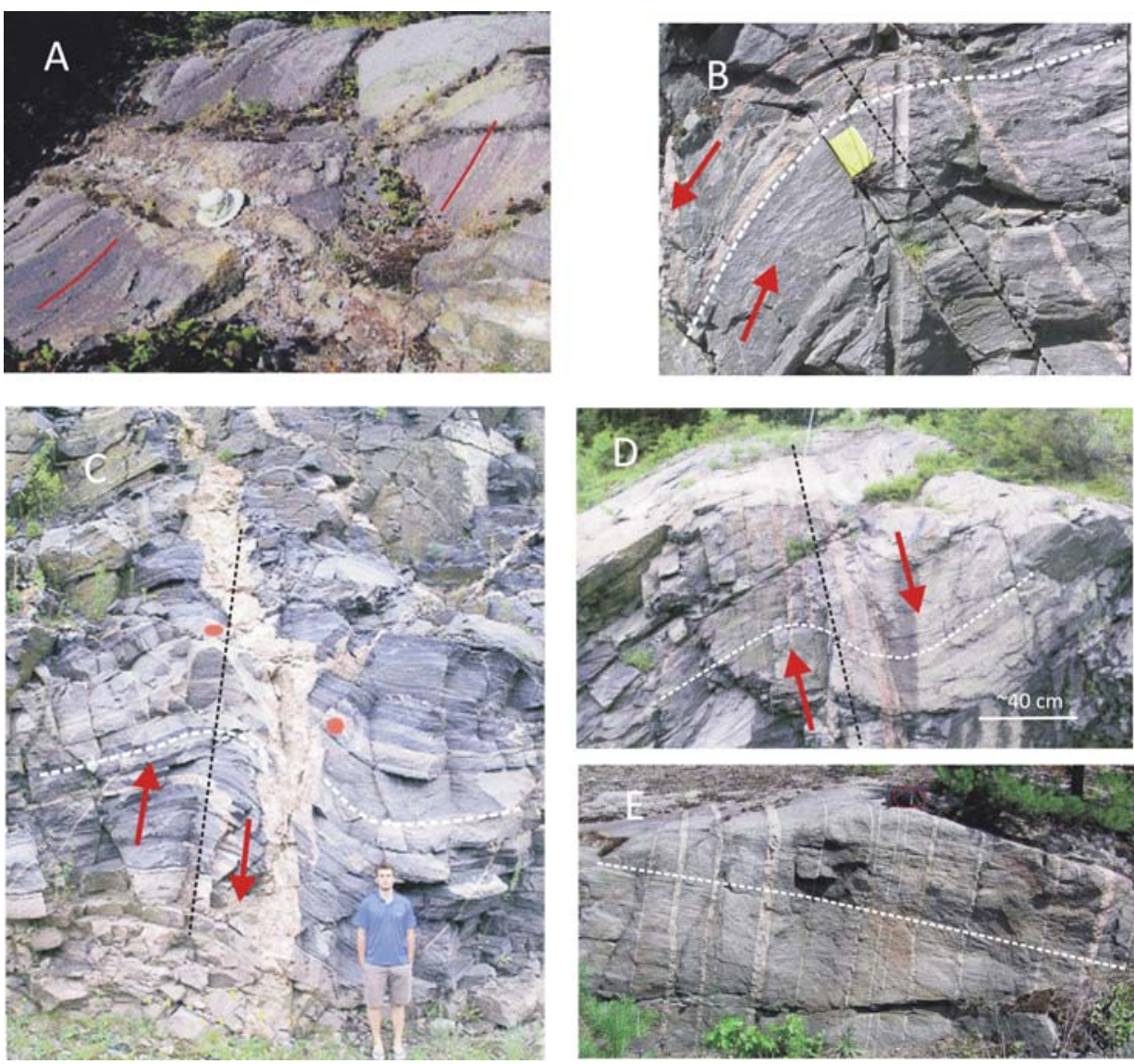

Figure 22. Set-2 granite pegmatite dykes (gneissic foliation highlighted by dashed white lines, axial surface of FPF indicated by dashed black lines; red arrows indicate sense of displacement in FPF, red dots in $\mathrm{C}$ are piercing points). A-D: Cross-cutting dykes parallel to steeply NW-dipping axial surfaces of FPFs (except $C$ in which axial surface and dyke are subvertical), Muskoka domain; in A, outcrop surface exposes short monoclinal limb of FPF with down-dip lineation (highlighted by red lines) cut by pegmatite dyke (under hat). E: swarm of subvertical dykes, Algonquin domain (camera case outlined in red for scale). Displacement in FPFs is top-side-down to SE in A-B and to NW in D. A and C modified from Schwerdtner et al. 2014. data also define a statistically significant maximum in the SE quadrant of the stereonet.

A model for emplacement of the SEdipping set-1 dykes that form a small part of the population is shown schematically in Figure 24C. For the NW-dipping set-2 dykes, we follow the interpretation of Schwerdtner et al. (2014) in part, but also propose an additional controlling factor. On the basis of the observation that the regional SE dip of the gneissic layering is statistically perpendicular to the orientations of most set- 2 dykes, Schwerdtner et al. (2014) proposed that gravitationally driven slip on incompetent layers in the mechanically active layering caused reorientation of the local principal stress from vertical to orthogonal to the layering, promoting fractures (tension gashes) in adjacent more competent layers (Fig. 24D). As with the set-1 dykes, magmatic overpressure at depth led to utilization of these fractures for emplacement of the set-2 dykes. Our new insight is that some of the set-2 dykes are preferentially oriented parallel to the axial surfaces of the FPFs (Figs. 19A, 22). These surfaces are also at high angles to the gneissic layering rendering them statistically indistinguishable to foliation normals. We speculate that the quasichevron style of the FPFs induced mechanical weakness parallel to the axial surfaces that was subsequently exploited by overpressured magma from depth.

\section{DISCUSSION}

In the previous paragraphs, we have presented observations pertaining to the postpeak structural and metamorphic development of the Muskoka domain in the study area. Based on our investigations elsewhere we have no reason to believe they are not representative of the domain as a whole, and in this section we draw them together, emphasizing salient points and noting any departures from previous interpretations.

\section{Fluid-fluxed Partial Melting and Post- peak Retrogression}

As discussed above, our work suggests the amphibolite-facies assemblages that characterize much of the Muskoka domain are a retrograde feature. The local preservation of Ottawan ( $1085 \mathrm{Ma})$ granulite- or $\mathrm{HP}$-granulite-facies assemblages provides insight into the peak Ottawan $P-T$ metamorphic conditions and suggests they were comparable to those in the underly- 


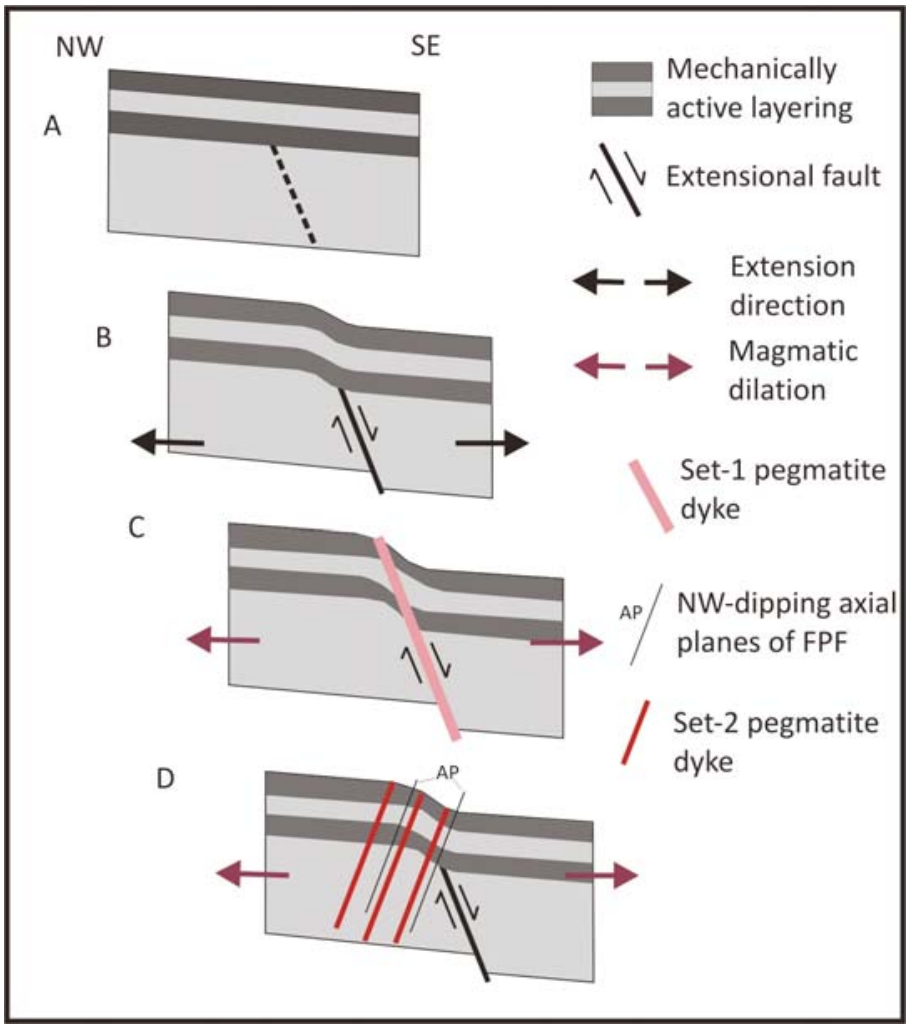

Figure 23. Sketches illustrating relationships of granite pegmatite dykes to extensional FPFs in the ORGC. Regional mechanically active gneissic layering dips gently SE. A-B: Local thinning associated with propagation of high-level extensional fault and formation of FPF. C: Emplacement of set-1 pegmatite dyke, magmatic dilation perpendicular to short limb of FPF. Subsequent displacement on fault, if any, results in brittle deformation of the dyke. D: Emplacement of set-2 dykes parallel to NW-dipping axial surface of FPF. Modified from Schwerdtner et al. (2014).

ing Algonquin domain before retrogression. Thus we deduce that the reported examples of coexisting granulite and amphibolite in the Muskoka domain resulting from local variations in $a_{\mathrm{H} 2 \mathrm{O}}$ in a $\mathrm{H}_{2} \mathrm{O}-\mathrm{CO}_{2}$ fluid phase (Pattison 1991; Timmermann et al. 2002) are relict features that elsewhere have been so pervasively overprinted by high-strain amphibolite-facies assemblages and fabrics as to be completely or almost completely obliterated. This interpretation is reinforced by the striking visual correlation between the weak strain in the preserved granulite-facies assemblages (Fig. 16A-B, D; Pattison 1991, his figs. 3-4; Timmermann et al. 2002, their fig. 3) and the highstrain amphibolite-facies assemblages that characterize most of the Muskoka domain (Fig. 7) and are especially well developed along its basal contact with the Rosseau subdomain (Rivers and Schwerdtner 2014). Thus in a regional context, we consider the evidence supports a sequential evolution involving partial to almost total retrogression of a peak granulite-facies domain.

A principal conclusion of the study of migmatization in the Muskoka domain by Slagstad et al. (2005) was that although some $O p x$-bearing leucosome was formed by Btdehydration melting on the prograde metamorphic path, the large volume of Hbl-bearing leucosome $(\geq 30-50 \%$ in many outcrops) is incompatible with both the thin melanosomes and an origin by dehydration melting, and requires that much melt was derived elsewhere by water-fluxed melting and injected into the domain. Thus both the mineralogical composition and
A.

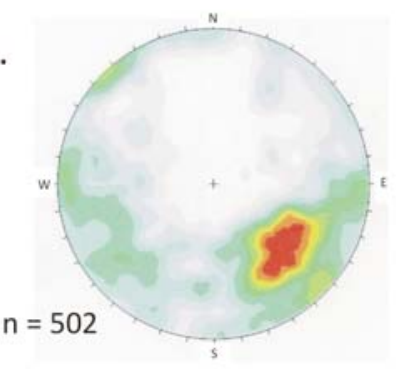

Maximum density $=3.93 \%$ per $1 \%$ area (2013 data)

Lower hemisphere equal angle projectio

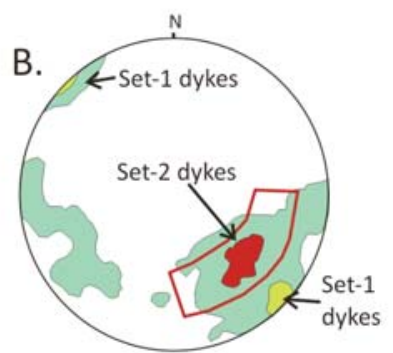

Dip lines of foliation

Maximum for poles to margins of all granite pegmatite dykes

\section{Gravitational collapse: View towards NE}

\section{Formation of set-1 dykes in FPFs}

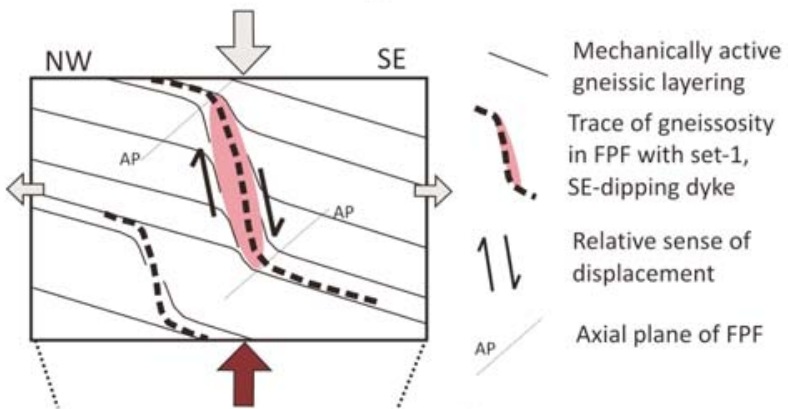

D. Formation of set-2 dykes // to axial surfaces
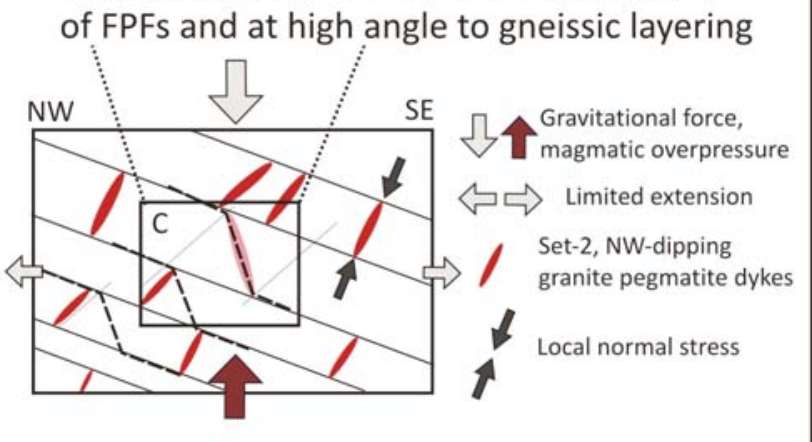

Figure 24. A: Stereographic plot of poles to margins of pegmatite dykes, Muskoka domain (2013 data). Maximum point density of 3.93\% per 1\% area is statistically significant. B: Summary of data in A showing the maximum point density within the arc segment defined by the dip directions of the host gneissic layering. $\mathrm{C}-\mathrm{D}$ : Schematic cross-sectional model of the Muskoka domain viewed towards NE showing formation of set- 1 and set- 2 dykes. Intrusion of dykes is driven by a negative vertical gradient in magmatic overpressure in crust undergoing gravitational collapse, implying emplacement in an overall regime of subhorizontal crustal extension; magma plumbing system not shown. Model is scale invariant; measured dyke widths range from a few $\mathrm{cm}$ to $15 \mathrm{~m}$ and dyke lengths are generally greater than the height of outcrops, but are otherwise unconstrained. D modified from Schwerdtner et al. (2014).

the volume of the most abundant leucosomes indicate opensystem conditions at or after the metamorphic peak.

The inference of widespread retrogression from peak granulite- to post-peak amphibolite-facies assemblages at suprasolidus conditions implies pervasive ingress of hydrous fluid at high $P-T$, and the presence of $P l$ aggregates pseudomorphing former Grs-rich Grt implies significant decompres- 
sion at high $T$. Details of the $P-T-a_{\mathrm{H} 2 \mathrm{O}}$ retrograde path at high $T$ remain poorly constrained, particularly the extent to which ingress of the hydrous fluid $( \pm \mathrm{K}-\mathrm{Na}$ brine) fluxed suprasolidus partial melting, a process that appears likely in principle. The striking correlation between postpeak strain and retrogression in the Muskoka domain suggests these variables were intimately linked and constituted a positive feedback loop, giving rise to the characteristic straight gneiss fabric (Fig. 7) with a few 'islands' of weakly strained, largely unretrogressed granulite remaining. Concerning the timing of retrogression in the ORGC, available geochronological data indicate it may have begun as early as $\sim 1060 \mathrm{Ma}$ (Bussy et al. 1995; Timmermann et al. 1997, 2002; Slagstad et al. 2004a, b), and that it was widespread and pervasive at $\sim 1020 \mathrm{Ma}$ (Ketchum et al. 1998). Moreover, brittle-ductile extension and pegmatite emplacement were ongoing in the cooled exhumed rocks at $\sim 1000 \mathrm{Ma}$ (see Schwerdtner et al. 2014). However, geochronological data that are well constrained by field relations relevant to this issue remain few and there is scope for additional work to bracket the different stages of this process more tightly.

Figure 25 is a schematic $P-T-a_{\mathrm{H} 2 \mathrm{O}}-t$ loop for the Muskoka domain. Details supporting the $\sim 100$ m.y. duration of the complete $P-T-t$ path, and the $\sim 60$ m.y. duration of the post-peak segment involving retrogression and decompression are summarized above and in the caption. The inferred central role of an influx of hydrous fluid in stage 2, driving retrogression and possibly also partial melting in the peak suprasolidus granulite-facies assemblages, is shown by the important increase in the $a_{\mathrm{H} 2 \mathrm{O}}$ variable at high $P-T$. Decompression (stage 3 ) principally took place under suprasolidus amphibolite-facies conditions and occurred while the rocks were undergoing extension, as witnessed by the attenuated high-strain amphibolite-facies foliation around boudins and pinch-and-swell structures, and the prolate $\mathrm{Pl}$ aggregates after $\mathrm{Grt}$ in mafic rocks. Transition to subsolidus conditions (stage 4) appears to have taken place after most penetrative strain had ceased but the $T$ was still sufficiently high to anneal fabrics in straight gneiss.

The nature of the dominant melting reaction (dehydration melting versus water-fluxed melting) is important as it bears on the overall density of the system and whether there was a positive contribution to buoyancy and exhumation (Clemens and Droop 1998; Teyssier and Whitney 2002; Whitney et al. 2013; Yakymchuk and Brown 2014; Weinberg and Hasalová 2015). We have followed the logic of Slagstad et al. (2005) to argue from the abundance of leucosome with peritectic $\mathrm{Hbl}$ that water-fluxed melting was widespread in the Muskoka domain, thereby supporting the thesis of Weinberg and Hasalová (2015) that this can be an important process in the deep crust.
Such leucosomes with high $a_{H 2 O}$ are unable to rise far in the crust before reaching their solidi and do not make a positive contribution to buoyancy. Thus, unless post-peak intrusion of voluminous low $a_{\mathrm{H} 2 \mathrm{O}}$ melt derived by dehydration melting in the deeper crust (i.e. Algonquin domain) was important, the ORGC as a whole would not have had positive buoyancy relative to the overlying carapace. As noted, rare occurrences of leucosome with peritectic $O p x$ in post-peak extensional structures may be explained by drainage of liquid formed by $B t$ dehydration melting on the prograde path rather than by melt formed during decompression, but their small volume suggests they would have made a negligible contribution to crustal density. Overall, these considerations lead us to conclude that exhumation of the metamorphic core of the ORGC was probably driven by regional forces rather than local buoyancy forces, i.e. it is not a gneiss dome.

\section{Collapsed Large Hot Orogen}

As noted in the introduction, following numerical modelling of LHOs by Beaumont et al. (2001), the channel flow concept was applied with some success to the hinterland of the Grenville Province (e.g. Jamieson et al. 2007, 2010; Rivers 2008, 2012; Jamieson and Beaumont 2011; Rivers et al. 2012). In this study we do not directly address the question of whether the ORGC carries a cryptic signal of channel flow at 
peak metamorphic conditions, but rather focus on the postpeak history and its bearing on gravitationally driven collapse. Figure 25 shows our interpretation that post-peak retrogression and extension in the Muskoka domain began at high $P-T$ in ductile suprasolidus rocks and continued to lower $P-T$ in brittle-ductile subsolidus rocks, resulting in profound, but spatially heterogeneous, structural reworking, i.e. compatible with the Collapsed LHO paradigm discussed in the introduction. The presence of abundant leucosome, both derived in situ and injected from elsewhere, followed by pervasive retrogression \pm fluid-present partial melting, transformed the Muskoka domain into a weak ductile detachment zone between two stronger crustal members: the underlying granulite-facies Algonquin domain, and the overlying greenschist- to amphibolite-facies Composite Arc Belt. Thus, although possibly focussed in rocks that were already weak due to grain-size reduction and the presence of leucosome at the metamorphic peak, we argue that the domain remained rheologically weak during much of its post-peak retrograde evolution.

In addition to linked dynamic retrogression and extensional strain within the Muskoka domain, Rivers and Schwerdtner (2014) reported field evidence from the vicinity of its lower contact with the granulite-facies Rosseau subdomain for dynamic downward encroachment of the domain boundary into its footwall by high-strain reworking and retrogression, a deduction that may explain the different locations of the boundary on regional maps (e.g. in Figs. 1 and 2). Moreover, there is also evidence for upward dynamic growth of the Muskoka domain into its hanging wall, for example where the northwest terminus of the Moon River lobe of the Muskoka domain is overlain by the Parry Sound domain. In this area, a monzogranite gneiss unit with 'angen structure and relict igneous texture' in the hanging wall (Parry Sound domain) was pervasively reworked in the contact zone into [monzonitic gneiss with] laminated structure and [amphibolite-facies] metamorphic fabric' in the footwall (Moon River subdomain) (descriptions from map legend, Lumbers and Vertolli 2000c). These observations imply that the high-strain amphibolite-facies character of the Muskoka domain (structural level 3) was not only progressively imposed throughout the domain itself, leaving a few remnant 'islands' of granulite-facies rocks, but also encroached into both its lower and upper contacts (structural levels 2 and 4). More generally it points to dynamic growth of high-strain extensional/ transtensional fabrics during retrogression, and incidentally suggests that not all lithologies in the Muskoka domain are monocyclic.

On the basis of seismic data (White et al. 2000), the present true thickness of the thrust stack comprising the allochthonous part of the ORGC (structural levels 2-4) is about $30 \mathrm{~km}$, and that of the Muskoka domain (structural level 3) about $7 \mathrm{~km}$ (Fig. 2). We deduce that the thickness of gneiss comprising the Muskoka domain was substantially greater prior to collapse, and thus that it records an important, but regionally unquantified component of sub-vertical thinning and sub-horizontal extensional strain. As discussed, this strain was likely strongly heterogeneous, but on the basis of visually estimated 2-D shapes of plagioclase pseudomorphs after garnet in metagabbro and mafic gneiss of $\sim 2: 1$ to $4: 1$ on horizontal surfaces (Fig. 6) and $\sim 2: 1$ to $3: 1$ on vertical surfaces, it may have been on the order of $50-75 \%$ locally, and was $\sim 90 \%$ at the base of the Muskoka domain adjacent to the contact with the boudinaged Rosseau subdomain (Fig. 17).

In summary, we consider the evidence marshalled above provides strong support for the Collapsed LHO paradigm. Moreover, since LHOs in the numerical models of Beaumont et al. (2001) are characterized by a mid-crustal channel under the orogenic plateau, this conclusion indirectly implies the former existence of a mid-crustal channel - which as noted in the introduction is compatible with the contrasting tectonic evolutions of contemporary units in the orogenic infrastructure and superstructure (Fig. 4). We thus tentatively conclude that collapse may have been focussed in the former mid-crustal channel, thereby explaining why the latter is not readily identified from the present map pattern.

\section{Metamorphic Core Complex}

Collectively these observations and deductions support a metamorphic core complex model for the present architecture of the ORGC (Fig. 26A), with the Muskoka domain forming the detachment zone separating the core from the cover. However, the ORGC is at least an order of magnitude larger in horizontal dimensions than envisaged by Whitney et al. (2013) in their review, a difference that may perhaps be explained by the large area of double thickness crust, the deep erosional level, and the unusually large amount of leucosome in the mid crust in the Grenville Orogen. Moreover, unlike the generic models of core complexes that have symmetrical dome shapes, the ORGC exhibits regional dips towards the SE and is asymmetrical, a feature we attribute to later crustal thickening of its northwestern footwall during formation of the Parautochthonous Belt in the Rigolet phase of the Grenvillian Orogeny. This asymmetry also explains why the detachment zone of the core complex is principally located along its southeastern margin.

Figure 26B emphasizes the relationship between the core and the detachment zone. In Cordilleran core complexes, the detachments range from thin $(<100 \mathrm{~m})$ zones of greenschistfacies mylonite in high-level examples (e.g. Malavieille 1993), to much thicker $(\sim 2 \mathrm{~km})$ zones of high-strain amphibolite-facies gneiss in deeper examples (e.g. Carr et al. 1987; Schaubs et al. 2002). In both cases, the rocks comprising the detachment zone were derived from the fluid-weakened top of the metamorphic core. In the case of the ORGC, although the detachment zone comprising the Muskoka domain is considerably thicker again $(\sim 7 \mathrm{~km})$, the model remains applicable in that it was similarly derived from the metamorphic core, which we deduce in this case was weakened by both fluid infiltration driving retrogression and an abundance of leucosome. Figure 26B also illustrates the tectonic context of the foliation megaboudins within the detachment zone in which 'islands' of low-strain granulite-facies relicts are surrounded by high-strain amphibolite-facies gneiss.

We have shown that the Muskoka domain is replete with evidence of boudinage on a range of scales, consistent with our interpretation that much of the preserved structure within the domain developed under conditions of far-field extension or transtension. Boudinage is inevitable in rheologically heterogeneous material undergoing significant extension, and Figure 26C illustrates the deduction that it also occurred on a crustal scale during orogenic collapse, leading to the more 


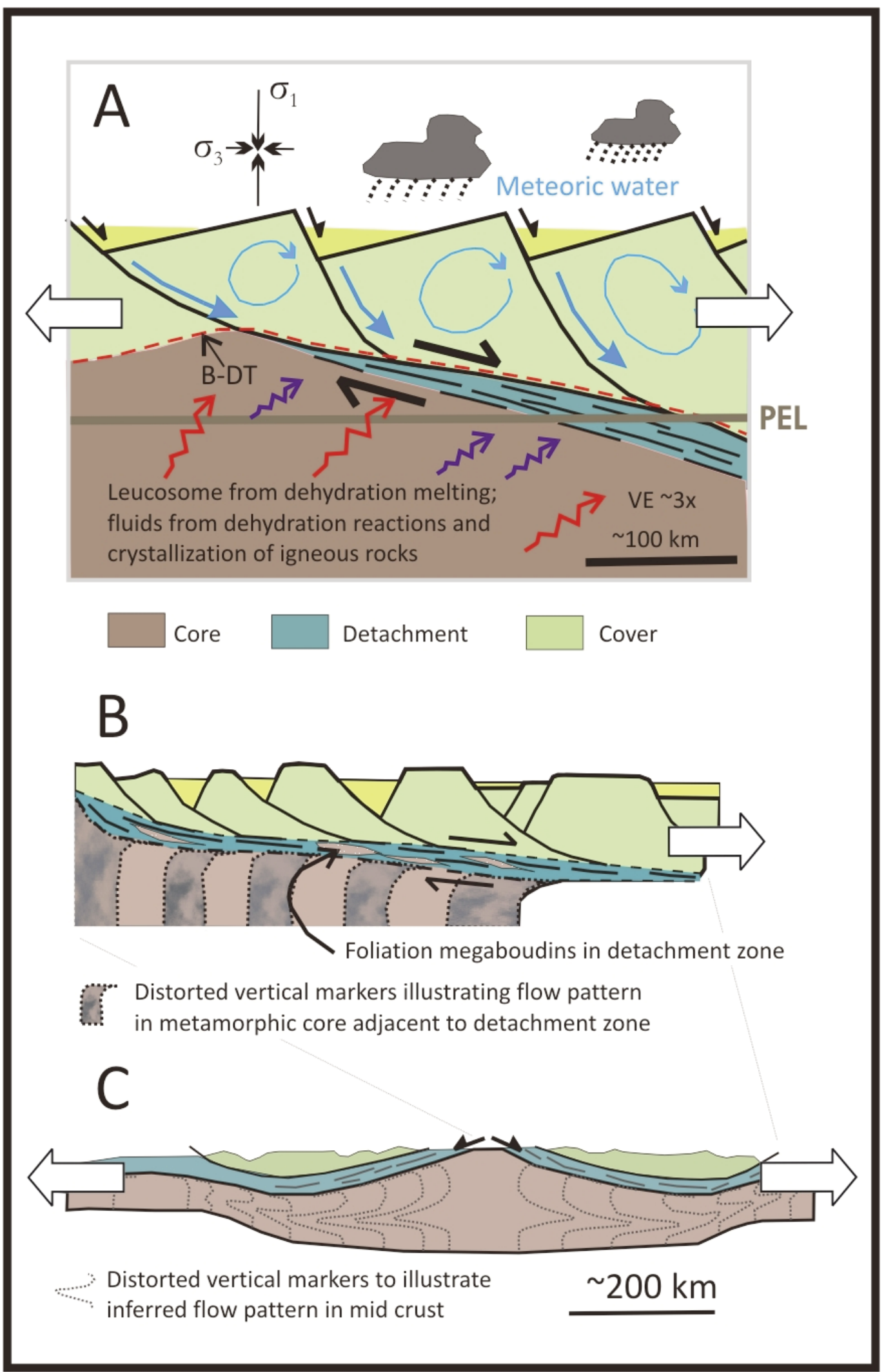

Figure 26. A: Sketch illustrating a metamorphic core complex in thickened crust with maximum far-field compression $\left(\sigma_{1}\right)$ vertical. The extensional detachment zone separates the hot ductile core from the cool, brittle-ductile cover. Applied to the Ottawa River Gneiss Complex (ORGC) at the present erosion level (PEL) the core, detachment horizon and cover are the Algonquin domain, Muskoka domain, and Composite Arc Belt respectively. Downward flow of meteoric fluids and upward flow of igneous/metamorphic fluids \pm melt results in retrogression and reaction weakening, lowering viscosity and focussing extensional strain in the detachment zone. B-DT -Brittle-ductile transition. B: Sketch illustrating the variable reworking and reorientation of gneissosity in the core adjacent to and within the detachment zone. Lozenges of high-grade core with relict structure and metamorphism surrounded by penetratively reworked and retrogressed rocks are represented by foliation megaboudins in the Muskoka domain of the ORGC. C: Regional setting of a crustal-scale core complex in a collapsed large hot orogen, showing megaboudinage of the cover and flow of the core into the neck region between megaboudins of cover rocks. A modified from Whitney et al. (2013), B modified from Malavieille (1993), C modified from Rey et al. ( 2001), Rivers (2012). 
competent cool upper crust forming megaboudins and flow of the hot ductile mid crust into the megaboudin neck regions (Rey et al. 2001; Rivers 2012).

The origin of the fluid that fluxed post-peak retrogression \pm partial melting in the Muskoka domain has not been determined. In their review Whitney et al. (2013) discussed both high-level metamorphic core complexes in which meteoric fluids were dominant and deeper-level examples, where crustal fluids were derived from metamorphic dehydration reactions and/or crystallizing igneous intrusions at depth (see Fig. 26A). In the amphibolite-facies Omineca Belt of the North American Cordillera, where this issue has been extensively evaluated, the consensus is that fluids of deep-crustal origin were dominant (e.g. Carr et al. 1987; Hinchey et al. 2006; Mulch et al. 2006; Holk and Taylor 2007; Gordon et al. 2008, 2009). Weinberg and Hasalová (2015) have pointed out that the ultimate source of crustal fluids in such deep settings may be the hydrous minerals and intergranular water in buried supracrustal rocks in the thickened orogenic crust, which is gradually released during prograde metamorphism.

As noted in the introduction, Whitney et al. (2013) stated that one of the criteria for a metamorphic core complex was that the detachment zone was the site of "...10s of kilometers of normal-sense displacement in response to lithospheric extension...". Although we have little doubt that the Muskoka domain was indeed the site of normal-sense displacement of at least this magnitude, we are unable to provide robust quantitative constraints. Malavieille (1993) illustrated a numerical kinematic model with a combination of non-uniform vertical thinning (flattening) and extensional shear at the top of the metamorphic core that may be relevant (see Fig. 26B), but as noted from limited strain markers (e.g. Pl pseudomorphs after Grt), flattening strain was strongly heterogeneous in the Muskoka domain and we have no robust constraints on the magnitude of shear strain. Moreover, Malavieille's (1993) study was a 2-D treatment of strain, but given the evidence for transtensional folding, a 3-D analysis is clearly called for. Hence, although we are presently unable to quantify the magnitude of strain that took place across the detachment zone between the core and the carapace of the ORGC (i.e. within the Muskoka domain), we consider the evidence is indisputable that it was large, involved both ductile strain within the detachment zone as a whole, as well as extensional displacement along internal shear zones, and hence is qualitatively compatible with the definition of Whitney et al. (2013).

\section{Ductile Post-peak Structural Evolution - Cross-Folding and Megaboudinage}

This study has revealed important details of the post-peak structural evolution of the mid crust during exhumation and orogenic collapse. Cross-fold systems composed of gentle to close, upright to moderately inclined buckle folds with hinge lines at high angles to the orogenic front occur on a range of scales in the Muskoka domain. Moreover, they also extend into other domains of the ORGC, including the footwall of the Allochthon Boundary (Fig. 9A). The larger cross-folds and some outcrop-scale examples carry evidence for constrictional strain parallel to their hinge lines (Fig. 6D), and exhibit irregular spacing and divergence of their hinge line traces (Fig. 9A), both hallmarks of buckle folding in an extension-dominated transtensional regime. The few examples of recumbent crossfolds (Fig. 10E, F) may mark locations where the initial orientation of the gneissic layering was steep (e.g. in the hinge zones of recumbent folds formed during thrusting), or they may have developed by refolding as shown in Figure 11; additional work is necessary to distinguish between these possibilities.

Figure 27 is a schematic diagram showing the inferred post-peak transtensional setting of the Muskoka domain in the ORGC in which the major Moon River, Seguin and Wallace synformal cross-folds developed. The figure is based on a conclusion of Fossen et al. (2013) that "the direction of transtensional fold hinges, in regions of high strain, is a good indicator of the oblique divergence that generated the folds" (p. 101). Although it is not yet possible to precisely determine the orientations and magnitudes of the wrench and extensional components of transtension in a geographic reference frame, we include the figure to show our conceptual understanding of the regional post-peak, extension-dominated sinistral transtensional regime in the hope that it may stimulate further testing and refinement.

The multi-order character of the cross-folds can be gauged from a comparison of Figures 9 and 27. Regional examples, such as the Moon River, Seguin and Wallace synforms and Bracebridge antiform, imply structural level 2 and the top of structural level 3 were buckled together as a multilayer sequence, whereas the outcrop-scale cross-folds deformed gneissic multilayers within the grey gneiss unit. Although not yet satisfactorily explained by theory and modelling, it is possible multi-order folding is a characteristic of extension-dominated transtension in exhumed high-grade terranes, as it is also a feature of the Western Gneiss Region of Norway (Krabbendam and Dewey 1988). We suspect it may be related to the suppression of fold amplification in this mode of transtension.

Formation of the regional Bracebridge antiform was accompanied by extension parallel to its axis and the development of two incipient megaboudins separated by the Camel Lake extensional bending fold that collectively provide evidence for important orogen-perpendicular extension, perhaps by as much as $200 \%$ locally on the $10 \mathrm{~km}$ scale. Moreover, the arrangement implies the presence of granulite-facies crust in structural level 2 underlying amphibolite-facies crust with granulite relicts in structural level 3, a relationship we attribute to encroaching retrogression and reworking along the interface between the core and the detachment zone in a core complex setting. As with cross-folds, the evidence for large-scale boudinage is supported by similar structures at the outcrop scale, suggesting pervasive post-peak thinning of the Muskoka domain. However, due to the limited 3-D exposure of most mesoscopic boudins, the local principal directions and magnitudes of extension cannot generally be estimated with confidence.

The weakly strained core of the Germania foliation megaboudin with relict granulite-facies rocks (Figs. 15-16) incorporates the granulite-facies metagabbro bodies in southern Seguin domain described by Pattison (1991) and some of the granulite locations studied by Timmermann et al. (2002). In Figure 27, we also show the locations of the Rockaway Lake structure, another megaboudin figured by Schwerdtner et al. (2014), and an area of granulite-facies rocks in SE Muskoka domain delineated by Timmermann et al. (2002). Given the small number of detailed petrologic studies of the eastern 


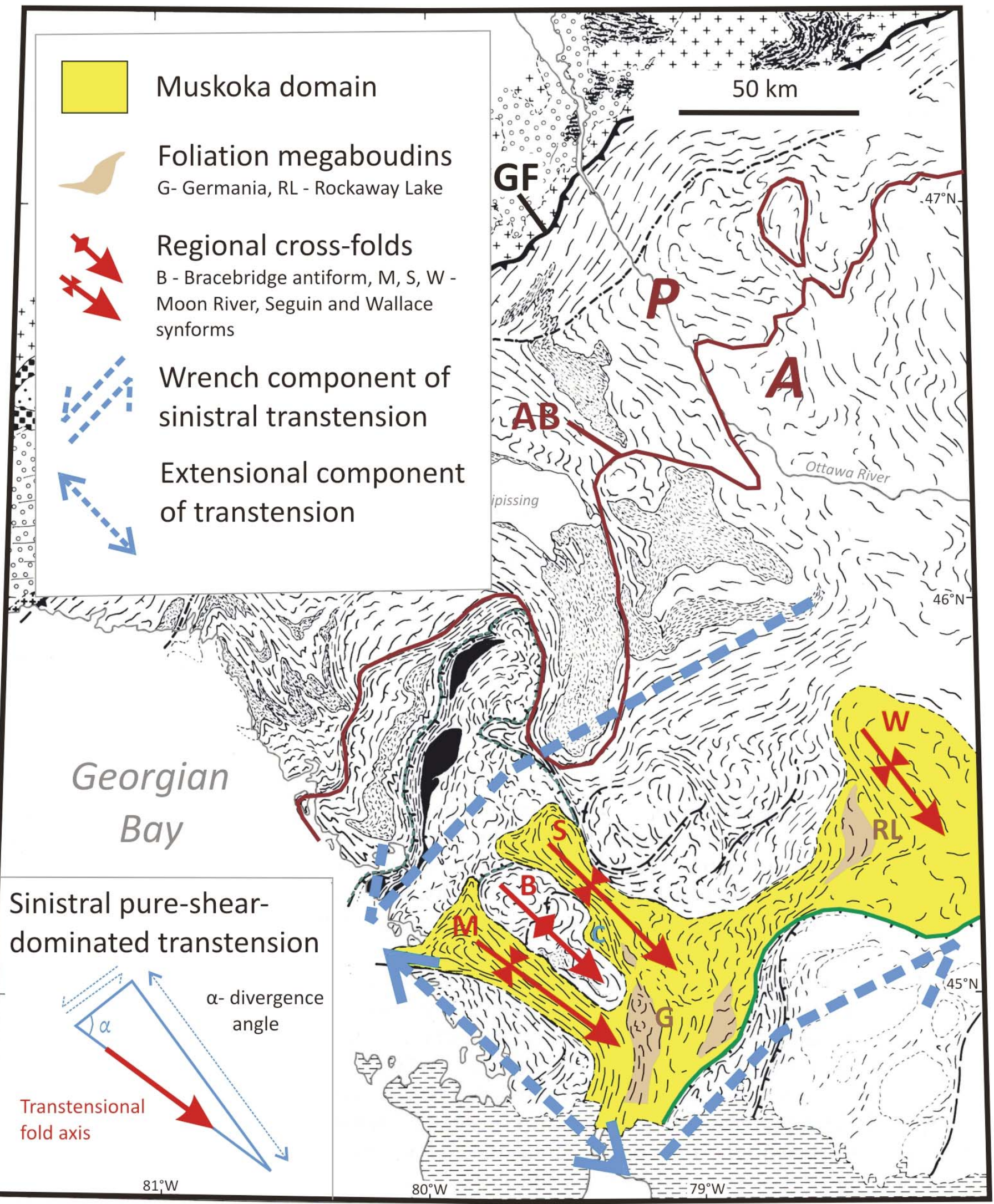

Figure 27. Sketch map of the southwestern Ottawa River Gneiss Complex (ORGC) with locations of major upright cross-folds and foliation megaboudins; B - Bracebridge antiform, M, S, W - Moon River, Seguin and Wallace synforms; G, RL - Germania and Rockaway Lake foliation megaboudins; C - Camel Lake synform (extensional bending fold). Inferred regional sinistral transtensional setting that affected the Muskoka domain and the upper part of the underlying Algonquin domain during post-peak orogenic collapse is shown by orthogonal orogen-perpendicular and orogen-parallel displacement vectors (blue arrows). Inset sketch shows the 2-D setup for extension-dominated sinistral transtension in which $20^{\circ}<\alpha<90^{\circ}$. Base map modified from Davidson (1984). A - Allochthonous, AB - Allochthon Boundary, GF - Grenville Front, P - Parautochthonous. 
Muskoka domain it is possible that other foliation megaboudins with relict granulite cores also exist.

The age ranges of cross-folding and megaboudinage in the Muskoka domain have not been precisely determined, but considering that both occurred at high temperature under suprasolidus upper amphibolite-facies conditions, they are assumed to have initiated shortly after the metamorphic peak in the early stages of exhumation and retrogression. In the specific case of the km-scale Bracebridge antiform, extension parallel to the fold hinge giving rise to megaboudinage must have begun after initiation of the transtensional folds. This leads us to tentatively deduce that both are responses to the constrictional part of the regional transtension regime.

Considering that the cross-folds in the Muskoka domain deform the attenuated amphibolite-facies fabric, and that the published age of amphibolite-facies metamorphism in the domain is $\sim 1060 \mathrm{Ma}$ (e.g. Bussy et al. 1995; Timmermann et al. 1997; 2002; Slagstad 2004a, b), cross-folds likely initiated at about this time there. However, cross-folds in the ORGC also transect the Allochthon Boundary and continue into the Parautochthonous Belt in its footwall (Fig. 9), where the age of the dominant Grenvillian metamorphism (Ottawan or Rigolet) is less well constrained (e.g. Rivers 1997, 2009; Carr et al. 2000; Rivers et al. 2012). An age range of $\sim 1070-1040 \mathrm{Ma}$ for peak metamorphism in the parautochthonous part of the ORGC is given by Carr et al. (2000), implying the cross-folds there may have formed at about the same time as those in the overlying Allochthonous Belt. This issue has implications for extensional reactivation of the Allochthon Boundary at $\sim 1020 \mathrm{Ma}$ (Ketchum et al. 1998), and for interactions between the parautochthon and the overlying allochthonous thrust stack during the later stages of the Grenvillian Orogeny that warrant further study.

\section{Brittle-Ductile Post-peak Structural Evolution - FPFs and Granite Pegmatite Dykes}

Extensional fault propagation folds (FPFs) are widespread late-stage structures in the ORGC that developed in midcrustal rocks after they had undergone substantial exhumation and cooling and they are testament to the transition to brittleductile behaviour. The short limbs of these structures are mostly $<10-15 \mathrm{~m}$ in length, but our observations are constrained by the height of the outcrops and it is possible that larger examples occur. The preferred orientation of their subhorizontal axes is approximately NE-SW, with monoclinal limbs mostly dipping SE and axial surfaces dipping steeply NW. Individual FPFs thus record evidence for limited, latestage, orogen-perpendicular extension, but they are common structures and the overall attenuation of the crust accommodated by the population as a whole is unknown.

Dilational granite pegmatite dykes intruded into the exhumed and cooled ORGC are widespread and ubiquitous, and available geochronological data indicate they crystallized at $\leq 1000 \mathrm{Ma}$. The temperature of the crust into which the pegmatite dykes were intruded is not constrained in the study area, but in the Key Harbour area in the Parautochthonous Belt (see Fig. 1), pegmatite dyke emplacement at $990 \pm 2 \mathrm{Ma}$ overlapped within uncertainties with the closure of $\mathrm{Pb}$ diffusion in titanite in the surrounding country rocks (Corrigan et al. 1994), implying a temperature of $600-650^{\circ} \mathrm{C}$ there. In the Muskoka domain, the occurrence of set-1 dykes along the short limbs of FPFs suggests they were emplaced as the latter structures developed, whereas the set- 2 dykes were emplaced subparallel to their axial surfaces after most ductile deformation in the ORGC had ceased. The presence of both dyke sets implies the underlying deeper crust in the orogenic hinterland beneath the exposed ORGC remained suprasolidus at $\leq 1000 \mathrm{Ma}$, periodically releasing small volumes of fluid-rich melt that was injected into its overlying extending brittle-ductile carapace.

\section{CONCLUSIONS}

Following formation at the top of a pile of mid-crustal granulite-facies thrust sheets, the Muskoka domain underwent pervasive post-convergent thinning, retrogression and exhumation. On the basis of evidence presented in this paper, we conclude that the dominant amphibolite-facies metamorphic assemblages, fabrics, and structures of the Muskoka domain, including its prominent regional NW-trending synformal lobes, developed to a large degree after the peak of Ottawan metamorphism, record prolonged extensional or transtensional strain over $\geq 60$ m.y., and document profound orogenic collapse. The principal result of this collapse was the juxtaposition of the underlying exhumed, hot ductile mid crust (Algonquin domain) against the overlying cool, brittle-ductile upper crust (Composite Arc Belt), the two being separated by a weak high-strain detachment zone (the Muskoka domain), collectively leading to the development of a crustal-scale metamorphic core complex partly surrounded at the present level of erosion by its lower-grade cover. Conductive heating of the base of the Composite Arc Belt by juxtaposition against the exhumed hot ORGC is predicted in this setting, but has not yet been recorded. Rheological weakening of peak granulitefacies rocks in the Muskoka domain was caused by the presence of abundant leucosome and widespread post-peak retrogression, the latter implying ingress of voluminous quantities of hydrous fluid into the suprasolidus mid crust. This weakening led to important vertical thinning and subhorizontal extension, forming what is now a $\sim 7 \mathrm{~km}$ thick detachment zone. Collectively, these features are compatible with the Collapsed LHO paradigm.

The scale of the metamorphic core complex preserved in the ORGC is substantially greater than that illustrated schematically in a recent review of core complexes by Whitney et al. (2013), and the estimated $7 \mathrm{~km}$ thickness of the detachment zone (Muskoka domain) is similarly much greater than that of other examples described in the literature (mostly $\leq 2$ $\mathrm{km})$. We attribute this 'super-sizing' to the deep level of erosion, and to the large area of double thickness crust at the Ottawan metamorphic peak, the abundance of leucosome, and the inferred voluminous influx of melt and hydrous fluid after the metamorphic peak. Similarly, the estimated duration of extensional collapse of the Grenville Orogen $(\geq 60$ m.y.) is substantially longer than that determined for Phanerozoic examples (mostly $<20$ m.y.).

Additional work is necessary to assess the implications of the Collapsed LHO paradigm for the tectonic interpretation of the ORGC as a whole, especially with respect to the proposed correlation within structural level 3 of the Muskoka domain in the southeast ORGC with the Shawanaga and Ahmic domains farther northwest (Fig. 2; Jamieson et al. 2007; Jamieson and 
Beaumont 2011), and also to investigate possible continuation of the Muskoka domain / structural level 3 eastward into eastern Quebec. Recent work in central Quebec has concluded that the granulite-facies Mékinak domain and its amphibolitefacies structural cover, known as the Shawinigan domain, also comprise a metamorphic core complex (Soucy La Roche et al. 2015), supporting the contention that these structures are widespread in the Grenville Province (Rivers 2012). However, in that case the detachment zone comprises a system of anastomosing shear zones in which deformation was subsolidus, and the collapse process lasted a maximum of $35 \mathrm{~m}$.y. These differences suggest that Grenvillian metamorphic core complexes were initiated at different times, were operative under different $P-T$ conditions, and probably record different amounts of extensional strain.

\section{ACKNOWLEDGEMENTS}

This paper is an outgrowth of the introduction to the field guide for the 2014 Friends of the Grenville (FOG) field trip, which focussed on the geology of the Muskoka domain around Gravenhurst, Ontario (Rivers and Schwerdtner 2014). Both papers are attempts to integrate field observations in the Ontario segment of the Ottawa River Gneiss Complex, perhaps the best exposed and most intensively studied high-grade gneiss terrane in the Grenville Province, with published geophysical, structural and petrologic data, recent theoretical models of folding and faulting in extensional and transtensional systems, and numerical models of the orogenic collapse process. Important insight was gained by working across a range of scales, made possible by decades of observations and compilations by others. As such, our results owe a debt to the many who came before. We are delighted to submit the paper to the series honouring the contributions of Andrew Hynes, whose rigorous approach and insight into tectonic processes and ability to synthesize information from a range of scales we greatly admire. We hope it meets his high standards and that the ideas and concepts are tested and refined in other high-grade gneiss terranes in the Grenville Province and elsewhere. We thank Félix Gervais and Chris Yakymchuk for critical and perceptive journal reviews that challenged us to sharpen our arguments about crustal melting and migmatites, and the journal staff for meticulous editorial work. The research was partly supported by NSERC Discovery Grants to the first author.

\section{REFERENCES}

Anovitz, L.M., and Essene, E.J., 1990, Thermobarometry and pressure-temperature paths in the Grenville Province of Ontario: Journal of Petrology, v. 31, p. 197-241, http://dx.doi.org/10.1093/petrology/31.1.197.

Aranovich, L.Y., Newton, R.C., and Manning, C.E., 2013, Brine-assisted anatexis Experimental melting in the system haplogranite- $\mathrm{H}_{2} \mathrm{O}-\mathrm{NaCl}-\mathrm{KCl}$ at deepcrustal conditions: Earth and Planetary Science Letters, v. 374, p. 111-120, http://dx.doi.org/10.1016/j.epsl.2013.05.027.

Beaumont, C., Jamieson, R.A., Nguyen, M.H., and Lee, B., 2001, Mid-crustal channel flow in large hot orogens: Results from coupled thermal-mechanical models, in Slave-Northern Cordillera Lithospheric Evolution (SNORCLE) and Cordilleran Tectonics Workshop: Lithoprobe Secretariat, UBC, Vancouver, BC, Lithoprobe Report 79, p. 112-170.

Beaumont, C., Nguyen, M.H., Jamieson, R.A., and Ellis, S., 2006, Crustal flow modes in large hot orogens, in Law, R.D., Searle, M.P., and Godin, L., eds., Channel Flow, Ductile Extrusion and Exhumation in Continental Collision Zones Geological Society, London, Special Publications, v. 268, p. 91-145, http://dx.doi.org/10.1144/gsl.sp.2006.268.01.05.

Berman, R.G., 1991, Thermobarometry using multi-equilibrium calculations: a new technique with petrological applications: Canadian Mineralogist, v. 29, p. 833-855.

Brown, M., 2013, Granite: From genesis to emplacement: Geological Society of America Bulletin, v. 125, p. 1079-1113, http://dx.doi.org/10.1130/B30877.1.

Busch, J.P., and van der Pluijm, B.A., 1996, Late orogenic, plastic to brittle extension along the Robertson Lake shear zone: implications for the style of deep-crustal extension in the Grenville orogen, Canada: Precambrian Research, v. 77, p. 41-57, http://dx.doi.org/10.1016/0301-9268(95)00044-5

Busch, J.P., van der Pluijm, B.A., Hall, C.M., and Essene, E.J., 1996a, Listric normal faulting during postorogenic extension revealed by ${ }^{40} \mathrm{Ar} /{ }^{39} \mathrm{Ar}$ thermochronology near the Robertson Lake shear zone, Grenville orogen, Canada: Tectonics, v. 15, p. 387-402, http://dx.doi.org/10.1029/95TC03501.

Busch, J.P., Essene, E.J., and van der Pluijm, B.A., 1996b, Evolution of deep-crustal normal faults: Constraints from thermobarometry in the Grenville orogen,
Ontario, Canada: Tectonophysics, v. 265, p. 83-100, http://dx.doi.org/ 10.1016/S0040-1951(96)00147-3.

Busch, J.P., Mezger, K., and van der Pluijm, B.A., 1997, Suturing and extensional reactivation in the Grenville orogen, Canada: Geology, v. 25, p. 507-510, http://dx.doi.org/10.1130/0091-7613(1997)025<0507:SAERIT>2.3.CO;2

Bussy, F., Krogh, T.E., Klemens, W.P., and Schwerdtner, W.M., 1995, Tectonic and metamorphic events in the westernmost Grenville Province, central Ontario: new results from high-precision $\mathrm{U}-\mathrm{Pb}$ zircon geochronology: Canadian Journal of Earth Sciences, v. 32, p. 660-671, http://dx.doi.org/10.1139/e95-055.

Carr, S.D., Parrish, R.R., and Brown, R.L., 1987, Eocene structural development of the Valhalla complex, southeastern British Columbia: Tectonics, v. 6, p 175-196, http://dx.doi.org/10.1029/TC006i002p00175.

Carr, S.D., Easton, R.M., Jamieson, R.A., and Culshaw, N.G., 2000, Geologic transect across the Grenville orogen of Ontario and New York: Canadian Journal of Earth Sciences, v. 37, p. 193-216, http://dx.doi.org/10.1139/e99-074.

Clemens, J.D., and Droop, G.T.R., 1998, Fluids, $P-T$ paths and the fates of anatectic melts in the Earth's crust: Lithos, v. 44, p. 21-36, http://dx.doi.org/ 10.1016/S0024-4937(98)00020-6.

Coney, P.J., 1974, Structural analysis of the Snake Range 'Décollement,' east-central Nevada: Geological Society of America Bulletin, v. 85, p. 973-978, http://dx.doi.org/10.1130/0016-7606(1974)85<973:saotsr>2.0.co;2.

Coney, P.J., 1980, Cordilleran metamorphic core complexes: An overview, in Crittenden, M.D., Jr., Coney, P.J., and Davis, G.H., eds., Cordilleran Metamorphic Core Complexes: Geological Society of America Memoirs, v. 153, p. 7-31, http://dx.doi.org/10.1130/MEM153-p7.

Corrigan, D., and van Breemen, O., 1997, U-Pb constraints for the lithotectonic evolution of the Grenville Province along the Mauricie transect, Quebec: Canadian Journal of Earth Sciences, v. 34, p. 299-316, http://dx.doi.org/10.1139/ e17-027.

Corrigan, D., Culshaw, N.G., and Mortensen, J.K., 1994, Pre-Grenvillian evolution and Grenvillian overprinting of the Parautochthonous Belt in Key Harbour, Ontario: U-Pb and field constraints: Canadian Journal of Earth Sciences, v. 31, p. 583-596, http://dx.doi.org/10.1139/e94-051.

Corriveau, L., and Gorton, M.P., 1993, Co-existing K-rich alkaline and shoshonitic magmatism of arc affinities in the Proterozoic: a reassessment of syenitic rocks in the southwestern Grenville Province: Contributions to Mineralogy and Petrology, v. 113, p. 262-279, http://dx.doi.org/10.1007/BF00283233.

Corriveau, L., Heaman, L.M., Marcantonio, F., and van Breemen, O., 1990, 1.1 Ga K-rich alkaline plutonism in the SW Grenville Province, U-Pb constraints for the timing of subduction-related magmatism: Contributions to Mineralogy and Petrology, v. 105, p. 473-485, http://dx.doi.org/10.1007/BF00286834.

Cosca, M.A., Sutter, J.F., and Essene, E.J., 1991, Cooling and inferred uplift/erosion history of the Grenville orogen, Ontario: Constraints from ${ }^{40} \mathrm{Ar} /{ }^{39} \mathrm{Ar}$ thermochronology: Tectonics, v. 10, p. 959-977, http://dx.doi.org/10.1029/ 91 TC00859.

Cosca, M.A., Essene, E.J., Kunk, M.J., and Sutter, J.F., 1992, Differential unroofing within the Central Metasedimentary Belt of the Grenville Orogen: Constraints from ${ }^{40} \mathrm{Ar} /{ }^{39} \mathrm{Ar}$ thermochronology: Contributions to Mineralogy and Petrology, v. 110, p. 211-225, http://dx.doi.org/10.1007/BF00310739.

Cosca, M.A., Essene, E.J., Mezger, K., and van der Pluijm, B.A., 1995, Constraints on the duration of tectonic processes: Protracted extension and deep-crustal rotation in the Grenville orogeny: Geology, v. 23, p. 361-364, http://dx.doi.org/10.1130/0091-7613(1995)023<0361:COTDOT>2.3.CO;2.

Culshaw, N., 2005, Buckle folding and deep-crustal shearing of high-grade gneisses at the junction of two major high-strain zones, Central Gneiss Belt, Grenville Province, Ontario: Canadian Journal of Earth Sciences, v. 42, p. 1907-1925, http://dx.doi.org/10.1139/e05-078.

Culshaw, N.G., Davidson, A., and Nadeau, L., 1983, Structural subdivisions of the Grenville Province in the Parry Sound-Algonquin region, Ontario: Geological Survey of Canada, Current Research, Part B, Paper 83-1B, p. 243-252.

Culshaw, N.G., Ketchum, J.W.F., Wodicka, N., and Wallace, P., 1994, Deep crustal ductile extension following thrusting in the southwestern Grenville Province, Ontario: Canadian Journal of Earth Sciences, v. 31, p. 160-175, http://dx.doi.org/10.1139/e94-013.

Culshaw, N.G., Jamieson, R.A., Ketchum, J.W.F., Wodicka, N., Corrigan, D., and Reynolds, P.H., 1997, Transect across the northwestern Grenville orogen, Georgian Bay, Ontario: Polystage convergence and extension in the lower orogenic crust: Tectonics, v. 16, p. 966-982, http://dx.doi.org/10.1029/97TC02285.

Culshaw, N.G., Corrigan, D., Ketchum, J.W.F., Wallace, P., Wodicka, N., and Easton, R.M., 2004, Georgian Bay geological synthesis, Grenville Province: Explanatory notes for Preliminary Maps P.3548 to P.3552: Ontario Geological Survey, Open File Report 6143.

Davidson, A., 1984, Identification of ductile shear zones in the southwestern Grenville Province of the Canadian Shield, in Kröner, A., and Greiling, R., eds., Precambrian Tectonics Illustrated: E. Schweizerbart'sche Verlagsbuchhandlung, Stuttgart, p. 263-280. 
Davidson, A., 1990, Evidence for eclogite metamorphism in the southwestern Grenville Province: Geological Survey of Canada, Current Research Part C, Paper 90-1C, p. 113-118.

Davidson, A., and Morgan, W.C., 1981, Preliminary notes on the geology east of Georgian Bay, Grenville Structural Province, Ontario: Geological Survey of Canada, Paper 81-A, p. 175-190.

Davidson, A., Culshaw, N.G., and Nadeau, L., 1982, Preliminary notes on the geology east of Georgian Bay, Grenville Structural Province, Ontario: Geological Survey of Canada, Current Research Part A, Paper 81-1A, p. 291-298.

Dewey, J.F., Holdsworth, R.E., and Strachan, R.A., 1998, Transpression and transtension zones, in Holdsworth, R.E., Strachan, R.A., and Dewey, J.F., eds., Continental Transpressional and Transtensional Tectonics: Geological Society, London, Special Publications, v. 135, p. 1-14, http://dx.doi.org/10.1144/ gsl.sp.1998.135.01.01.

Dickin, A.P., and Guo, A., 2001, The location of the Allochthon Boundary Thrust and the Archean-Proterozoic suture in the Mattawa area of the Grenville Province: Nd isotopic evidence: Precambrian Research, v. 107, p. 31-43, http://dx.doi.org/10.1016/S0301-9268(00)00153-4

Dickin, A.P., and McNutt, R.H., 1990, Nd model-age mapping of Grenville lithotectonic domains: mid-Proterozoic crustal evolution in Ontario, in Gower, C.F., Rivers, T., and Ryan, A.B., eds., Mid-Proterozoic Laurentia-Baltica: Geological Association of Canada Special Paper 38, p. 79-94.

Dickin, A.P., Moretton, K., and North, R., 2008, Isotopic mapping of the Allochthon Boundary Thrust in the Grenville Province of Ontario, Canada: Precambrian Research, v. 167, p. 260-266, http://dx.doi.org/10.1016/j.precamres.2008.08.007.

Dickin, A.P., Herrell, M., Moore, E., Cooper, D., and Pearson, S., 2014, Nd isotope mapping of allochthonous Grenvillian klippen: Evidence for widespread 'rampflat' thrust geometry in the SW Grenville Province: Precambrian Research, v. 246, p. 268-280, http://dx.doi.org/10.1016/j.precamres.2014.03.012.

Docka, R.K., Ross, T.M., and Lu, G., 1998, The Trans Mojave-Sierran shear zone and its role in Early Miocene collapse of southwestern North America, in Holdsworth, R.E., Strachan, R.A., and Dewey, J.F., eds., Continental Transpressional and Transtensional Tectonics: Geological Society, London, Special Publications, v. 135, p. 183-202, http://dx.doi.org/10.1144/gsl.sp.1998.135.01.12.

Easton, R.M., 1992, The Grenville Province and the Proterozoic history of central and southern Ontario, in Thurston, P.C., Williams, H.R., Sutcliffe, R.H., and Stott, G.M., eds., Geology of Ontario: Ontario Geological Survey, Special volume 4, p. 715-904.

Ferrill, D.A., Morris, A.P., and McGinniss, R.N., 2012, Extensional fault-propagation folding in mechanically layered rocks: The case against the frictional drag mechanism: Tectonophysics, v. 576-577, p. 78-85, http://dx.doi.org/10.1016/ j.tecto.2012.05.023.

Fossen, H., Teyssier, C., and Whitney, D.L., 2013, Transtensional folding: Journal of Structural Geology, v. 56, p. 89-102, http://dx.doi.org/10.1016/ j.jsg.2013.09.004

Gordon, S.M., Whitney, D.L., Teyssier, C., Grove, M., and Dunlap, W.J., 2008, Timescales of migmatization, melt crystallization, and cooling in a Cordilleran gneiss dome: Valhalla complex, southeastern British Columbia: Tectonics, v. 27, TC4010, http://dx.doi.org/10.1029/2007TC002103.

Gordon, S.M., Grove, M., Whitney, D.L., Schmitt, A.K., and Teyssier, C., 2009, Fluid-rock interaction in orogenic crust tracked by zircon depth profiling: Geology, v. 37, p. 735-738, http://dx.doi.org/10.1130/G25597A.1.

Gower, R.J.W., 1992, Nappe emplacement direction in the Central Gneiss Belt, Grenville Province, Ontario, Canada: Evidence for oblique collision: Precambrian Research, v. 59, p. 73-94, http://dx.doi.org/10.1016/03019268(92)90052-P.

Hinchey, A.M., Carr, S.D., McNeill, P.D., and Rayner, N., 2006, Paleocene-Eocene high-grade metamorphism, anatexis, and deformation in the Thor-Odin dome, Monashee complex, southeastern British Columbia: Canadian Journal of Earth Sciences, v. 43, p. 1341-1365, http://dx.doi.org/10.1139/e06-028.

Hobbs, B.E., Means, W.D., and Williams, P.F., 1976, An Outline of Structural Geology: John Wiley and Sons, Inc., 571 p.

Holk, G.J., and Taylor, H.P., Jr., 2007, ${ }^{18} \mathrm{O} /{ }^{16} \mathrm{O}$ Evidence for contrasting hydrothermal regimes involving magmatic and meteoric-hydrothermal waters at the Valhalla metamorphic core complex, British Columbia: Economic Geology, v. 102, p. 1063-1078, http://dx.doi.org/10.2113/gsecongeo.102.6.1063.

Jamieson, R.A., and Beaumont, C., 2011, Coeval thrusting and extension during lower crustal ductile flow-implications for exhumation of high-grade metamorphic rocks: Journal of Metamorphic Geology, v. 29, p. 33-51, http://dx.doi.org/10.1111/j.1525-1314.2010.00908.x.

Jamieson, R.A., Ketchum, J.W.F., Slagstad, T., Rivers, T., and Culshaw, N.G., 2003 Omphacite and zircon in high-pressure metabasite, Shawanaga domain, western Grenville Province: the truth about some beauties (Abstract): Geological Association of Canada-Mineralogical Association of Canada Annual Meeting, v. 28 A325.
Jamieson, R.A., Beaumont, C., Nguyen, M.H., and Culshaw, N.G., 2007, Synconvergent ductile flow in variable-strength continental crust: Numerical models with application to the western Grenville orogen: Tectonics, v. 26, TC5005, http://dx.doi.org/10.1029/2006TC002036.

Jamieson, R.A., Beaumont, C., Warren, C.J., and Nguyen, M.H., 2010, The Grenville orogen explained? Applications and limitations of integrating numerical models with geological and geophysical data: Canadian Journal of Earth Sciences, v. 47, p. 517-539, http://dx.doi.org/10.1139/E09-070.

Janák, M., Plašienka, D., Frey, M., Cosca, M., Schmidt, S.TH, Lupták, B., and Méres, S., 2001, Cretaceous evolution of a metamorphic core complex, the Veporic unit, western Carpathians (Slovakia): $P-T$ conditions and in situ ${ }^{40} \mathrm{Ar} /{ }^{39} \mathrm{Ar} \mathrm{UV}$ laser probe dating of metapelites: Journal of Metamorphic Geology, v. 19, p. 197-216, http://dx.doi.org/10.1046/j.0263-4929.2000.00304.x.

Kargaranbafghi, F., and Neubauer, F., 2015, Lithospheric thinning associated with formation of a metamorphic core complex and subsequent formation of the Iranian plateau: GSA Today, v. 25, p. 4-8, http://dx.doi.org/10.1130/ GSATG229A.1.

Ketchum, J.W.F., and Davidson, A., 2000, Crustal architecture and tectonic assembly of the Central Gneiss Belt, southwestern Grenville Province, Canada: a new interpretation: Canadian Journal of Earth Sciences, v. 37, p. 217-234, http://dx.doi.org/10.1139/e98-099.

Ketchum, J.W.F., and Krogh, T.E., 1997, U-Pb constraints on high-pressure metamorphism in the Central Gneiss Belt, southwestern Grenville orogeny (Abstract): Geological Association of Canada-Mineralogical Association of Canada Annual Meeting, v. 22, A78

Ketchum, J.W.F., and Krogh, T.E., 1998, U-Pb constraints on high-pressure metamorphism in the southwestern Grenville orogeny (Abstract): Goldschmidt Conference 1998, Mineralogical Magazine, v. 62A, p. 775-776.

Ketchum, J.W.F., Heaman, L.M., Krogh, T.E., Culshaw, N.G., and Jamieson, R.A., 1998, Timing and thermal influence of late orogenic extension in the lower crust: a U-Pb geochronological study from the southwest Grenville orogen, Canada: Precambrian Research, v. 89, p. 25-45, http://dx.doi.org/10.1016/ S0301-9268(97)00079-X

Klemens, W.P., 1996, Structural analysis of the Ahmic domain and its border zones, southwestern Grenville orogen, Ontario, Canada: Unpublished PhD thesis, University of Toronto, Toronto, ON, $197 \mathrm{p}$.

Krabbendam, M., and Dewey, J.F., 1998, Exhumation of UHP rocks by transtension in the Western Gneiss Region, Scandinavian Caledonides, in Holdsworth, R.E., Strachan, R.A., and Dewey, J.F., eds., Continental Transpressional and Transtensional Tectonics: Geological Society, London, Special Publications, v. 135, p. 159-181, http://dx.doi.org/10.1144/gsl.sp.1998.135.01.11.

Kruckenberg, S.C., Vanderhaeghe, O., Ferré, E.C, Teyssier, C., and Whitney, D.L., 2011, Flow of partially molten crust and the internal dynamics of a migmatite dome: Tectonics, v. 30, TC3001, http://dx.doi.org/10.1029/2010TC002751.

Lister, G.S., and Davis, G.A., 1989, The origin of metamorphic core complexes and detachment faults formed during Tertiary continental extension in the northern Colorado region, U.S.A.: Journal of Structural Geology, v. 11, p. 65-94, http://dx.doi.org/10.1016/0191-8141(89)90036-9.

Lumbers, S.B., and Vertolli, V.M., 2000a, Precambrian geology, Bracebridge area: Ontario Geological Survey, Preliminary Map P.3412, NTS: 31E/4, scale $1: 50,000$.

Lumbers, S.B., and Vertolli, V.M., 2000b, Precambrian geology, Lake Joseph area: Ontario Geological Survey, Preliminary Map P.3411, NTS: 31E/3, scale $1: 50,000$.

Lumbers, S.B., and Vertolli, V.M., 2000c, Precambrian geology, Orrville area: Ontario Geological Survey, Preliminary Map P.3414, NTS: 31E/5, scale $1: 50,000$.

Lumbers, S.B., Vertolli, V.M., and Schwerdtner, W.M., 2000, Precambrian geology, Gravenhurst area: Ontario Geological Survey, Preliminary Map P.3409, NTS: 31D/14, scale 1:50,000.

Malavieille, J., 1993, Late orogenic extension in mountain belts: Insights from the Basin and Range and the late Paleozoic Variscan Belt: Tectonics, v. 12, p. 1115-1130, http://dx.doi.org/10.1029/93TC01129.

Malavieille, J., Guihot, P., Costa, S., Lardeaux, J.M., and Gardien, V., 1990, Collapse of the thickened Variscan crust in the French Massif Central: Mont Pilat extensional shear zone and the St. Etienne late Carboniferous basin: Tectonophysics, v. 177, p. 139-149, http://dx.doi.org/10.1016/0040-1951(90)90278-G.

Martignole, J., and Calvert, A.J., 1996, Crustal-scale shortening and extension across the Grenville Province of western Québec: Tectonics, v. 15, p. 376-386, http://dx.doi.org/10.1029/95TC03748.

Martignole, J., Calvert, A.J., Friedman, R., and Reynolds, P., 2000, Crustal evolution along a seismic section across the Grenville Province (western Quebec): Canadian Journal of Earth Sciences, v. 37, p. 291-306, http://dx.doi.org/10.1139/ e99-123.

McFadden, R.R., Teyssier, C., Siddoway, C.S., Whitney, D.L., and Fanning, C.M., 2010, Oblique dilation, melt transfer, and gneiss dome emplacement: Geology, 
v. 38, p. 375-378, http://dx.doi.org/10.1130/G30493.1.

McGregor, V.R., and Friend, C.R.L., 1997, Field recognition of rocks totally retrogressed from granulite facies: an example from Archaean rocks in the Paamiut region, South-West Greenland: Precambrian Research, v. 86, p. 59-70, http://dx.doi.org/10.1016/S0301-9268(97)00041-7.

McLelland, J.M., Selleck, B.W., and Bickford, M.E., 2013, Tectonic evolution of the Adirondack Mountains and Grenville Orogen inliers within the USA: Geoscience Canada, v. 40, p. 318-352, http://dx.doi.org/10.12789/geocanj.2013.40.022.

McMullen, S.M., 1999, Tectonic evolution of the Bark Lake area, eastern Central Gneiss Belt, Ontario Grenville: Constraints from geology, geochemistry and $\mathrm{U}-\mathrm{Pb}$ geochronology: Unpublished MSc thesis, Carleton University, Ottawa, ON, $175 \mathrm{p}$.

Mezger, K., van der Pluijm, B.A., Essene, E.J., and Halliday, A.N., 1991, Synorogenic collapse: A perspective from the middle crust, the Proterozoic Grenville orogeny: Science, v. 254, p. 695-698, http://dx.doi.org/10.1126/science.254.5032.695.

Mulch, A., Teyssier, C., Cosca, M.A., and Vennemann, T.W., 2006, Thermomechanical analysis of strain localization in a ductile detachment zone: Journal of Geophysical Research, v. 111, B12405, http://dx.doi.org/10.1029/2005JB004032.

Nadeau, L., and van Breemen, O., 1998, Plutonic ages and tectonic setting of the Algonquin and Muskoka allochthons, Central Gneiss Belt, Grenville Province, Ontario: Canadian Journal of Earth Sciences, v. 35, p. 1423-1438, http://dx.doi.org/10.1139/e98-077.

Pattison, D.R.M., 1991, Infiltration-driven dehydration and anatexis in granulite facies metagabbro, Grenville Province, Ontario, Canada: Journal of Metamorphic Geology, v. 9, p. 315-332.

Rey, P., Vanderhaegue, O., and Teyssier, C., 2001, Gravitational collapse of the continental crust: definition, regimes and modes: Tectonophysics, v. 342, p. 435-449, http://dx.doi.org/10.1016/S0040-1951(01)00174-3.

Rey, P.F., Teyssier, C., and Whitney, D.L., 2009, The role of partial melting and extensional strain rates in the development of metamorphic core complexes: Tectonophysics, v. 477 , p. 135-144, http://dx.doi.org/10.1016/ j.tecto.2009.03.010.

Rivers, T., 1997, Lithotectonic elements of the Grenville Province: review and tectonic implications: Precambrian Research, v. 86, p. 117-154, http://dx.doi.org/ 10.1016/S0301-9268(97)00038-7.

Rivers, T., 2008, Assembly and preservation of lower, mid, and upper orogenic crust in the Grenville Province - Implications for the evolution of large hot longduration orogens: Precambrian Research, v. 167, p. 237-259, http://dx.doi.org/ 10.1016/j.precamres.2008.08.005.

Rivers, T., 2009, The Grenville Province as a large hot long-duration orogen insights from the spatial and thermal evolution of its orogenic fronts, in Murphy, J.B., Keppie, J.D., and Hynes, A.J., eds., Ancient Orogens and Modern Analogues: Geological Society, London, Special Publications, v. 327, p. 405-444, http://dx.doi.org/10.1144/SP327.17.

Rivers, T., 2012, Upper-crustal orogenic lid and mid-crustal core complexes: signature of a collapsed orogenic plateau in the hinterland of the Grenville Province: Canadian Journal of Earth Sciences, v. 49, p. 1-42, http://dx.doi.org/10.1139/ e11-014.

Rivers, T., 2015, Tectonic setting and evolution of the Grenville Orogen: An assessment of progress over the last 40 years: Geoscience Canada, v. 42, p. 77-124, http://dx.doi.org/10.12789/geocanj.2014.41.057.

Rivers, T., and Corrigan, D., 2000, Convergent margin on southeastern Laurentia during the Mesoproterozoic: tectonic implications: Canadian Journal of Earth Sciences, v. 37, p. 359-383, http://dx.doi.org/10.1139/e99-067.

Rivers, T., and Schwerdtner, W.M., 2014, New ideas on the post-peak development of the Central Gneiss Belt in the Muskoka region: Friends of the Grenville / Amis du Grenville field guide, 44 p. Available at: www.friendsofthegrenville.org.

Rivers, T., Culshaw, N., Hynes, A., Indares, A., Jamieson, R., and Martignole, J., 2012, The Grenville Orogen-A post-LITHOPROBE perspective. Chapter 3, in Percival, J.A., Cook, F.A., and Clowes, R.M., eds., Tectonic Styles in Canada: the LITHOPROBE Perspective: Geological Association of Canada Special Paper 49, p. $97-236$

Sanderson, D.J., and Marchini, W.R.D., 1984, Transpression: Journal of Structural Geology, v. 6, p. 449-458, http://dx.doi.org/10.1016/0191-8141(84)90058-0.

Schaubs, P.M., Carr, S.D., and Berman, R.G., 2002, Structural and metamorphic constraints on ca. 70 Ma deformation of the southern Valhalla complex, British Columbia: implications for the tectonic evolution of the southern Omineca belt: Journal of Structural Geology, v. 24, p. 1195-1214, http://dx.doi.org/ 10.1016/S0191-8141(01)00101-8.

Schlische, R.W., 1995, Geometry and origin of fault-related folds in extensional settings: American Association of Petroleum Geologists Bulletin, v. 37, p. 75-88.

Schwerdtner, W.M., 1970, Distribution of longitudinal finite strain in lenticular boudins and bending folds: Tectonophysics, v. 9, p. 537-545, http://dx.doi.org/10.1016/0040-1951(70)90004-1
Schwerdtner, W.M., 1977, Distortion and dilatation in paleostrain analysis: Tectonophysics, v. 40, p. T9-T13, http://dx.doi.org/10.1016/0040-1951(77)90062-2.

Schwerdtner, W.M., 1987, Interplay between folding and ductile shearing in the Proterozoic crust of the Muskoka-Parry Sound region of central Ontario: Canadian Journal of Earth Sciences, v. 24, p. 1507-1525, http://dx.doi.org/ $10.1139 / \mathrm{e} 87-148$.

Schwerdtner, W.M., and Klemens, W., 2008, Structure of Ahmic domain and its vicinity, southwestern Central Gneiss Belt, Grenville Province of Ontario (Canada): Precambrian Research, v. 167, p. 16-34, http://dx.doi.org/10.1016/ j.precamres.2008.07.002.

Schwerdtner, W.M., and Mawer, C.K., 1982, Geology of the Gravenhurst region, Grenville Structural Province, Ontario: Geological Survey of Canada, Current Research, Part B, Paper 82-1B, p. 197-207.

Schwerdtner, W.M., and van Berkel, J.T., 1991, The origin of fold abutments in the map pattern of the westernmost Grenville Province, central Ontario: Precambrian Research, v. 49, p. 35-59, http://dx.doi.org/10.1016/03019268(91)90055-F.

Schwerdtner, W.M., Waddington, D.H., and Stollery, G., 1974, Polycrystalline pseudomorphs as natural gauges of incremental paleostrain: Neues Jahrbuch fuer Mineralogie, Monatshefte, v. 314, p. 174-182.

Schwerdtner, W.M., Bennett, P.J., and Janes, T.W., 1977, Application of L-S fabric scheme to structural mapping and paleostrain analysis: Canadian Journal of Earth Sciences, v. 14, p. 1012-1032, http://dx.doi.org/10.1139/e77-094.

Schwerdtner, W.M., Klemens, W.P, Waddington, D.H., and Vertolli, V.M., 1998, LateGrenvillian horizontal extension and vertical thinning of Proterozoic gneisses, central Ontario: Geological Society of America Annual Meeting, Toronto, Canada, Field Trip Guide Number 14.

Schwerdtner, W.M., Riller, U.P., and Borowik, A., 2005, Structural testing of tectonic hypotheses by field-based analysis of distributed tangential shear: examples from major high-strain zones in the Grenville Province and other parts of the southern Canadian Shield: Canadian Journal of Earth Sciences, v. 42, p. 1927-1947, http://dx.doi.org/10.1139/e05-047.

Schwerdtner, W.M., Lu, S.J., and Landa, D., 2010a, S and Z buckle folds as shearsense indicators in the ductile realm: Field examples from the Grenville Province of Ontario and the Appalachians of South Carolina, in Tollo, R.P., Bartholomew, M.J., Hibbard, J.P., and Karabinos, P.M., eds., From Rodinia to Pangea: The Lithotectonic Record of the Appalachian Region: Geological Society of America, Memoirs, v. 206, p. 773-794, http://dx.doi.org/10.1130/ 2010.1206(30).

Schwerdtner, W.M., Lu, S.J., and Yang, J.F., 2010b, Wall-rock structure at the present contact surfaces between repeatedly deformed thrust sheets, Grenville Orogen of central Ontario: Canadian Journal of Earth Sciences, v. 47, p. 875-899, http://dx.doi.org/10.1139/E10-007.

Schwerdtner, W.M., Rivers, T., Zeeman, B., Wang, C.C., Tsolas, J., Yang, J., and Ahmed, M., 2014, Post-convergent structures in lower parts of the 1090-1050 Ma (early-Ottawan) thrust-sheet stack, Grenville Province of Ontario, southern Canadian Shield: Canadian Journal of Earth Sciences, v. 51, p. 243-265, http://dx.doi.org/10.1139/cjes-2013-0108.

Schwerdtner, W.M., Rivers, T., Tsolas, J., Waddington, D.H., Page, S., and Yang, J., submitted, Transtensional origin of multi-order cross-folds in a high-grade gneiss complex, southwestern Grenville Province, Canada: formation during post-peak gravitational collapse: Canadian Journal of Earth Sciences.

Selleck, B.W., McLelland, J.M., and Bickford, M.E., 2005, Granite emplacement during tectonic exhumation: The Adirondack example: Geology, v. 33, p. 781-784, http://dx.doi.org/10.1130/G21631.1

Slagstad, T., Culshaw, N.G., Jamieson, R.A., and Ketchum, J.W.F., 2004a, Early Mesoproterozoic tectonic history of the southwestern Grenville Province, Ontario: Constraints from geochemistry and geochronology of high-grade gneisses, in Tollo, R.P., Corriveau, L., McLelland, J., and Bartholomew, M.J., eds., Proterozoic tectonic evolution of the Grenville orogen in North America: Geological Society of America Memoirs, v. 197, p. 209-241, http://dx.doi.org/10.1130/08137-1197-5.209.

Slagstad, T., Hamilton, M.A., Jamieson, R.A., and Culshaw, N.G., 2004b, Timing and duration of melting in the mid orogenic crust: Constraints from U-Pb (SHRIMP) data, Muskoka and Shawanaga domains, Grenville Province, Ontario: Canadian Journal of Earth Sciences, v. 41, p. 1339-1365, http://dx.doi.org/10.1139/e04-068

Slagstad, T., Jamieson, R.A., and Culshaw, N.G., 2005, Formation, crystallization and migration of melt in the mid-orogenic crust: Muskoka domain migmatites, Grenville Province, Ontario: Journal of Petrology, v. 46, p. 893-919, http://dx.doi.org/10.1093/petrology/egi/004

Slagstad, T., Culshaw, N.G., Daly, J.S., and Jamieson, R.A., 2009, Western Grenville Province holds key to midcontinental Granite-Rhyolite Province enigma: Terra Nova, v. 21, p. 181-187, http://dx.doi.org/10.1111/j.1365-3121.2009.00871.x.

Soucy La Roche, R., Gervais, F., Tremblay, A., Crowley, J.L., and Ruffet, G., 2015, Tectono-metamorphic history of the eastern Taureau shear zone, Mauricie area, 
Québec: Implications for the exhumation of the mid-crust in the Grenville Province: Precambrian Research, v. 257, p. 22-46, http://dx.doi.org/ 10.1016/j.precamres.2014.11.012.

Streepey, M.M., Lithgow-Bertelloni, C., van der Pluijm, B.A., Essene, E.J., and Magloughlin, J.F., 2004, Exhumation of a collisional orogen: A perspective from the North American Grenville Province, in Tollo, R.P., Corriveau, L., McLelland, J., and Bartholomew, M.J., eds., Proterozoic tectonic evolution of the Grenville orogen in North America: Geological Society of America Memoirs, v. 197, p. 391-410, http://dx.doi.org/10.1130/0-8137-1197-5.391.

Teyssier. C., and Tikoff, B., 1999, Fabric stability in oblique convergence and divergence: Journal of Structural Geology, v. 21, p. 969-974, http://dx.doi.org/10.1016/S0191-8141(99)00067-X.

Teyssier, C., and Whitney, D.L., 2002, Gneiss domes and orogeny: Geology, v. 30, p. 1139-1142, http://dx.doi.org/10.1130/0091-7613(2002)030<1139:GDAO> 2.0.CO;2.

Thomson, S.N., Ring, U., Brichau, S., Glodny, J., and Will, T.M., 2009, Timing and nature of formation of the Ios metamorphic core complex, southern Cyclades, Greece, in Ring, U., and Wernicke, B., eds., Extending a Continent: Architecture, Rheology and Heat Budget: Geological Society, London, Special Publications, v. 321, p. 139-167, http://dx.doi.org/10.1144/sp321.7.

Timmermann, H., Jamieson, R.A., Culshaw, N.G., and Parrish, R.R., 1997, Time of metamorphism beneath the Central Metasedimentary Belt boundary thrust zone, Grenville Orogen, Ontario: accretion at 1080 Ma?: Canadian Journal of Earth Sciences, v. 34, p. 1023-1029, http://dx.doi.org/10.1139/e17-084

Timmermann, H., Jamieson, R.A., Parrish, R.R., and Culshaw, N.G., 2002, Coeval migmatites and granulites, Muskoka domain, southwestern Grenville Province, Ontario: Canadian Journal of Earth Sciences, v. 39, p. 239-258, http://dx.doi.org/10.1139/e01-076.

van der Pluijm, B.A., and Carlson, K.A., 1989, Extension in the Central Metasedimentary Belt of the Ontario Grenville: timing and tectonic significance: Geology, v. 17, p. 161-164, http://dx.doi.org/10.1130/0091-7613(1989)017 $<0161$ :EITCMB>2.3.CO;2.

Vanderhaeghe, O., 2009, Migmatites, granites and orogeny: Flow modes of partially molten rocks and magmas associated with melt/solid segregation in orogenic belts: Tectonophysics, v. 477, p. 119-134, http://dx.doi.org/10.1016/ j.tecto.2009.06.021.

Vanderhaeghe, O., Burg, J-P., and Teyssier, C., 1999, Exhumation of migmatites in two collapsed orogens: Canadian Cordillera and French Variscides, in Ring, U., Brandon, M.T., Lister, G.S., and Willett, S.D., eds., Exhumation Processes: Normal Faulting, Ductile Flow and Erosion: Geological Society, London, Special Publications, v. 154, p. 181-204, http://dx.doi.org/10.1144/ gsl.sp.1999.154.01.08.

Vanderhaeghe, O., Teyssier, C., McDougall, I., and Dunlap, W.J., 2003, Cooling and exhumation of the Shuswap Metamorphic Core Complex constrained by ${ }^{40} \mathrm{Ar} /{ }^{39} \mathrm{Ar}$ thermochronology: Geological Society of America Bulletin, v. 115, p. 200-216, http://dx.doi.org/10.1130/0016-7606(2003)115<0200:CAEOTS> 2.0.CO;2.

Venkat-Ramani, M., and Tikoff, B., 2002, Physical models of transtensional folding: Geology, v. 30, p. 523-526, http://dx.doi.org/10.1130/0091-7613(2002)030 $<0523$ :PMOTF $>2.0$.CO;2.

Waddington, D.H., 1973, Foliation and mineral lineation in the Moon River synform, Grenville structural province, Ontario: Unpublished MSc thesis, University of Toronto, Toronto, ON.

Ward, R., Stevens, G., and Kisters, A., 2008, Fluid and deformation induced partial melting and melt volumes in low-temperature granulite-facies metasediments, Damara Belt, Namibia: Lithos, v. 105, p. 253-271, http://dx.doi.org/10.1016/ j.lithos.2008.04.001.

Weinberg, R.F., and Hasalová, P., 2015, Water-fluxed melting of the continental crust: A review: Lithos, v. 212-215, p. 158-188, http://dx.doi.org/10.1016/ j.lithos.2014.08.021.

White, D.J., Forsyth, D.A., Asudeh, I., Carr, S.D., Wu, H., Easton, R.M., and Mereu, R.F., 2000, A seismic-based cross-section of the Grenville Orogen in southern Ontario and western Quebec: Canadian Journal of Earth Sciences, v. 37, p. 183-192, http://dx.doi.org/10.1139/e99-094.

White, I.R., and Crider, J.G., 2006, Extensional fault-propagation folds: mechanical models and observations from the Modoc Plateau, northeastern California: Journal of Structural Geology, v. 28, p. 1352-1370, http://dx.doi.org/10.1016/ j.jsg.2006.03.028.

Whitney, D.L., and Evans, B.W., 2010, Abbreviations for names of rock-forming minerals: American Mineralogist, v. 95, p. 185-187, http://dx.doi.org/10.2138/ am.2010.3371.

Whitney, D.L., Teyssier, C., and Heizler, M.T., 2007, Gneiss domes, metamorphic core complexes, and wrench zones: Thermal and structural evolution of the Niğde Massif, central Anatolia: Tectonics, v. 26, TC5002, http://dx.doi.org/ 10.1029/2006TC002040.

Whitney, D.L., Teyssier, C., Rey, P., and Buck, W.R., 2013, Continental and oceanic core complexes: Geological Society of America Bulletin, v. 125, p. 273-298, http://dx.doi.org/10.1130/B30754.1.

Wong, M.S., Williams, M.L., McLelland, J.M., Jercinovik, M.J., and Kowalkoski, J., 2012, Late Ottawan extension in the eastern Adirondack Highlands: Evidence from structural studies and zircon and monazite geochronology: Geological Society of America Bulletin, v. 124, p. 857-869, http://dx.doi.org/10.1130/ B30481.1.

Wynne-Edwards, H.R., 1972, The Grenville Province, in Price, R.A., and Douglas, R.J.W., eds., Variations in Tectonic Styles in Canada: Geological Association of Canada Special Paper No. 11, p. 263-334.

Yakymchuk, C., and Brown, M., 2014, Consequences of open-system melting in tec tonics: Journal of the Geological Society, v. 171, p. 21-40, http://dx.doi.org/ 10.1144/igs2013-039.

\section{Received April 2015}

Accepted as revised August 2015 